UNIVERSIDADE DE SÃO PAULO

FACULDADE DE ECONOMIA, ADMINISTRAÇÃO E CONTABILIDADE

CURSO DE PÓS GRADUAÇÃO EM CONTABILIDADE E CONTROLADORIA

\title{
CUSTEIO DAS ATIVIDADES DE NATUREZA AMBIENTAL
}

ORIENTADOR: Professor Doutor ELISEU MARTINS MAISA DE SOUZA RIBEIRO

Tese apresentada à Faculdade de Economia, Administração e Contabilidade da Universidade de São Paulo, para obtenção do título de Doutora em Contabilidade

SÃO PAULO

1998 
Reitor da Universidade de São Paulo

Professor Doutor Jacques Marcovith

Diretor da Faculdade de Economia, Administração e Contabilidade

Professor Doutor Denisard Cnéio de Oliveira Alves

Chefe do Departamento de Contabilidade e Atuária

Professor Doutor Reinaldo Guerreiro 


\section{ÍNDICE}

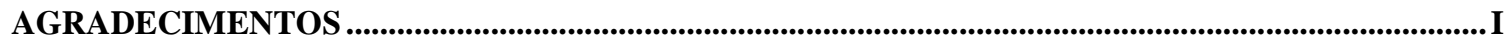

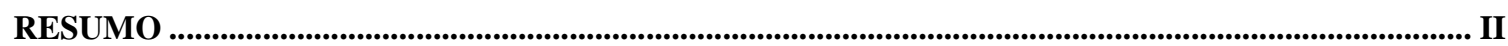

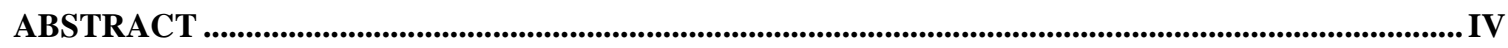

I - INTRODUÇÃ

II - EVOLUÇÃO DAS NECESSIDADES DE INFORMAÇÕES SOCIAIS .......................................... 9

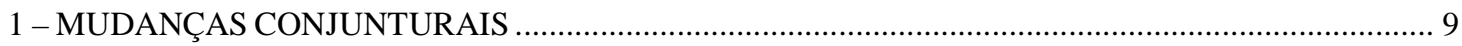

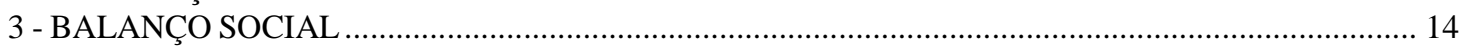

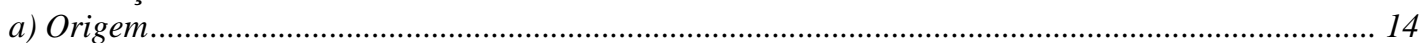

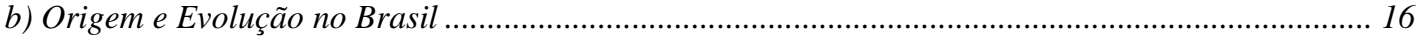

3.1 Demonstração do Valor Adicionado .............................................................................................. 20

3.2 Gestão de Recursos Humanos ........................................................................................................ 23

3.3 Interação com o Meio Ambiente ............................................................................................. 25

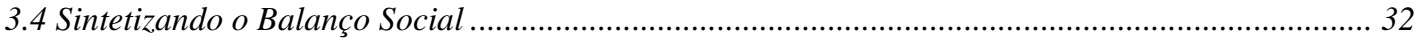

III - ITENS DE NATUREZA AMBIENTAL DO PATRIMÔNIO DAS COMPANHIAS ......................... 37

A - EVENTOS E TRANSAÇÕES COM IMPACTO NO PATRIMÔNIO DAS EMPRESAS .......................................... 37

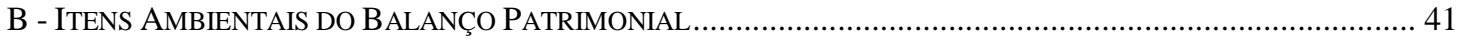

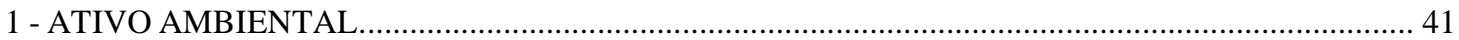

1.1 Gastos Ambientais com Características de Ativos Ambientais ........................................................ 43

1.1.1 Recursos Utilizados no Processo de Recuperação de Danos Ambientais ................................... 43

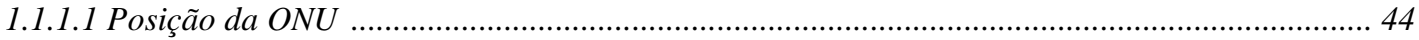

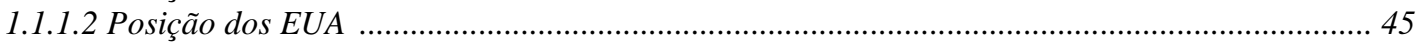

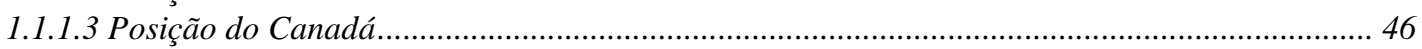

1.1.2 Gastos Posteriores ao Momento do Ingresso como Ativo ........................................................... 47

1.1.3 Gastos para Conservação de Recursos e Prevenção ou Redução de Danos................................ 48

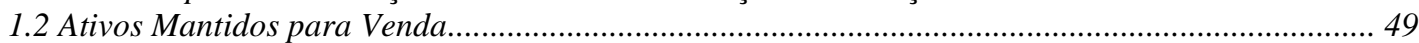

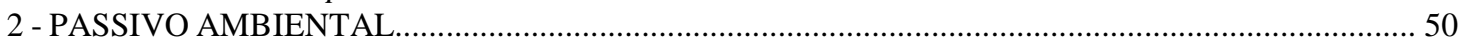

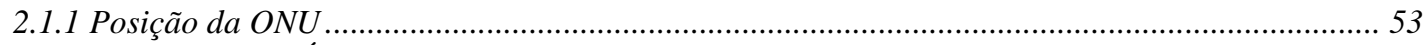

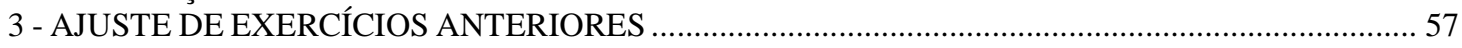

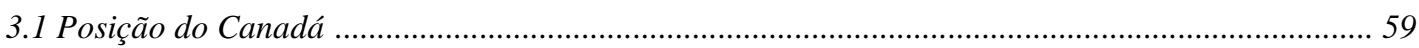

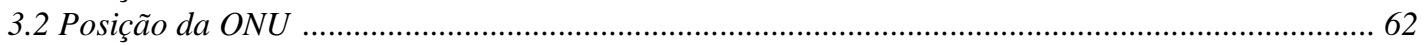

4 - CUSTOS/ DESPESAS/PERDAS ESPECÍFICOS DA ÁREA AMBIENTAL ................................... 63

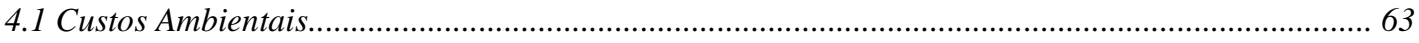

4.1.1 Custos Relacionados Diretamente aos Benefícios do Período em Curso...................................... 65

4.1.2 Custos Relacionados Indiretamente aos Benefícios do Período em Curso ................................. 66

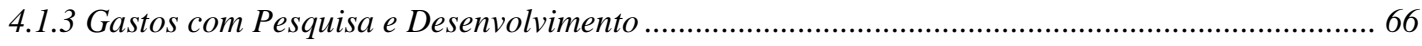

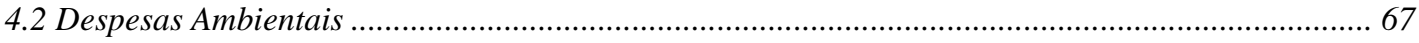

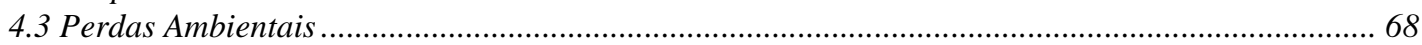

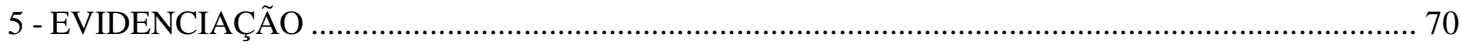

5.1 Políticas da Entidade Pertinentes ao Meio Ambiente................................................................. 71

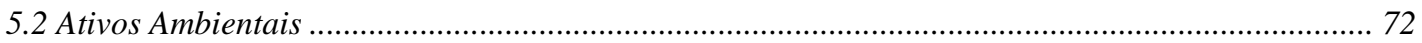

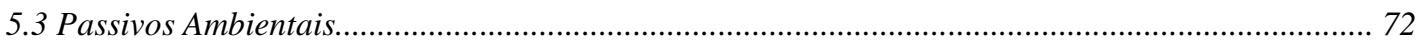

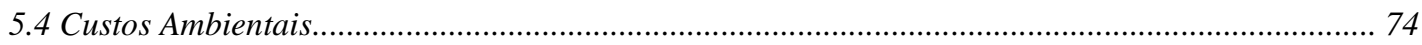

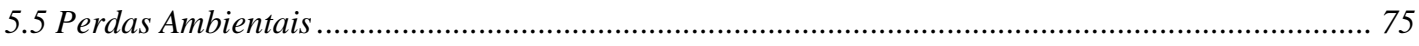

IV - GESTÃO AMBIENTAL E SEUS ASPECTOS ECONÔMICOS....................................................... 76

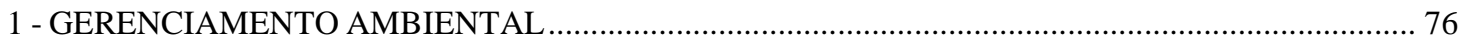


2 - ISO 14000 (E SUAS SUBSÉRIES) - SISTEMA DE GESTÃO AMBIENTAL (ABTN, 1996) E SUA INTERAÇÃO COM A GESTÃO ECONÔMICA DA EMPRESA....................................................... 80

2.1 Da Implementação, Manutenção e Controle ..................................................................................... 84

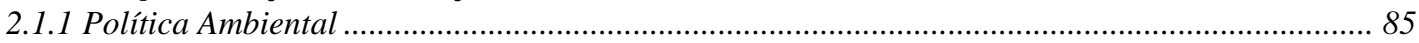

2.1.2 Planejamento ........................................................................................................................ 85

2.1.3 Implementação e Operação e o Planejamento Operacional e Execução..................................... 88

2.1.4 Verificação e Ação Corretiva e o Controle .................................................................................... 90

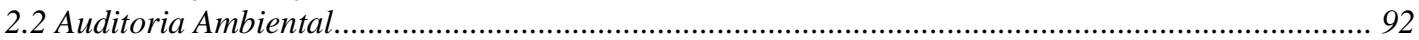

2.3 Análise Crítica pela Administração .......................................................................................... 92

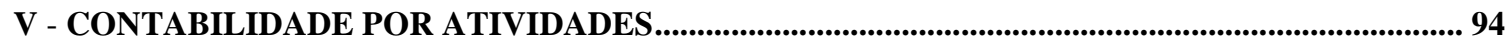

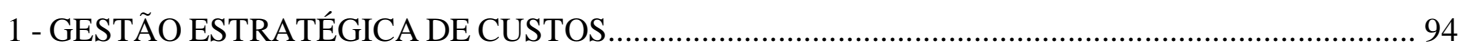

1.1 Custeio Baseado em Atividades ou Contabilidade por Atividades .............................................. 98

1.1.1 Centros de Custos .................................................................................................................... 101

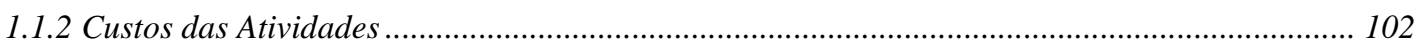

1.1.3 Direcionador de Custos ............................................................................................................ 103

1.1.2.2 Atribuição de Custos às Atividades .................................................................................. 105

1.1.3 Custos Pertinentes às Atividades .................................................................................................... 106

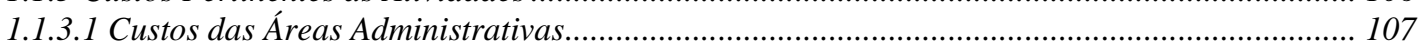

1.1.3.2 Amortização de Custos de Itens do Ativo Permanente ............................................................. 108

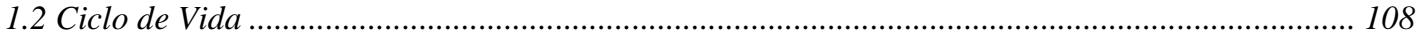

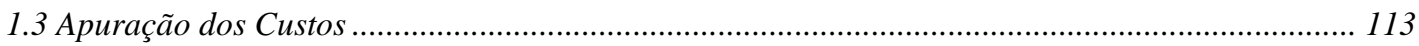

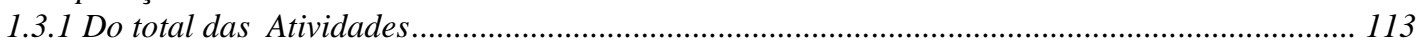

1.3.2 Do Processo ................................................................................................................................ 114

1.3.3 Do Direcionador de Custos de uma Atividade Especifica ....................................................... 114

1.3.4 Da Atividade Inerente à Produção de um Determinado Produto............................................... 114

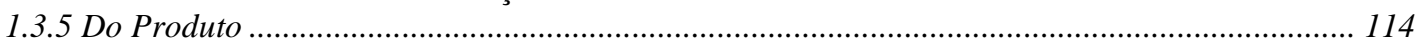

1.3.6 Do Centro de Custos................................................................................................................... 114

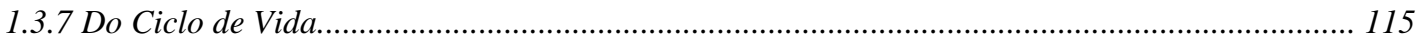

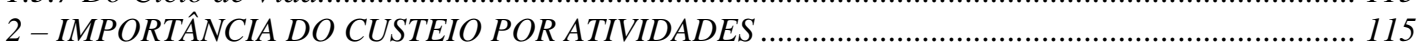

VI - SUGESTÕES PARA TRATAMENTO DOS GASTOS DE NATUREZA AMBIENTAL.............. 119

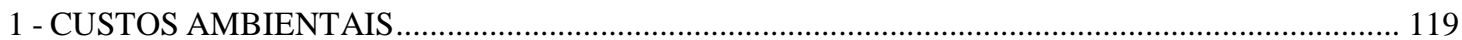

1.1 Identificando os Custos Ambientais ..................................................................................... 125

1.2 Direcionadores de Custos das Atividades de Controle, Preservação e Recuperação Ambiental... 126

1.4 Estrutura do Custeio para a Função de Controle Ambiental ....................................................... 127

2 - GESTÃO ESTRATÉGICA DOS CUSTOS AMBIENTAIS............................................................. 144

2.1 Avaliação de Resultados e de Desempenho............................................................................... 144

2.3 A Importância das Informações Econômico-Financeiras dos Aspectos Ambientais...................... 149

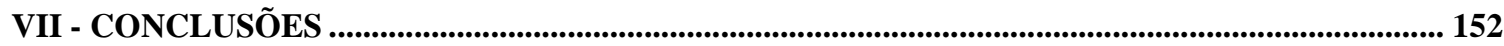

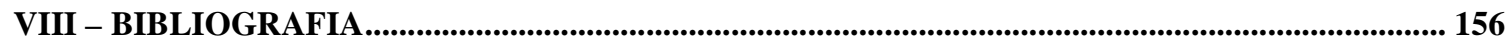




\section{AGRADECIMENTOS}

Ao amigo e professor Dr. Eliseu Martins, pela orientação, incentivo e ensinamentos, a minha sincera gratidão.

Aos professores do Departamento de Contabilidade e Atuária da Faculdade de Economia, Administração e Contabilidade da USP externo os meus agradecimentos pelos ensinamentos e colaboração, com especial menção para os professores Doutores Ariovaldo do Santos, Lázaro Plácido Lisboa, Marina Mitiyo Yamamoto, Masayuki Nakagawa e Nelson de Carvalho.

Não poderia deixar de dirigir o meu reconhecimento ao Professor Doutor Isak Kruglianskas, do Departamento de Administração, do qual obtive valiosas contribuições e sugestões.

Aos colegas do Curso de Pós-Graduação sou muito grata pelos valiosos incentivos e apoio.

A FIPECAFI - Fundação Instituto de Pesquisas Contábeis, Atuariais e Financeiras é também merecedora da minha gratidão pelo apoio e colaboração oferecidos durante todo o decorrer do trabalho. 


\section{RESUMO}

Os fatos econômicos, políticos, sociais e ambientais estão levando as empresas a se conscientizarem da responsabilidade social que cabe a cada uma delas.

Ao longo dos séculos, as atividades econômicas se desenvolveram sem muitas preocupações com fatores externos. Todavia, o elevado nível de degradação do patrimônio natural mundial acabou impulsionando a sociedade em geral (clientes, credores, governo, comunidade etc.) a exigir das empresas uma atuação mais responsável e enérgica no que tange à proteção ambiental.

Porém, dada a complexidade dos diversos processos operacionais existentes em cada companhia e, em muitos casos, a dimensão do parque operacional, aliados aos inúmeros tipos de resíduos poluentes passíveis de serem produzidos, os mecanismos de proteção ambiental são, via de regra, enormes e complexos, implicando gastos vultosos.

Tratando-se de fluxo de caixa ou de rentabilidade, qualquer investimento de ordem relevante deve merecer cuidadosos e rigorosos estudo e avaliação, devido ao fato de afetar a continuidade ou a forma de continuidade da organização.

Diante da inevitabilidade destes gastos, é mister que se adote uma metodologia estratégica para o gerenciamento de custos, visando à otimização dos recursos consumidos e à identificação de estratégias competitivas.

O custeamento das atividades realizadas para o controle, preservação e recuperação ambiental evidencia-se como a metodologia mais apropriada para identificar e apurar os custos ambientais, em função do nível de detalhamento do consumo de recursos. 
A metodologia tradicional da Contabilidade, de alocação de custos por meio de rateio, impossibilita a visualização dos fatores que realmente consomem os recursos econômicos e financeiros da empresa.

A gestão estratégica de custos ambientais é fundamental para o bom desempenho das empresas, como também para informar, adequadamente, aos usuários externos acerca da atuação da empresa, relativamente à proteção ambiental. Informar que investimentos estão sendo realizados não é o bastante; necessário se faz acrescentar dados sobre o sucesso destes investimentos, a evolução dos impactos de natureza ambiental sobre os resultados de cada período, assim como dos passivos ambientais da companhia. 


\section{ABSTRACT}

The economic, political, social and environmental events are making companies aware of its social responsabilities.

Over the centuries, economic activities have been carried out without much concern about external factors. However, with the increasing depletion of natural resources, society as a whole (customers, creditors, governments, communities etc) has been forced to demand more responsibility and determination on the part of companies, when it comes to environmental protection.

Nevertheless, given the complexity of the various operating processes used by each company and, quite often, the size of the industrial complex, and the numerous types of pollutants likely to be released, the environmental protection mechanisms ares usually huge and complex, and as such, extremely expensive.

As regards cash flow or profitability, any significant investment calls for careful, in-depth study and evaluation, because both affect an organization's ability to continue in business, or the way it does so.

Given the inevitability of such expenses, it is essential to adopt a cost management strategy aimed at optimizing resouces used and identifying competitive methods.

Costing activities involved in environmental control, preservation and recovery is the most suitable method for identifying and determining overall environmental costs, due to the level of detail required in breaking down resource expenditures.

Under the traditional accounting methods of appropriating cost on a prorated basis, it is impossible to identify factors that actually drain a company's economic and financial resources. 
The strategic management of environmental costs is essential no only for the companies good performance, but also to properly maintain external users abreast of the company's actions, as far as environmental protection is concerned. Simply informing about investments being made is not enough. More is needed, namely, provide additional data on the success of such investments, the way environmetal developments impact each period's results, and the company's environmental obligations. 


\begin{abstract}
The economical, political, social and environmental facts are leading the companies to the awareness of its own concerned responsabilities.

Through the centuries the economical activities have been developed without caring about external factors. However the increasing level of the world degradation of the nature wealth have been impelling the society, in general, (customers, creditors, governments, communities etc) to claim from enterprises a behavior more responsible and serious towards the environmental protection.
\end{abstract}

Although due to the complexity of the various existing operational processes in each company, and in many cases the operational site dimension associated to the numerous kinds of residual pollutants being produced the environmental protection devices are becoming, in general, very complex, of great dimension and very expensive.

Concerned flowing cash or profitability any relevante investment should deserve careful and meticulous evaluation studies due to that they may affect diret all continuity or kinds of the organization continuity.

Facing the inevitability of these expenditures it is imperative to adopt a strategic methodology towards the cost management aiming at the resources consumption optimization and the identification of the competitive strategies.

The bearing of the costs of the activities carried out to control, to preserve and to recuperate the environment is the best way to identify and to accurate the environmental costs due to the very detailed level of the resouces consumption. 
The traditionally methodology of Accounting that allocate costs by means of distribution makes impossible the disclosure of the events that really concur to the economical and financial resouces consumption of the companies.

The strategic management of environmental costs is so essential to a good performance of a company as well to inform appropriately the external users about the activities of the enterprise in relation to the environmental protection.

To disclosure the investments being carried out it is not enough. It is necessary to add more information about the successful results produced by these investments, i.e. the evolution of the impacts of environmental liabilities of the company. 


\section{I - INTRODUÇÃO}

A idéia de que a empresa é um sistema aberto que interage com o meio ambiente externo já vem de longa data. Esse meio ambiente era compreendido somente pelos fornecedores, instituições financeiras, governo e clientes. Todavia, especialmente nas últimas décadas, a ampla disseminação dos crescentes níveis de problemas gerados pela poluição e pelo esgotamento dos recursos naturais renováveis e não-renováveis fez com que o meio ambiente natural fosse compulsoriamente incluído nesta visão de meio ambiente externo com o qual as empresas interagem.

As pressões por melhoria da qualidade ambiental partiram dos ecólogos, ganharam as comunidades até chegarem às esferas governamentais, aos organismos internacionais, aos acordos, tratados e regulamentações do comércio internacional, às instituições de crédito mundial etc.

Se tudo isto não foi o gerador, foi o grande propulsor da consciência de responsabilidade social por parte das empresas. Se esta consciência não surgiu de forma espontânea, em face da fundamental importância que tem a forma de condução dos processos produtivos das atividades econômicas na manutenção e preservação do patrimônio natural mundial, surgiu de forma compulsória, pois as empresas precisam adotar mecanismos de proteção ambiental, uma vez que sua continuidade é altamente dependente:

- da manutenção e expansão do volume de clientes;

- de recursos externos, via instituições financeiras, via governo ou via fornecedores;

- da conservação do capital atual e captação de capitais adicionais de potenciais investidores;

- de estar em conformidade com as regulamentações governamentais; e

- da sua aceitabilidade pela comunidade na qual está inserida. 
Estes elementos - clientes, fornecedores, investidores, governo e comunidade -, dos quais a empresa depende, estão cada vez mais cônscios de que somente devem apoiar a continuidade de empresas que apresentem condições de lhes proporcionar o retorno esperado. Assim, os clientes estão interessados em ter à sua disposição produtos que possam ser consumidos sem lhes causar danos.

As linhas de crédito somente estão sendo concedidas (prática recente e crescente) para as empresas que tenham condições de operar de forma ambientalmente saudável. Esta postura tem sido incentivada por ações governamentais, no sentido de coibir o financiamento de atividades poluentes, bem como em reação à coobrigação por danos ambientais, imputados a algumas instituições de crédito, no caso, nos EUA. Estudos de Impacto Ambiental - EIA e Relatório de Impactos ao Meio Ambiente - RIMA passaram a compor o rol de requisitos obrigatórios para a concessão de empréstimos e financiamentos.

Os investidores estão cada vez mais cientes de que a má postura das empresas, em relação às questões ambientais, pode colocar em risco o retorno das aplicações de recursos.

Os governos, de forma geral, adotaram posturas mais rígidas quanto à permissão de abertura e continuidade de atividades econômicas potencialmente poluidoras, bem como quanto ao valor das penalidades (multas) para os transgressores das regulamentações ambientais e até sanções penais para os proprietários e administradores.

A sociedade, mais cônscia de seus direitos e poderes, tem se organizado para defender seus interesses, provocando, com isso, ações governamentais, tanto no sentido de interditar empresas agressoras do meio ambiente e bem-estar social como de divulgar aspectos negativos no que concerne ao desempenho destas empresas, fato que compromete a imagem, a reputação e os produtos por elas fabricados. 
Os recursos empregados pelas empresas sempre estiveram predominantemente concentrados na área produtiva propriamente dita; e em menor escala nas áreas administrativa e de vendas.

A problemática ambiental trouxe uma variável nova e bastante significativa em termos de volume financeiro, gerando, inevitavelmente, no momento atual, um fortíssimo impacto sobre o fluxo de caixa das empresas e conseqüentemente sobre a sua lucratividade, e que vem a ser a razão principal da grande resistência dos empresários em realizar investimentos na área de proteção ao meio ambiente.

Assim, em decorrência da forte disseminação da idéia de que "preservar é preciso" (preciso com a conotação de obrigatório), muitas companhias têm adotado instrumentos para gerenciamento ambiental. $\mathrm{O}$ grande desenvolvimento tecnológico tem auxiliado, sobremaneira, este processo; contudo, estas novas tecnologias exigiram e têm exigido gastos elevadíssimos.

A relevância dos gastos na área ambiental torna imperioso o adequado e detalhado gerenciamento destes, de forma a garantir a eficiência e eficácia da gestão econômica dos recursos disponibilizados para a continuidade da empresa, bem como no sentido de contribuir para o sucesso do sistema de gerenciamento ambiental em si. Contudo, como mensurá-los? Como identificar corretamente o consumo de cada produto no período e, mais ainda, durante o ciclo de vida destes? Como apurar o custo dos processos de proteção ambiental? A resposta a esta questões pode advir do estudo da relação custo/benefício dos gastos, que é de extrema importância na gestão econômica das organizações.

Apesar de se ter consciência do forte impacto que os gastos ambientais exercem sobre os custos empresariais, os instrumentos tradicionais da Contabilidade, quando os identificam, somente permitem seu custeio e repasse para o produto na forma de rateio, provocando impropriedades na distribuição de tais custos em função das arbitrariedades geradas por parâmetros subjetivos. 
A Contabilidade sofreu uma grande evolução desde o seu surgimento; contudo, esta evolução estacionou nas últimas décadas, deixando, portanto, de acompanhar as grandes revoluções tecnológicas ocorridas nas empresas neste período. Os princípios, práticas e procedimentos contábeis já não refletem, com bom nível de adequação, a mensuração da produção multivariada. Ignoraram os reflexos da inversão entre os custos diretos e indiretos, bem como a significativa elevação dos gastos com marketing e distribuição dos produtos, provocada pelo grande aumento do número de concorrentes.

Não obstante, surgiu, na década de 80, a Contabilidade por Atividades, que procura inovar os instrumentos da Contabilidade para custeamento dos recursos consumidos, com vistas a melhor subsidiar os gestores na condução dos negócios das companhias.

A Contabilidade por Atividades, ao custear as atividades, elimina considerável parte das arbitrariedades provocadas pelos custeamentos por meio de rateio e permite que se conheça o montante de gastos ambientais necessários à elaboração dos produtos, à conclusão das atividades, o custo inerente à proteção ambiental incorrido durante todo o ciclo de vida do produto.

A luta concorrencial acirrada entre as empresas tem impulsionado o desenvolvimento de metodologias estratégicas para o gerenciamento de custos, e cuja finalidade é identificar pontos fracos, melhorar o processo produtivo, conhecer o ciclo de vida dos produtos, em especial sob os aspectos de consumo de recursos comparativamente aos benefícios gerados, objetivando a otimização e subsídio para o lançamento de novos produtos.

Essas informações são importantes à medida que enriquecem os subsídios para decisões de melhorias, reestruturação, descontinuidade de atividades, produtos, processo de trabalho etc, alavancando, com tudo isso, a posição da empresa no mercado em termos de competitividade. 
O objetivo básico deste trabalho é definir e discutir os gastos que podem ser classificados como custos ambientais; demonstrar que o sistema de custeio por atividades é o único sistema que se adequa à apuração de tais custos; e demonstrar a importância da gestão estratégica econômica dos gastos ambientais.

Isto é essencial porque todos recursos econômicos e financeiros, de ordem relevante, consumidos na operacionalização de uma empresa, devem ser rigorosamente administrados com vistas a garantir a sua continuidade, podendo, simultaneamente, ser de enorme interesse (direto ou indireto) para clientes, investidores, fornecedores, instituições financeiras, governo, organismos vinculados à proteção ambiental etc.

O método utilizado para o desenvolvimento do trabalho foi o dedutivo. A partir de pesquisas bibliográficas, no que tange aos impactos nocivos das atividades econômicas sobre o meio ambiente natural e social e no referente aos conceitos de responsabilidade social, concluiu-se sobre a necessidade de se utilizar uma metodologia de custeio de gastos e de estratégia de custos ambientais. Os estudos sobre as formas de custeio existentes demonstraram que o sistema de Contabilidade por Atividades é uma metodologia que possui todas as características necessárias para a correta e precisa identificação e mensuração dos gastos de natureza ambiental, sendo de extrema validade para a gestão econômica dos recursos aplicados na área ambiental, para um desempenho consistente e lógico da própria área de gestão ambiental, e, ainda, para a obtenção de preciosos subsídios para a avaliação da responsabilidade social da empresa, tanto para fins internos como também externos.

As pesquisas de campo foram inviabilizadas porque os dados requeridos envolvem aspectos sigilosos das estratégias das empresas. Nas várias entrevistas realizadas em empresas que possuem características altamente poluentes, diretores, administradores e gerentes admitem que já implantaram (ou estão em processo de implantação) sistemas de gestão ambiental, sendo estes sistemas vinculados à alta administração devido a sua importância econômica e social. Ademais, dizem que mantêm controles específicos para os 
gastos na área ambiental, sendo que algumas os restringem aos investimentos em bens de natureza permanente, e outras o fazem, somente, para os gastos relativos a consumo imediato.

De acordo com as particularidades do processo operacional, ou do segmento econômico, os gastos inerentes ao gerenciamento ambiental podem ocorrer antes, durante ou após o processo operacional, nas três fases ou em apenas duas delas.

Sabe-se que com a captação de recursos no mercado internacional, de forma geral, principalmente a emissão de títulos na Bolsa de Valores de Nova Iorque, tem exigido das empresas relatórios circunstanciados sobre suas atividades e estado patrimonial, emitidos por empresas e profissionais especializados. Para a elaboração de tal parecer, estas empresas e profissionais fazem uma análise pormenorizada de todos os aspectos econômicos, financeiros e físicos que estejam afetando, ou poderão vir a afetar, a situação patrimonial da companhia em apreço. Neste contexto, certamente as variáveis de natureza ambiental também são incluídas nestes pareceres, se forem relevantes.

O resultado desse detalhado trabalho surpreende, muitas vezes, os próprios proprietários, administradores e gerentes das companhias, que nem sempre conseguem manter um controle total sobre todos os riscos inerentes ao negócio que conduzem.

Esses trabalhos recebem a denominação inglesa de "Due Diligencies". Há pouquíssimas empresas e profissionais credenciados para realizá-los. O registro minucioso de todos os fatos, eventos e transações que subsidiam o parecer final é de propriedade exclusiva destas empresas. Seu repasse à empresa contratante (e analisada) somente ocorre se houver previsão no contrato do trabalho.

Ambos, registro dos detalhamentos e parecer final, são sigilosos. Apesar de admitir a existência destes documentos (tanto a contratada como a contratante), as empresas não 
permitem sua divulgação ao público, fato este que eliminou mais uma das alternativas de pesquisa de campo para subsidiar o desenvolvimento deste trabalho.

Assim sendo, o seu desenvolvimento teve que se restringir aos aspectos teóricos das diretrizes básicas que tratam do gerenciamento e custeamento dos custos ambientais.

Com isso, não é possível saber quais e quantas empresas estão adotando sistema de custeio específico para controle dos custos ambientais. Pouquíssimas empresas divulgam o montante de gastos incorridos na área ambiental, e as que o fazem não utilizam formas sistematizadas e consistentes com as demais informações econômico-financeiras sobre a empresa como um todo. Contudo, a relevância do tema e dos montantes envolvidos exigem estudos e controles específicos.

As barreiras que podem ser colocadas para o empreendimento de tais estudos e implementação dos controles necessários são devidas às resistências às mudanças, muitas vezes sob a alegação de aumento de custos. Entretanto, o controle dos custos ambientais, apesar de exigir altos investimentos, tem como característica fundamental a de assegurar a continuidade das empresas, de reduzir gastos e contribuir para a otimização dos resultados empresariais, além de permitir, no médio e longo prazos, a compatibilização entre a postura da empresa e o que é ambientalmente exigido.

Inicialmente, serão abordados os aspectos relativos à responsabilidade social, apontando o Balanço Social como instrumento de prestação de contas da empresa para a sociedade em geral (Capítulo II). Em seguida, tratar-se-á dos itens de natureza ambiental incluídos nos patrimônios das companhias (Capítulo III). Prosseguindo, serão apresentadas algumas premissas básicas do gerenciamento ambiental, à luz da Norma ISO 14000 (e suas subséries), evidenciando os aspectos econômicos relativos ao mesmo (Capítulo IV). A etapa seguinte será dedicada a uma breve revisão da literatura, no tocante às premissas básicas da Contabilidade por Atividades (Capítulo V). A gestão econômica ambiental, por meio da aplicação dos conceitos da Contabilidade por Atividades à Gestão Ambiental, será 
objeto do Capítulo VI. O trabalho encerra com a apresentação das conclusões (Capítulo VII). 


\section{II - EVOLUÇÃO DAS NECESSIDADES DE INFORMAÇÕES SOCIAIS}

Este capítulo descreve a evolução dos tipos de informações prestadas pelas empresas à sociedade, o fim a que se destinam e a caracterização e necessidades de seus usuários. Demonstra, também, a utilidade do Balanço Social para a evidenciação da responsabilidade social das companhias.

\section{1 - MUDANÇAS CONJUNTURAIS}

A dinâmica e a complexidade da economia e da política mundial têm sofrido profundas alterações ao longo do tempo. Tem-se observado, nas últimas décadas, grandes transformações, sobretudo nas grandes potências, que têm provocado mudanças radicais nas áreas política, econômica e social, internas e externas. São exemplos disso: a grande reviravolta na economia japonesa para superar os prejuízos sofridos na Segunda Grande Guerra Mundial; a lamentável e longa Guerra do Vietnã; a reunificação da Alemanha, com a "queda do muro de Berlim"; a derrubada do partido comunista na ex-União Soviética; a catastrófica guerra entre Irã e Iraque, que gerou prejuízos gigantescos de natureza econômica, social e, notadamente, ambiental; o surgimento da União Européia e do MERCOSUL; a ECO 92, e outros tantos fatos que contribuíram para a união e interação política, econômica e social dos vários países do Planeta.

À medida que estas transformações ocorriam, o relacionamento econômico entre os vários países tornou-se cada vez mais intenso, derrubando os obstáculos provenientes das fronteiras e das distâncias. Além da cooperação social nos flagelos das guerras e conflitos, presenciou-se a expansão do mercado de consumo e, em muitos casos, a eliminação das "reservas de mercado", barreiras tarifárias e alfandegárias.

A abertura do mercado externo contribuiu para o acirramento da concorrência interna. A população se conscientizou, se uniu e passou a interferir na condução da política e economia, não só local, mas, também, em nível mundial, por meio de manifestações de 
repúdio a algumas condutas governamentais, bem como a empresas que inescrupulosamente auferiam lucros à custa de prejuízos sociais.

O desenvolvimento tecnológico, sobretudo das tecnologias de informação, o aprimoramento do nível de exigência, a quantidade de empresas no mercado e o poder econômico e político são alguns dos fatores que conduziram à formação de grupos voltados à defesa de interesses sociais, políticos e econômicos comuns, surgindo, entre outros mecanismos de defesa no plano político-econômico, as "barreiras alfandegárias".

No rol de preocupações relativas à condução das atividades econômicas inseriu-se a opinião pública sobre a empresa e o produto.

O produtor, que antes se colocava como "normatizador" das regras do mercado, produzindo na quantidade e com a qualidade que lhe fosse conveniente e ignorando a opinião do seu consumidor, mudou sua postura em função da inversão de papéis, pois, na atualidade, o cliente é quem define regras, padrões e qualidade, dado que suas opções são amplas e variadas, tanto no que tange à qualidade como no relativo ao onde, quanto, por quanto e de quem comprar.

Os custos da ineficiência não mais podem ser repassados ao preço do produto - a empresa deverá absorvê-los, enquanto não conseguir eliminá-los, via processo de adaptação e melhoria do processo produtivo, pois o preço é determinado pelo mercado, mais especificamente, pela combinação de forças entre clientes e concorrentes.

Comprar ou vender no mercado externo pode demandar o mesmo tempo e gastos consumidos nas transações internas, não só graças à expansão e melhoria dos meios de transporte, mas, principalmente, aos significativos avanços dos meios de comunicação: telefone, fax, internet etc. 
Os padrões de qualidade surgiram para ajustar a crescente produção, tomando como base os parâmetros das necessidades dos clientes e dando origem à ISO 9000, que trata dos padrões de qualidade de produtos e serviços em nível internacional. Dos exportadores, passou-se a exigir a implementação de tais padrões de qualidade. Posteriormente, surgiu a ISO 14000, estendendo as exigências no nível de qualidade para o processo de produção, impactos gerados antes, durante e depois do processo produtivo, interna e externamente, tendo como foco principal a qualidade do meio ambiente.

Empresas de todo o mundo se ajustaram, ou estão em processo de ajustamento, com vistas à continuidade, expansão e manutenção no mercado, agora internacional, que exige produtividade, eficácia, eficiência, racionalização, agilidade e qualidade técnica e ambiental.

Adaptar-se a todas estas mudanças, melhorar o processo produtivo, implementar qualidade ambiental não basta; necessário se faz demonstrar o que está sendo feito. A globalização das atividades econômicas, o fator concorrencial, a vasta gama de opções que têm os consumidores, os investidores, os fornecedores de linhas de crédito, o governo, enfim todos aqueles que têm interesse na continuidade da empresa exigem que a transparência das operações e conduta das empresas sejam o alvo de grande importância e preocupação, ou seja, a comunidade externa adquiriu grandes poderes, deixando as empresas em situação de grande vulnerabilidade. Por isso, agir certo, demonstrar que está agindo certo é uma questão fundamental.

As demonstrações contábeis representam o principal canal de comunicação entre a sociedade e a empresa. Por meio destas, a empresa procura prestar contas à comunidade, com quem interage, sobre sua conduta e estado patrimonial. 


\section{2 - EVOLUÇÃO DAS INFORMAÇÕES CONTÁBEIS ${ }^{1}$}

As demonstrações contábeis surgiram da necessidade de o proprietário ou gestor da atividade econômica controlar, avaliar e analisar a situação patrimonial e desempenho de seu negócio, provavelmente nas formas mais rudimentares possíveis.

Junto com a expansão das empresas, surgiram as figuras dos fornecedores e dos banqueiros, os quais exigem prestação de contas sobre a Entidade e sobre seu desempenho como forma de obter subsídio para a concessão de créditos à mesma. Esta "prestação de contas" veio se concretizar nas demonstrações contábeis, já em forma bem mais aprimorada do que o era anteriormente.

O governo, na sua tarefa e anseio de abastecer os cofres públicos, vê com o tempo, nas demonstrações contábeis, o instrumento adequado para controlar ou, especificamente, para conhecer sua base de arrecadação, instituindo-as como documento oficial e obrigatório às empresas.

$\mathrm{O}$ alto custo do capital obtido nas instituições financeiras e a crescente necessidade de recursos para acompanhar as exigências do mercado, quantitativa e qualitativamente, fazem com que as empresas se abram às participações de terceiros.

Surge então a figura dos novos sócios, aqueles investidores que estavam interessados em ganhar, sem as preocupações da rotina diária do gerenciamento de um negócio. O custo do capital obtido via investidores era bem menor do que o obtido por meio dos financiamentos bancários, além de ser baseado no resultado alcançado pela empresa em cada período. Novamente, as demonstrações contábeis foram alvo de refinamento, com a finalidade de informar aos novos proprietários a situação econômico-financeira e de desempenho da companhia.

\footnotetext{
${ }^{1}$ MARTINS, Eliseu - Anotações sobre a palestra proferida em 23/09/97 - "BALANÇO SOCIAL: Uma Idéia Viva", promovida pela JCA Treinamento Empresarial, em São Paulo.
} 
Concomitantemente a esta mudança de cenários e à multiplicação dos interessados nas informações sobre a situação patrimonial e o desempenho da empresa, os princípios, critérios, práticas e metodologias utilizados pela Contabilidade surgiram e se aperfeiçoaram. Não só para melhor refletir a real situação econômico-financeira da Entidade, mas também para que o usuário pudesse entender a situação refletida, comparar a evolução do negócio no decorrer do tempo, comparar empresas, analisar comportamento de segmentos econômicos e de economias locais.

A ênfase era sobre o Capital, representado pelos recursos provenientes dos credores e investidores, além do fisco, que é visto como uma fonte de consumo de recursos, e para os quais não há um retorno preciso.

Os empregados foram vistos, durante muito tempo, simplesmente como recursos à disposição da empresa, devendo a esta total obediência e tendo que se submeter a todas e quaisquer condições de trabalho oferecidas, uma vez que estavam sendo remunerados, e havia, muito mais do que hoje, escassez nas alternativas de trabalho. Com o tempo, alguns trabalhadores se conscientizaram dos excessos a que eram submetidos, de seus direitos, e passaram a disseminar suas idéias, surgindo então as entidades sindicais e associações de classe. O empresário entendeu, ao longo do tempo, que é mais estratégico trabalhar com o apoio dos empregados do que os tendo como opositores. A produtividade, eficiência e eficácia melhoram sobremaneira com o apoio destes. Para evidenciar os resultados dos esforços dos funcionários, bem como os benefícios decorrentes de tais esforços, as demonstrações contábeis se mostram como um veículo adequado.

A sociedade em geral, consumidores diretos ou indiretos da produção, ganhou sua importância entre os gestores das atividades econômicas também com bastante esforço. A população teve de se conscientizar de que podia exigir qualidade: 
- dos produtos e serviços;

- no atendimento, não só no momento da compra, como também em eventuais insatisfações após a compra;

- de vida: os indivíduos têm que ser respeitados quanto aos seus direitos ao ar, água e solo saudáveis; devem ser privados da poluição sonora etc.

Oferecer benefícios ou, no mínimo, não proporcionar malefícios à sociedade passou a ser o comportamento politicamente correto para angariar sua simpatia. Novamente, o conjunto das demonstrações contábeis pode servir de instrumento para tornar público o desempenho e empenho da empresa, a tendência de seu comportamento e, por inferência, os efeitos sobre a população.

Desta forma, as demonstrações contábeis, que surgiram com e para um único usuário, possuem, atualmente, uma vasta gama de novos e diversificados usuários, ou seja, foram criadas para atender às finalidades internas de gerenciamento e, hoje, além dessa finalidade, atendem aos fins sociais, ainda que limitadas aos aspectos econômicofinanceiros. Sob forma padronizada, procuram servir às necessidades de todos eles, adaptando-se, na medida do possível, às mudanças na conjuntura social, econômica e política.

Presentemente, vê-se alguns movimentos da sociedade brasileira no sentido de ampliar as informações de natureza social incluídas nas demonstrações contábeis. É a idéia de tentar resgatar o Balanço Social.

\section{3 - BALANÇO SOCIAL}

\section{a) Origem}

O balanço social foi instituído na França em 1977 (TINOCO, 1980, p. 101), porém com uma visão mais restrita a recursos humanos. Com o tempo, ganhou uma abordagem mais ampla, contemplando, além dos dados relativos a recursos humanos, a questão ambiental e 
o valor agregado à economia do País. Tudo isto ocorreu a partir da compreensão da sociedade acerca de seus direitos, ou seja, de ser adequadamente compensada pelos esforços que despende na condução das atividades de uma empresa, de garantir a continuidade e qualidade de vida saudável, de exigir que os recursos utilizados pelo governo no incentivo de algumas atividades econômicas produza, efetivamente, benefícios para a comunidade.

Segundo o material fornecido no Seminário "Balanço Social - Participação $X$ Responsabilidade Empresarial" (ABAMEC NACIONAL, 1997, p. 2), o Balanço Social, ou, mais precisamente, “...a idéia de se divulgar as atividades sociais da empresa juntamente com o relatório sobre o seu desempenho econômico-financeiro...”, teve origem na década de 60, a partir de dois movimentos.

\section{- Movimento de Empresários Cristãos}

A encíclica papal "Mater et Magister", publicada em 1961, pelo Concílio Vaticano II, propunha que as empresas apresentassem um relatório social.

Tendo como base esta encíclica, grupos de dirigentes empresariais cristãos de diversos países, membros da UNIAPAC - Union Internacionale Chrétienne de Dirigeants d' Enterprise, com sede em Bruxelas - Bélgica, organizaram-se no sentido de "...demonstrar a dimensão social da empresa, em especial, da responsabilidade social de seus dirigentes..." (ABAMEC NACIONAL, 1997, p. 2), particularmente no que tange os fatores humanos: mão-de-obra e benefícios à população local. Foi por meio destes grupos que a idéia do Balanço Social chegou ao Brasil. 


\section{- Movimentação Pacifista}

Este movimento teve origem na organização da sociedade americana contra a Guerra do Vietnã, compreendendo o boicote aos produtos e às ações das companhias que contribuíam para a guerra.

“...A reação das empresas atingidas foi a divulgação sistematizada e pública de todas suas atividades sociais, em especial, suas interações com a sociedade (atividades comunitárias e filantrópicas)." (ABAMEC NACIONAL, 1997, p. 2)

\section{b) Origem e Evolução no Brasil}

A UNIAPAC é denominada, no Brasil, de ADCE - Associação dos Dirigentes Cristãos de Empresas, tendo sido constituída em 1961. Esta entidade emitiu, em 1974, o "Decálogo do Empresário Cristão", cujos princípios prevêem que a empresa tem uma função social, a qual se materializa por meio“...da promoção dos que nela trabalham e na comunidade na qual deve integrar-se." (ABAMEC NACIONAL, 1997, p. 3)

A ADCE organizou, em 1977, o seu $2^{\circ}$ encontro nacional, onde discutiu o Balanço Social da Empresa. Neste mesmo ano, uma delegação brasileira participou de assembléia anual da UNIAPAC, no México, apresentando discussões sobre "Balanço Social - Instrumento a Serviço da Empresa". (ABAMEC NACIONAL, 1997, p. 3)

Ainda na década de 70, membros da ADCE, sob a coordenação do Professor Ernesto Lima Gonçalves, publicaram o primeiro livro, e até agora único, sobre Balanço Social, o qual intitulou-se "Balanço Social da Empresa na América Latina", pela editora Pioneira, abordando alguns aspectos relativos à responsabilidade social das empresas. 
Em abril de 1980, a mesma ADCE promoveu, em São Paulo, o "Seminário Internacional de Balanço Social", contando com palestrantes da Alemanha, Argentina, Brasil, Chile, Colômbia, Espanha e Uruguai. ${ }^{2}$

Em 1980, o professor João Eduardo Prudêncio Tinoco apresentou sua dissertação de mestrado, na Faculdade de Economia, Administração e Contabilidade, da USP, sob o título "Balanço Social: Uma Abordagem Sócio-Econômica da Contabilidade", a qual abordava os aspectos socioeconômicos do Balanço Social, com ênfase nos recursos humanos. Em 1996, este mesmo autor apresentou sua tese de doutoramento intitulada: "Contribuição ao Estudo da Contabilidade Estratégica de Recursos Humanos".

A apostila do Seminário sobre Balanço Social, da ABAMEC (1997, p. 4), retrocitada, registra ainda algumas iniciativas pioneiras referentes à publicação do Balanço Social:

- 1984 - Balanço Social da empresa Nitrofértil - reconhecido como o primeiro publicado no Brasil;

- 1986 - "Balanço Social do Mercado de Capitais", patrocinado pelo CODIMEC Comitê de Divulgação do Mercado de Capitais;

- 1991 - primeira Demonstração do Valor Adicionado, publicada pela TELEBRÁS;

- 1992 - publicação da Demonstração do Valor Adicionado, pela extinta CMTC Companhia Metropolitana de Transportes Coletivos - e pelo Banespa;

- 1993 - primeira Demonstração do Valor Adicionado do Setor Bancário, elaborada pela FEBRABAN - Federação das Associações Brasileiras de Bancos.

Ainda, segundo o referido material, foi enviado ao Congresso Nacional, em 1991, pelo Deputado Valmir Campello, “...um anteprojeto propondo a publicação compulsória do Balanço Social pelas empresas...”, o qual nunca foi colocado em pauta para discussão e votação.

\footnotetext{
${ }^{2}$ Apostila do Seminário Internacional de Balanço Social. Promovido pela ADCE, em abril/1980, p. 1 - 3.
} 
Segundo MARTINS (GAZETA MERCANTIL, 1997, p. A-3), foi apresentado, em 1987, um projeto de lei para instituição do balanço social, pelo secretário-geral do Ministério da Justiça, José Paulo Cavalcante.

Em 1996, houve uma iniciativa do IBASE - Instituto Brasileiro de Análises Sociais e Econômicas, por meio de seu presidente, o sociólogo Herbert de Souza, com vistas a resgatar a figura do Balanço Social, idéia esta que deu origem ao Projeto de Lei n ${ }^{\circ}$ 3116/97, de autoria das Deputadas Marta Suplicy, Sandra Starling e Maria da Conceição Tavares, que tem por objetivo obrigar as empresas a publicar seu Balanço Social. De acordo com este Projeto de Lei (se aprovado), o balanço social deve conter dados sobre o faturamento, empregados (quantidade, remuneração, sexo, faixa etária e benefícios), encargos sociais e tributos pagos, investimentos em segurança, em meio ambiente, em benefícios à comunidade externa, à empresa etc.

Há que se ressaltar que o conteúdo da proposta lançada por aquelas deputadas tem base no modelo francês, e já circulava no Brasil, pelo menos desde 1977, mediante os trabalhos da ADCE. Um de seus membros, o professor Ernesto Lima Gonçalves (em co-autoria com Benoit Six) escreveu, em 1979 (GONÇALVES \& SIX, apud ABAMEC, 1997, p. 8), sobre o conteúdo do Balanço Social:

"A tarefa de procurar a definição do que medir poderá ser desenvolvida...mediante a determinação de alguns indicadores que possam retratar, de maneira objetiva, o nível em que, num determinado período de tempo, se desenvolveram, no âmbito da empresa, as iniciativas sociais, ou de que maneira repercutiram sobre a atividade da empresa. Assim, devem ser considerados, por exemplo, os programas de assistência médica, de alimentação e de capacitação, ou os planos previdenciários, as iniciativas educacionais e os sistemas de crédito, mas devem também ser examinados a rotatividade de pessoal, os índices de absenteísmo, a freqüência das reclamações trabalhistas, bem como a freqüência e a gravidade dos acidentes de trabalho." 
GONÇALVES (apud ABAMEC NACIONAL, 1997, p. 14) afirmou, em 1980:

"Numa tentativa de estruturação dos laços entre a empresa e a sociedade, poderíamos reuni-los em grupos: inicialmente os que se referem a características da própria empresa, como o ramo de sua atividade, seu efetivo, o volume de suas vendas, sua estrutura organizacional, a composição de seu capital, etc.; em segundo lugar, todos os aspectos relativos ao relacionamento interpessoal no seio da empresa e as relações entre esta e o pessoal; a seguir, as eventuais conseqüências da atividade da empresa sobre a deterioração do meio ambiente; depois, os programas de investigação científica que ocasionalmente a empresa desenvolva; por último, atividades de utilidade pública de que ela eventualmente se encarregue."

Observa-se, assim, que a tentativa de implementação do balanço social no Brasil não é nova; consequientemente, os problemas que deram origem às novas tentativas de instituição da lei são antigos e continuam os mesmos, porém, em níveis de gravidade que chegam a patamares mais alarmantes.

Em agosto de 1997, a Comissão de Valores Mobiliários - CVM - colocou a discussão sobre a implementação do balanço social e sua obrigatoriedade em audiência pública, a fim de obter elementos para oficializar sua posição sobre o assunto. Contudo, tratando-se de tema polêmico e de difícil consenso, a CVM não obteve um retorno que pudesse ser considerado majoritário. Assim sendo, a instituição do balanço social no Brasil permanece na dependência de decisão do Congresso Nacional.

Relançada a idéia do balanço social, e dada a situação sócio-econômica-ambiental, alguns seminários têm sido promovidos para divulgar e discutir o assunto. $\mathrm{O}$ aspecto mais polêmico é a questão da obrigatoriedade; enquanto alguns entendem que é necessário impor a publicação, outros acham que deveria ser deixada, ao encargo das empresas, a decisão de publicar ou não tais informações. 
A empresa que muitas vezes teve como objetivo final e maior o lucro dos proprietários, nos dias atuais, além desse objetivo, também importante no sentido de assegurar o capital necessário à condução das atividades, precisa incluir entre suas metas a satisfação da sociedade (no sentido amplo: investidores, clientes, governo, empregados, fornecedores e população em geral) em termos de qualidade do produto e do meio ambiente, antes, durante e depois do processo produtivo, segurança e condições adequadas no ambiente de trabalho, além de quantidade e preços.

Como se pôde verificar, no seu início o balanço social era visto num sentido mais restrito, limitando-se a abordar aspectos relativos à força de trabalho empregada pela empresa. Com o decorrer do tempo, passou-se a discutir, como elemento da responsabilidade social da empresa e, por conseguinte, do Balanço Social, os aspectos relativos à interação da empresa com o meio ambiente natural. Por fim, a contribuição efetiva da empresa ao meio social veio a ser demonstrada pelo Valor Adicionado à economia local.

Em síntese, o Balanço Social, no sentido mais amplo, deve refletir toda a responsabilidade social da empresa para com a sociedade, contendo informações sobre:

- o Valor Adicionado pela empresa à economia e à sociedade;

- a gestão de recursos humanos: benefícios proporcionados à mão-de-obra empregada;

- sua interação com o meio ambiente: impactos e benefícios de suas atividades sobre o meio natural, bem como os efeitos negativos deste meio sobre seu patrimônio.

\subsection{Demonstração do Valor Adicionado}

As empresas captam, do meio onde estão sediadas, os recursos necessários ao desenvolvimento de suas atividades. Estes recursos são os mais variados possíveis, compreendendo, entre outros: os recursos financeiros, seja dos acionistas, seja de terceiros; os insumos e serviços adquiridos de seus fornecedores, a mão-de-obra necessária à 
operacionalização de suas atividades; os serviços de utilidade pública, como água, energia elétrica, serviços de saneamento, de urbanização etc.

O consumo destes recursos é normalmente evidenciado por meio da Demonstração de Resultados, juntamente com as receitas auferidas no mesmo período sem, contudo, informar os benefícios agregados pela empresa, limitando-se a discriminar os benefícios gerados para os acionistas. A Demonstração do Valor Adicionado objetiva evidenciar os benefícios proporcionados em prol da comunidade como um todo. Informa quanto a empresa adicionou, no período, aos recursos adquiridos de terceiros, e como distribuiu esse Valor Adicionado entre a remuneração do uso de capital de terceiros: juros e aluguéis, remuneração da mão-de-obra, impostos pagos ao governo, remuneração do capital próprio.

Nas palavras de MARTINS (GAZETA MERCANTIL, 1997, p. A-3) “...Trata-se, a Demonstração do Valor Adicionado, de uma explanação de como a empresa criou riqueza (valor de seu "output"- vendas de bens e serviços - deduzido dos bens e serviços adquiridos de terceiros) e como a distribuiu entre ...: fornecedores de capital, recursos humanos e governo. Vê-se, então, a parte da riqueza criada que cabe aos primeiros na forma de financiadores (via juros e aluguéis), de sócios (via dividendos e lucros retidos) e de detentores de tecnologia (via royalities); aos dos recursos humanos via seus salários, gratificações, honorários, participações nos resultados, etc. e, finalmente, ao governo via impostos, diretos e indiretos. Extraordinária forma de ver a função social da empresa, além de qual a sua parcela na criação da riqueza global do País, o PIB, em vez de só dar tanta ênfase apenas à linha final da demonstração do resultado tradicional, de interesse exclusivo dos proprietários."

DE LUCA (1996, p. 65), tratando da Demonstração do Valor Adicionado, em sua tese de doutorado, ressalta que:

"As empresas desempenham um importante papel social e econômico nas regiões onde atuam e dificilmente esse papel é representado nas demonstrações contábeis tradicionais - 
balanço patrimonial, demonstração do resultado, demonstração de lucros ou prejuízos acumulados, demonstração das mutações do patrimônio líquido e demonstração das origens e aplicações de recursos, acompanhadas de notas explicativas e do relatório da administração."

Prosseguindo, a autora enfatiza o grande diferencial proporcionado por esta demonstração: "Trata-se de uma visão diferente em termos de demonstrações contábeis. Em geral, as tradicionais demonstrações contábeis estão preocupadas em evidenciar para os investidores qual o lucro da empresa e como ele foi calculado. A demonstração do resultado do exercício, por exemplo, está mais voltada para um determinado tipo de usuário: o proprietário da empresa que quer conhecer o valor do seu lucro final. A demonstração do resultado do exercício avalia a parte da riqueza criada pela empresa (o valor adicionado) que se destina ao proprietário; é o enfoque do proprietário. E, para ele, os salários, juros, impostos etc. são tratados como despesas, pois na realidade representam reduções de sua parte da riqueza criada, ou seja, do seu lucro. A demonstração do valor adicionado vem evidenciar, além do lucro dos investidores, a quem pertence o restante da riqueza criada pela empresa."

Sendo o objetivo desta demonstração informar o montante de geração de riqueza por empresa, em contrapartida à aplicação dos recursos gerados, a consolidação de todas as demonstrações de valor adicionado poderia resultar no Produto Interno Bruto, excluídas as duplicidades de informações, desde que bem elaboradas e seguindo critérios homogêneos. Obviamente, isto somente seria possível mediante a Demonstração do Valor Adicionado de todos os agentes econômicos, ou seja, todas as empresas de fins lucrativos, não-lucrativos, governamentais e os profissionais autônomos.

Sob este ponto de vista, IUDÍCIBUS (apud DE LUCA, 1996, p. 92) argumenta que "em sua estrutura, a Demonstração do Valor Adicionado é muito parecida com o esquema de contas de renda nacional. ... Conceitualmente, todavia, se todas as atividades econômicas desenvolvidas no País fossem desenroladas em entidades que levantassem demonstrações a 
valor adicionado, ... a consolidação de tais demonstrações, excluídas as duplas contagens, já seria o próprio PIB, muito mais corretamente estimado do que atualmente."

\subsection{Gestão de Recursos Humanos}

GONÇALVES \& SIX (apud ABAMEC NACIONAL, 1997, p. 8) enfatizam a importância dos recursos humanos na continuidade da empresa: "Vale a pena lembrar aqui que essa entidade - a empresa - destinada à produção, à troca, à circulação de bens e/ou serviços nasce de um ato, uma iniciativa que só pode ser fruto da atividade de homens, destinada a atender a expectativas de outros homens. Por esse ato, reúnem-se, na estrutura da empresa, pessoas e coisas; estas, que são estéreis por sua própria natureza, tornam-se fecundas e

produtivas por ação das pessoas.... Por sua própria natureza, ela (a empresa) não se resume nos estoques acumulados, nem nos lucros contabilizados, mas consiste, formalmente, num complexo de atos humanos, dos quais estoques e lucros não são mais do que o resultado. Nem mesmo os espetaculares progressos da automação poderão modificar o fato de que nenhuma tarefa criadora se realiza, na vida da empresa, sem a vontade e a iniciativa de um homem."

Vinte anos depois, estas afirmações ainda refletem a realidade, e até com mais ênfase. Isto porque a sociedade se conscientizou, em uma escala muito mais ampla, dos seus direitos e do que pode exigir das empresas, tendo em vista, principalmente, o tempo que nela passa e a ela se dedica. GONÇALVES \& SIX (apud ABAMEC NACIONAL, 1997, p. 7) ressaltam ainda que a empresa é o "...ambiente onde cada homem deve poder realizar-se plenamente como pessoa, pela execução de seu trabalho."

A gestão de recursos humanos compreende todos os esforços no sentido de recrutar, organizar, manter, incentivar e treinar o corpo de colaboradores que serve à companhia. Algumas das informações pertinentes são: quantidade de empregos gerados, remuneração total oferecida, aproveitamento da mão-de-obra qualificada e disponibilizada pelo meio acadêmico, investimentos no aperfeiçoamento e especialização do corpo de colaboradores, 
custo da assistência médica e social e dos planos de aposentadoria proporcionados, custo com alimentação e transporte, faixa etária e sexo. Em alguns países, é mencionado inclusive dados quanto às minorias raciais. Aliás, este item está incluído na proposta de Lei lançada no Brasil.

Segundo Martins (GAZETA MERCANTIL, 1997, p. A-3), o "balanço de recursos humanos" traz informações “...sobre a composição da força de trabalho, nível educacional formal, treinamento, política de remuneração, produtividade e sua evolução, movimentação física, absenteísmo, assistências previdenciária, médica, social e outras, sexo, alimentação, transporte, ensino de línguas, preparação para a despedida, ampliação da capacidade de adaptação e outras atividades, etc."

Informações deste tipo são importantes para se conhecer a capacidade de absorção de mãode-obra do mercado; o nível de especialização e tipo de habilidades a que o meio acadêmico precisa se dedicar; o aperfeiçoamento do ensino nas redes pública e privada; os subsídios para melhoria dos serviços de assistência social e médica fornecidos pelo governo à população não contemplada pelas empresas e para atendimento da força de trabalho não priorizada por estas, como determinadas faixas etárias e sexo; e, também, para se ter informações acerca do poder de consumo dos empregados.

Na sua forma mais tradicional, essas informações serviriam para demonstrar o empenho da organização em maximizar sua produtividade, ao elevar sua mão-de-obra da mera condição de empregados assalariados para a de colaboradores. Em síntese, reflete parte da responsabilidade social da empresa para com aqueles que lhes serve, e sua contribuição para a melhoria das condições sociais e econômicas na região.

Segundo TINOCO (1997, p. 12):

"A Contabilidade e a Gestão Estratégica de Recursos Humanos tratam do reconhecimento das pessoas como recurso organizacional e estratégico, visando à sobrevivência e à 
continuidade das entidades no tempo, com o objetivo de serem competitivas, em busca da maximização do retorno de investimento em recursos físicos, tecnológicos e humanos."

TINOCO sugere que a Contabilidade, num sentido bastante avançado, deveria avaliar e registrar o valor do potencial dos recursos humanos. Isto porque:

"Envolve esta Contabilidade (a de recursos humanos) os custos incorridos por entidades para recrutar, selecionar, contratar, treinar e desenvolver ativos humanos. Incorpora, também, em decorrência da contratação, do treinamento, da formação e da conservação dos recursos humanos, o reconhecimento do valor que estes recursos proporcionam para as entidades e que precisam ser devidamente contabilizados, mensurados, analisados, avaliados e divulgados."

A prestação de informações quanto à forma e características de gestão dos recursos humanos foi, durante muito tempo, a única ótica que se tinha sobre o Balanço Social. Esta visão restringia a abrangência da responsabilidade social da empresa, tendo em vista todos os recursos que capta da sociedade.

\subsection{Interação com o Meio Ambiente}

Ao captar, do meio ambiente, recursos naturais renováveis ou não, a empresa está se utilizando do patrimônio da humanidade. Tais recursos, quando não consumidos totalmente e devolvidos de forma deteriorada, afetam negativamente o patrimônio natural, via redução do volume de água potável, do nível de qualidade do ar, da diminuição da área de terras habitáveis ou cultiváveis, restringindo, portanto, as condições de vida das gerações futuras, e até mesmo da presente. E, quando consumidos total e indiscriminadamente, provocam sua extinção. 
As empresas estão sendo cada vez mais pressionadas, por diversos segmentos, para melhorar e aperfeiçoar seus processos produtivos, no sentido de reduzir as agressões ao meio ambiente.

Estas pressões estão refletidas em fatos e atos, como a seguir relacionados:

- As legislações, em nível mundial, que tratam da obrigatoriedade de acondicionamento dos resíduos tóxicos, são relativamente recentes e objetivam a redução da agressão ao meio ambiente. A implementação de tais legislações consome relevante soma de recursos, dado que os meios necessários para tal acondicionamento exigem, pela própria natureza, tecnologias avançadas e caras.

- Os produtos biodegradáveis exigiram o estudo e desenvolvimento de tecnologias não agressivas à natureza, resultando na substituição de elementos do processo produtivo (ou na inclusão de insumos adicionais) e na redução do teor tóxico das águas residuais do processo produtivo.

- As exigências de tratamento dos resíduos tóxicos, antes do lançamento destes ao meio ambiente, têm resultado no desenvolvimento e aquisição de tecnologias caríssimas e, em alguns casos, em reutilização dos resíduos tratados no próprio processo produtivo, como no caso das águas residuais que são tratadas e utilizadas para a geração de energia interna.

- Os Estudos de Impacto Ambiental - EIA's e os Relatórios de Impacto Ambiental RIMA's são documentos que ganharam ampla utilização em nível mundial. A autorização para constituição e funcionamento das empresas está condicionada à apresentação destes aos órgãos técnicos governamentais responsáveis. De acordo com o "Protocolo Verde" - acordo firmado entre o IBAMA - Instituto Brasileiro do Meio Ambiente e dos Recursos Naturais Renováveis, o BNDES - Banco Nacional de Desenvolvimento Econômico e Social, o Banco Central, o Banco do Brasil, a Caixa 
Econômica Federal, o Banco do Nordeste do Brasil e o Banco da Amazônia - as empresas que pleitearem financiamento nas referidas instituições devem apresentar o EIA e o RIMA. ${ }^{3}$ Instituições internacionais que têm linhas de crédito para projetos na área ambiental, como o BID (Banco Interamericano de Desenvolvimento), o BIRD (Banco Mundial), o Fundo Nakasone, do Japão e a Agência Alemã de Cooperação (GTZ), também exigem tais documentos, apesar de a concessão dos recursos ser realizada via intermediação do governo. (DOWELL, 1997, p. 297)

- As sanções penais aos administradores e proprietários de empresas (inclusive no Brasil, a partir de fevereiro de 1998 - Lei 9.605) estão comprometendo a liberdade e os bens particulares destes.

Em algumas situações, os investimentos adicionais (pesquisa, desenvolvimento e insumos), são compensados com economias de custos para as empresas e para o patrimônio natural humano.

- A reciclagem, por exemplo, envolve economia de matéria-prima e, portanto, dos recursos naturais. O papel reciclado, por exemplo, substitui a celulose e, além de ser considerado mais barato, reduz os desmatamentos e a erosão dos solos.

Obviamente, a elaboração destes documentos implicam o consumo significativo de recursos e tempo.

As informações quanto aos investimentos realizados na área ambiental, as obrigações decorrentes de falhas na interação com o patrimônio natural e o consumo de recursos utilizados para reduzir e corrigir os impactos adversos servem para orientar o público externo quanto à postura e preocupação da empresa com a questão ambiental e, por conseguinte, com a sociedade presente e futura. Servem, também, para evidenciar os riscos de descontinuidade pela desconsideração dos aspectos ambientais, riscos estes que podem

${ }^{3}$ MINISTÉRIO DO MEIO AMBIENTE, DOS RECURSOS HIDRÍCOS E DA AMAZÔNIA LEGAL - 
estar refletidos no desinteresse dos investidores em continuar na empresa, na perda e/ou redução de confiabilidade de instituições financeiras e fornecedores, perda de mercado para outras empresas, cuja produção seja considerada ambientalmente mais saudável ou pela intervenção governamental.

Vale ainda ressaltar que a vulnerabilidade da empresa ante o meio ambiente - efeitos adversos da poluição, enchentes causadas por alteração do meio natural, assoreamento de rios etc - também é de interesse fundamental para aqueles que empregam recursos na companhia ou têm benefícios na sua continuidade.

As informações na área ambiental podem ter, além da natureza financeira, a quantitativa, refletidas no volume de resíduos poluentes produzidos, na sua evolução no tempo, comparativamente aos patamares permitidos pela legislação local e/ou no volume de produtos elaborados. O controle do consumo de energia elétrica e demais recursos nãorenováveis também estão associados ao controle ambiental, o que poderia ser avaliado, entre outras formas, mediante o nível de consumo ao longo dos períodos. Os dados físicos sobre os programas de melhorias e aperfeiçoamento constituir-se-iam, enfim, nas informações de natureza qualitativa sobre o empenho da organização.

Em 1996, o IBRACON - Instituto Brasileiro de Contadores publicou o NPA 11 estabelecendo ( $p .3)$ "os liames entre a Contabilidade e O Meio Ambiente...", além de incumbi-la de “...participar dos esforços em favor da defesa e proteção contra a poluição e as agressões à Vida Humana e à Natureza.” Em complementação, recomenda que sejam refletidas nas demonstrações contábeis e relatórios da administração das empresas as diretrizes ecológicas adotadas, as quais devem “...se ajustar a um novo mundo, no qual metas ambientais, além das econômicas, terão de ser alcançadas rigorosamente.”

A ONU - Organização das Nações Unidas tem estudado os aspectos contábeis aplicados e aplicáveis aos eventos e transações de natureza ambiental.. Em julho de 1997, emitiu um 
Pronunciamento (UN-ISAR, 1997, p. i), no qual afirma que o objetivo das demonstrações contábeis é fornecer informações sobre a posição financeira de uma empresa, visando às necessidades dos diversos usuários, que as utilizam para tomar decisões, e dos gestores, no que tange à administração dos recursos que lhes foi confiado.

O objetivo específico do trabalho foi o de sintetizar as práticas contábeis utilizadas por organizações governamentais e não-governamentais no que diz respeito aos tratamentos dos eventos e transações de natureza ambiental, com vistas a orientar empresas, comitês de normatização contábil sobre as melhores alternativas para a contabilização dos mesmos.

Tem-se observado nos últimos anos, especificamente na última década, não só no Brasil, mas principalmente nos países europeus e nos EUA, algumas iniciativas no sentido de tornar públicos dados de natureza social, por meio do Relatório da Diretoria que compõe o conjunto das Demonstrações Contábeis. Estes dados são relativos à gestão dos recursos humanos, aos investimentos realizados e programas de controle, preservação e proteção na área ambiental, porém sem padronização e freqüência. Embora sem a preocupação com uniformidade, são conhecidos exemplos de publicação de balanços ambientais qualitativos e quantitativos - física e monetariamente (BSO Origin - Holanda e MODO - Suíça), ${ }^{4}$ os quais demonstram detalhadamente o empenho destas Organizações no tratamento da questão ambiental. Nos Estados Unidos, conforme pesquisa realizada pela KPMG com 885 empresas, $71 \%$ destas informaram os gastos com o meio ambiente no Balanço Patrimonial (Passivos Ambientais e investimentos em equipamentos de proteção e preservação ambiental), enquanto que $24 \%$ elaboraram o balanço ambiental. (FOLHA DE SÃO PAULO, 1997, caderno Dinheiro, p. 2)

Ademais, há publicação de relatórios de políticas, metas e objetivos para a área do meio ambiente, elaborados, essencialmente, por empresas que obtiveram o certificado de qualidade, conforme diretrizes da ISO 14000 e suas subséries, como, por exemplo, a Bahia Sul, a Hering Têxtil, DSM Elastômeros Brasil, a Petroflex e a Pilkington, no Brasil, e a

${ }^{4}$ Relatório Anual - Conjunto de Demonstrações Contábeis de 1992 a 1996. 
Bristish Gas, o National Westminster Bank e a Volkswagen, no exterior (HOJDA, 1997, $p$. 104-113). Estas são empresas impulsionadas pela gravidade da problemática ambiental; pelas penalidades e restrições, facilmente impostas às companhias consideradas potencialmente poluidoras; e pelas exigências para obtenção do certificado de qualidade ambiental.

No Brasil, até abril de 1998, 37 empresas já possuíam o certificado de qualidade ambiental, conforme diretrizes da ISO $14000^{5}$, como demonstra o quadro abaixo:

\begin{tabular}{|c|c|c|}
\hline NOME DA EMPRESA & LOCALIDADE & SETOR \\
\hline RIOCELL S/A & Guaíba - RS & Papel e Celulose \\
\hline PETROFLEX INDÚSTRIA E COMÉRCIO S/A & Triunfo - RS & Petroquímico \\
\hline DSM ELASTÔMEROS BRASIL LTDA & Triunfo - RS & Petroquímico \\
\hline OPP PETROQUÍMICA S/A & Triunfo-RS & Petroquímico \\
\hline OPP POLIETILENOS S/A & Triunfo - RS & Petroquímico \\
\hline COPESUL & Triunfo - RS & Petroquímico \\
\hline HERING TÊXTIL S/A & Blumenau-SC & Têxtil \\
\hline INDÚSTRIA DE AZULEJOS ELIANE & Cocal do Sul - SC & Construção Civil \\
\hline PETROFLEX S/A & Caxias - RJ & Petroquímico \\
\hline BRASIL AMARRAS & Niterói - RJ & Naval \\
\hline OPP POLIETILENOS S/A & Capuava-SP & Petroquímico \\
\hline SPAL IND. BRAS.DE BEBIDAS S/A & Jundiaí - SP & Bebidas \\
\hline NEC DO BRASIL & São Paulo - SP & Eletroeletrônico \\
\hline ROHM AND HAAR QUÍMICA LTDA & $\begin{array}{l}\text { São José dos Campos } \\
\text { - SP }\end{array}$ & Químico \\
\hline TETRA PARK LTDA & Monte Mor - SP & Embalagens \\
\hline KLÜBER LUBRIFICATION LUBRIF.ESPEC.LTDA & Barueri - SP & Lubrificantes \\
\hline SCANIA LATIN AMERICA LTDA & $\begin{array}{ll}\text { São } & \text { Bernardo do } \\
\text { Campo - SP }\end{array}$ & Automobilístico \\
\hline BLINDEX VIDROS DE SEGURANÇA LTDA & Caçapava-SP & Vidros p/Veículos \\
\hline VOLKSWAGEM DO BRASIL & São Carlos - SP & Automobilístico \\
\hline ALPARGATAS SANTISTA TÊXTIL S/A & Americana - SP & Têxtil \\
\hline
\end{tabular}

\footnotetext{
${ }^{5}$ Fonte: INMETRO - Instituto Nacional de Metrologia, Normalização e Qualidade Industrial.
} 


\begin{tabular}{|c|c|c|}
\hline NOME DA EMPRESA & LOCALIDADE & SETOR \\
\hline DURATEX S/A & São Paulo - SP & Florestal \\
\hline PHILIPS DO BRASIL LTDA & Capuava-SP & Eletroeletrônico \\
\hline $\begin{array}{l}\text { ECOSISTEMA GERENCIAMENTO DE RÉSIDUOS SÓLIDOS } \\
\text { INDUSTRIAIS }\end{array}$ & $\begin{array}{l}\text { São José dos Campos } \\
\text { - SP }\end{array}$ & $\begin{array}{l}\text { Tratamento de } \\
\text { Resíduos }\end{array}$ \\
\hline FURUKAWA & Lorena - SP & Eletroeletrônico \\
\hline CEBRACE & $\begin{array}{l}\text { São José dos Campos } \\
\text { - SP }\end{array}$ & Vidros Planos \\
\hline CENTRO DE EXCELÊNCIA P/SISTEMA DE GESTÃO & Barueri-SP & Consultoria em SGA \\
\hline USIMINAS & Ipatinga - MG & Siderúrgico \\
\hline SUTEC - SUPERINTENDÊNCIA DE TECNOLOGIA DA CVRD & Santa Luzia - MG & $\begin{array}{ll}\text { Tecnologia para } \\
\text { Mineração }\end{array}$ \\
\hline CBMM - CIA BRAS. DE MINERAÇÃO E METALURGIA & Araxá-MG & Mineração \\
\hline CELULOSE NIPO-BRASILEIRA S/A & Belo Oriente - MG & Papel e Celulose \\
\hline FIAT AUTOMÓVEIS S/A & Betim - MG & Automobilístico \\
\hline CIA CERVEJARIA BRAHMA & Mateus Leme - MG & Bebidas \\
\hline OPP POLIETILENOS S/A & Camaçari-BA & Petroquímico \\
\hline CETREL S/A & Camaçari - BA & $\begin{array}{l}\text { Tratamento de } \\
\text { Resíduos Industriais }\end{array}$ \\
\hline BAHIA SUL CELULOSE S/A & Mucuri-BA & Papel e Celulose \\
\hline PETROFLEX INDÚSTRIA E COMÉRCIO S/A & $\begin{array}{lll}\text { Cabo } \quad \text { de } & \text { Sto } \\
\text { Agostinho }- \text { PE } & \end{array}$ & Petroquímico \\
\hline PETRÓLEO BRASILEIRO S/A - PETROBRAS E\&P & Amazonas - AM & Produção de Petróleo \\
\hline
\end{tabular}

Na grande imprensa aparecem, com bastante freqüência, notícias sobre empresas que estão adotando o processo de reciclagem como forma de reduzir custos e também para diminuir o impacto negativo de suas atividades sobre o meio ambiente. As empresas de papel e celulose, pertencentes a um dos setores mais críticos em termos de poluição, têm adotado metodologias bastante avançadas nos seus processos produtivos de forma a eliminar os resíduos nocivos, próprios da atividade que exercem.

Nos relatórios da administração que acompanham as demonstrações contábeis também podem ser encontradas declarações, de algumas empresas, quanto à sua postura ambiental, 
ainda que não de forma sistematizada.

\subsection{Sintetizando o Balanço Social}

Mesmo levando em conta as iniciativas que têm sido tomadas por algumas empresas, é preciso avançar em direção a um comportamento homogêneo, qualquer que seja sua localização ou porte, tendo em vista propiciar as condições necessárias que permitam ao usuário comparar e analisar dados compatíveis entre si, avaliar a estrutura atual do negócio, além de fazer inferências sobre as tendências futuras. Como conseqüência, e como fruto da responsabilidade social coletiva das empresas, será possível conseguir um planeta ambientalmente saudável no presente e futuro.

GONÇALVES (apud ABAMEC NACIONAL, 1997, p. 13) entende que a busca de qualidade de vida pelo homem moderno estimulou as empresas a se interessarem por “instrumentos de aferição" do seu desempenho nesta área. O Balanço Social surgiu para satisfazer esta nova necessidade.

Ainda segundo o mesmo autor:

"Dois fatores desempenharam papel capital no desenvolvimento dessa linha de inquietações; de um lado, uma pressão crescente sobre a empresa, com vistas a uma preocupação constante com os aspectos sociais envolvidos em suas decisões; de outro lado, uma considerável insegurança quanto ao papel futuro da empresa na sociedade.

A empresa tem procurado responder a esses desafios, desenvolvendo esforços no sentido de tornar mais sociais suas tomadas de decisão. Nesse sentido, já se nota um crescente reconhecimento da necessidade de ampliar as responsabilidades sociais da empresa e de redefinir seu papel e sua missão na sociedade. Para tanto, busca-se um esclarecimento maior a respeito do conceito daquilo que se denomina responsabilidade social, além de se procurar desenvolver cuidadosa análise sobre a integração das preocupações sociais aos 
objetivos da empresa. Dir-se-ia que, no fundo, gera-se uma nova ética empresarial, não apenas dirigida ao indivíduo colocado em seu seio, mas à empresa enquanto instituição.”

MARTINS (GAZETA MERCANTIL, 1997, p. A-3) afirma que o balanço social, na sua forma ampla “...É necessário para uma compreensão melhor da empresa por parte de seus investidores e credores, do governo executivo, dos legisladores, dos julgadores, dos empregados atuais e futuros, sindicatos, "ONGs", instituições acadêmicas e de pesquisa, órgãos reguladores, partidos políticos, autoridades municipais, ou seja, da sociedade como um todo."

Vale ressaltar uma vez mais que o movimento iniciado pelo sociólogo Herbert de Souza - o Betinho, em meados de 1996, fez ressurgir a idéia do Balanço Social, provocando uma ampla discussão de sua importância e chegando a motivar a elaboração de projeto de lei nacional para a instituição obrigatória do mesmo pelas empresas, além de discussões dentro da Comissão de Valores Mobiliários - CVM sobre a questão. Infelizmente, o que se percebe hoje é que a importância do assunto voltou a esmorecer. No entanto, estas iniciativas constituem por si só instrumentos de pressão sobre as empresas por parte da sociedade, podendo gerar novas adesões às iniciativas já tomadas por algumas empresas, quanto à publicação da Demonstração do Valor Adicionado, informações relativas à composição do quadro de empregados e benefícios oferecidos, além de dados sobre investimentos na área ambiental, ainda que de forma esparsa e não sistematizada.

Como muito bem observa MARTINS (GAZETA MERCANTIL, 1997, p. A-3), a questão de identificar qual o tipo, a quantidade de informações, o momento em que podem ser úteis, e até a quem pode interessar de nada adianta se, mesmo o poder público tornando obrigatória a publicação de um rol imenso de dados, estes não tiverem utilidade para a sociedade de forma geral. Segundo suas palavras:

“...não acreditamos na utilidade de tentar passar do nada para um volume de informações tão exagerado e detalhado como o contido no projeto de lei em tramitação no Congresso, 
sem antes testar conteúdo e forma que melhor atendam a nossos interesses no Brasil. Precisamos dar passos firmes, mas não saltos mortais no sentido de ter essas informações, num fluxo que evolua proporcionalmente à capacidade de assimilação por parte dos próprios interessados."

Neste sentido, é bastante prudente o posicionamento da CVM, que primeiro pesquisa a opinião pública, manifesta sua posição de acolher sugestões, para só então emitir um pronunciamento sobre o comportamento a ser seguido pelas empresas sob sua jurisdição: as companhias abertas.

A conscientização do empresariado quanto ao avançado estado de degradação do patrimônio natural que está colocando em risco a vida da humanidade e, por conseguinte, das empresas, fez com que se tornasse compulsória a implantação de sistemas de gerenciamento ambiental pelas empresas. A continuidade (a vida) da empresa é ameaçada pelo esgotamento dos recursos naturais não-renováveis; pela saturação do poder dos recursos naturais para absorção dos resíduos poluentes; pelo crescente rigor adotado pelos governos no controle dos níveis de poluição, utilizando-se, inclusive, de agressivas penalidades que chegam a interferir na continuidade da empresa, ou mesmo proibindo-as definitivamente de funcionar; pela pressão do mercado para expurgar concorrentes, principalmente aqueles com baixo nível de qualidade ambiental dos produtos e processos.

Sistemas de proteção ao meio ambiente devem ser implantados, mantidos e analisados sob a ótica operacional e econômica, com vistas a uma completa avaliação dos resultados obtidos, identificação de necessidade de novos investimentos ou de eliminação dos desnecessários.

Desta avaliação econômico-financeira e física ter-se-á subsídios para a elaboração do Balanço Social, visando à prestação de contas ao público, seja interno ou externo, quanto à postura da Organização, como também para avaliar os custos inerentes ao controle 
ambiental, sua adequabilidade, sua contribuição no resultado global e o desempenho do gestor ambiental.

Abordando a questão da responsabilidade social, GLAUTIER e UNDERDOWN (1995, $p$. 417) entendem que o conceito de contabilização das responsabilidades sociais tem origem na definição dos usuários de tais informações, nos seus objetivos em recebê-las e, primordialmente, na definição da responsabilidade social da corporação que se fundamenta nas regras sociais dos negócios impostas pela sociedade.

Ainda segundo esses autores, o conceito de responsabilidade social da corporação estendese muito além da incorporação dos requisitos determinados por legislação. A definição deste conceito necessita de um emergente debate a partir das teorias sociais e políticas, principalmente no que tange:

- à natureza da responsabilidade social da corporação;

- aos objetivos para os quais as informações contábeis podem ser direcionadas;

- ao escopo da responsabilidade social da corporação;

- à maneira como a informação é divulgada .

Uma questão importante quanto à definição de quais sejam as preferências e prioridades dos diversos usuários no que diz respeito à responsabilidade social da companhia, sem um prévio e preciso conhecimento de tais preferências e prioridades, faz com que muitas das discussões do que seja desejável socialmente ocorram com base em julgamentos subjetivos, ou pior, decorram de puro trabalho de adivinhação.

Outro aspecto a ser considerado é concernente ao fato de que os custos ou benefícios sociais existem dependendo da ótica de percepção social, no que tange à definição do que é bom ou ruim. Além disso, o conceito de responsabilidade social não é algo estático: muda conforme os objetivos, usuários e tempo. 
Tratando ainda da natureza da responsabilidade social, GLAUTIER e UNDERDOWN (1995, p. 417) ressaltam que não há um conceito generalizado sobre responsabilidade social; porém, há quase unanimidade no sentido de que todos devem ser socialmente responsáveis, em função da doutrina universal de que todos devem pesar o impacto de suas ações sobre os outros, ou seja, o direito de cada um vai até o limite em que se inicia o direito do outro.

$\mathrm{Na}$ ausência de uma clara definição do que seja a responsabilidade social da empresa, as companhias devem decidir individualmente a natureza de sua responsabilidade social como um conceito gerencial e obrigatório. A única orientação disponível é a de que há legislações, de um lado, e opinião pública e pressões, do outro. 


\section{III - ITENS DE NATUREZA AMBIENTAL DO PATRIMÔNIO DAS COMPANHIAS}

Este capítulo objetiva identificar os recursos econômicos-financeiros das empresas que refletem sua interação com o meio ambiente, bem como descrever o tratamento contábil recomendado por algumas Entidades de estudos contábeis, como a ONU, o FASB (EUA), o CICA (Canadá), ICAEW (Inglaterra e País de Gales) e EAAF (Europa).

\section{A - Eventos e Transações com Impacto no Patrimônio das Empresas}

Como já mencionado, os investimentos na área ambiental representam grandezas relevantes e, assim sendo, causam significativo impacto sobre a situação econômicofinanceira das empresas. Na tentativa de deixar esta informação mais evidente, seguem-se alguns fatos que, com certeza, alteraram significativamente a situação patrimonial da companhias envolvidas.

Segundo relatos de EPELBAUM (1997, p. 242):

“ - a Spal, principal franqueada da Coca-Cola no Brasil, em sua unidade situada em Jundiaí/SP, introduziu controles sobre as emissões atmosféricas de sua frota de 1000 veículos de transporte de produtos; substituiu, na aquisição de novas máquinas "post-mix", os gases CFC's por outros menos agressivos à camada de ozônio; economizou R\$ 600.000,00 com a diminuição do consumo de água, energia e o gerenciamento de resíduos; patrocina programas de reciclagem de latas de alumínio; (De acordo com informações internas da empresa, isto se deu entre 1995 e 1996. E em 1997, a empresa obteve o certificado ISO 14000).

- a Bahia Sul, produtora de celulose e papel, situada no sul da Bahia, reduziu o consumo de água específico de 64,9 m3/t de produto (1994) para 53,5 m3/t (meados de 1996); 
introduziu programa de coleta seletiva de resíduos sólidos, arrecadando R \$ 450.000,00 somente com a sua venda;

- a DSM, produtora de borracha EPDM (borracha sintética), situada no Pólo de Triunfo/RS, introduziu programa de coleta seletiva de resíduos sólidos, reduziu a geração de efluentes líquidos e de resíduos industriais, contabilizando economias de R \$60.000,00; (De acordo com informações obtidas na empresa, o fato se deu no segundo semestre de 1996, e o total da economia de custos gerado pelo conjunto dos programas de controle ambiental implantados no período foi de $R \$ 100.000,00)$.

- a Petroflex, produtora de borracha SBR, também situada no Pólo de Triunfo/RS, reduziu em 20\% a geração de efluentes líquidos por tonelada de produto (1996).”

JÖHR (1994, p. 28 - 31) menciona o caso do proprietário de uma empresa canadense que foi condenado a seis meses de prisão, em 1990, como penalidade porque sua empresa descarregava efluentes tóxicos em um rio. Nos EUA, também em 1990, “...um júri federal condenou o presidente de uma empresa ótica, a Borjohn Optical Technology Inc., pela emissão de substâncias tóxicas no esgoto local. A empresa foi multada em US\$ 50 mil e seu presidente, John Borowski, foi sentenciado a vinte e seis meses de prisão, além de ter sido multado em US\$ 400 mil. Pior: a Borjohn Optical entrou para o índex nacional das "companhias sujas" e tornou-se "inelegível" para contratos, garantias e empréstimos relacionados ao governo federal."

O mesmo autor relata também o caso Exxon-Valdez:

“Em 24 de março de 1989, o petroleiro Valdez, da Exxon, encalhou próximo a Valdez, no Alasca. Nos quinze dias que se seguiram, mais de 10 milhões de galões de óleo foram derramados no mar, alastrando-se por $7600 \mathrm{~km}^{2}$. O óleo cru manchou e poluiu a costa, matando peixes, aves, mamíferos e vegetação que tiveram o azar de estar em sua área. A 
devastação econômica daí resultante foi enorme: naufragou a exploração comercial de salmão, arenque, outros recursos da pesca, isso sem mencionar a indústria turística.

Embora o derramamento de óleo ocorrido no episódio Exxon Valdez tenha correspondido a apenas $15 \%$ do total do derramado na costa francesa, em 1978, pelo petroleiro AmocoCadiz (68 milhões de galões), o preço pago pela Exxon foi dezessete vezes mais alto. Só nos trabalhos de recuperação ambiental, a Exxon tirou do bolso mais de US\$ 2 bilhões. Alguém pode se perguntar por quê, e a resposta é simples: no lapso de onze anos, a consciência ambiental, traduzida em novas leis mais severas e num novo patamar de exigência do consumidor, cobra cada vez mais caro os erros cometidos. Além disso, os consumidores chegaram a boicotar os produtos Exxon, ocasionando uma perda de receita para a empresa." (grifos do autor)

O mesmo JÖHR expôs o caso Cubatão:

“Em 1984, uma tragédia sacudiu Cubatão. Duas fortes explosões e o incêndio que se seguiu, provocados por um vazamento de gasolina nos dutos da Petrobrás, incineraram mais de mil casas no bairro de Vila Socó e mataram mais de cento e cinqüenta pessoas. Os sobreviventes foram reassentados numa nova vila, porém a Petrobrás não foi multada. E como poderia? Tratava-se de um monopólio estatal e qualquer multa seria paga pelos impostos dos contribuintes. Nesse contexto, as multas não fazem sentido. ...

No ano seguinte, 1985, outro desastre de enormes proporções ocorreu: o vazamento da amônia de um duto da Ultrafértil, na Vila Parisi...

O preço dessas tragédias não foi apenas um arranhão na imagem do País, aqui e no exterior. Elas custaram caro também em moeda corrente: somas impossíveis de se calcular em detalhes, mas astronômicas. Fábricas paradas, danos reparados, indenizações pagas às famílias das vítimas - tudo somado, mais as despesas em programas de relações públicas para resgatar a imagem das empresas poluentes e, sobretudo, os investimentos necessários 
para se diminuir o padrão técnico de riscos, os desastres de Cubatão, até 1992, custaram algo em torno de US\$ 650 milhões. Destes, estima-se que cerca de US\$ 500 milhões foram investidos por vinte e três empresas no pólo petroquímico só em equipamentos antipoluição."

A observação destes casos, comumente divulgados pela grande imprensa, reflete a relevância que têm os gastos ambientais. Eles podem interditar empresas, retardar significativamente a evolução destas, à medida que recursos tenham que ser desviados para cumprir penalidades. Os gastos na aquisição e/ou desenvolvimento de tecnologias, máquinas e equipamentos antipoluentes causam, via de regra, um impacto significativo sobre o fluxo de caixa presente das empresas, embora de fundamental importância para assegurar os fluxos de caixa futuros e a rentabilidade do negócio. Os desembolsos adicionais, referentes à área ambiental, requeridos pelos processos produtivos, bem administrados, podem resultar em economias de custos, essencialmente no que tange à redução de perdas de matéria-prima, otimização da produtividade e melhoria das condições de competitividade no mercado. Além do mais, de forma geral, os investimentos para a proteção ambiental podem reduzir, drasticamente, o volume de gastos com recuperação de áreas degradadas, multas (as quais se tornaram bastante relevantes) e obrigações de ressarcimento a terceiros por danos ambientais provocados.

$\mathrm{O}$ aspecto econômico e financeiro de todos estes eventos e fatos são, via de regra, de grande monta, como demonstram os exemplos, devendo, portanto, ser identificados e mensurados para a elaboração de informações no concernente à situação patrimonial das companhias, bem como de seus impactos sobre o meio ambiente e dos impactos deste sobre o patrimônio da organização. 


\section{B - Itens Ambientais do Balanço Patrimonial}

Assim, sabendo-se que todos os gastos voltados para a área ambiental, em algum momento, vão tornar-se custos e, portanto, serão transferidos para o resultado do exercício, conforme o tempo e o potencial esperados de geração de benefícios econômicos, importante se faz definir alguns termos para a contabilidade ambiental.

\section{1 - ATIVO AMBIENTAL}

O ativo na forma genérica recebe, entre outras, ${ }^{6}$ a seguinte definição:

Ativos são recursos econômicos controlados por uma entidade, como resultado de transações ou eventos passados e dos quais se espera obter benefícios econômicos futuros.

À definição genérica do termo - ativo - vale acrescentar que estes devem ter por finalidade o controle, preservação e recuperação do meio ambiente. Em decorrência, ter-se-á como definição de ativo ambiental:

Ativos ambientais são recursos econômicos controlados por uma entidade, como resultado de transações ou eventos passados, e dos quais se espera obter benefícios econômicos futuros, e que tenham por finalidade o controle, preservação $e$ recuperação do meio ambiente.

No Canadá, um grupo de estudos do Instituto de Contadores (CICA, 1992, p. 24) definiu o Ativo Permanente Ambiental como aqueles itens:

\footnotetext{
${ }^{6}$ Vide outras definições em RIBEIRO (1992, p. 83-89).
} 
- mantidos para adequar ambientalmente a qualidade da produção, da prestação de serviços ou o fornecimento de mercadorias;

- adquiridos, construídos ou desenvolvidos com a intenção de serem usados no controle ambiental necessário à continuidade básica da companhia; e

- sobre os quais não exista a intenção de venda no curso normal dos negócios.

O EITF 90-8, do FASB (1990), estabelece que os gastos de tratamento de contaminação ambiental poderão ser registrados como ativo permanente se:

- forem recuperáveis;

- proporcionarem aumento de vida útil, capacidade ou melhoria de segurança e eficiência;

- se forem incorridos para o preparo do ativo para a venda.

Segundo a ONU (UN-ISAR, 1997, p. iv):

Os gastos ambientais poderão ser classificados como ativo imobilizado se efetuados com o objetivo de prevenir ou reduzir danos ambientais futuros, ou conservar recursos, e, ainda, se houver a pretensão de usá-los continuamente nas atividades da empresa, desde que um dos critérios seguintes seja satisfeito:

a) os gastos devem estar relacionados com a antecipação de benefícios ambientais e extensão de vida útil dos ativos, aumento de capacidade, melhoria de segurança e eficiência dos ativos da companhia; ou

b) os gastos devem propiciar a redução ou prevenção de contaminações ambientais que possam ocorrer como resultado de operações futuras.

Os gastos ambientais poderão ser capitalizados se forem realizados para preparar um ativo ou atividade para operação, desde que o dano ao meio ambiente não possa ser evitado e haja a obrigação de ser retificado em algum momento do futuro. 
Quando um gasto ambiental, que tenha as condições para ser reconhecido como ativo permanente, estiver relacionado a outro ativo, deverá ser incluído como parte daquele ativo, e não registrado separadamente.

Todos os ativos imobilizados, incluindo os gastos ambientais que serão incorporados ao ativo permanente, deverão ser rigorosamente examinados para certificação de que refletem o benefício econômico deles esperado.

Explanando sobre o conceito de ativo, a ONU argumenta que:

“A definição de um ativo indica que quando o gasto incorrido por uma empresa resultar em benefícios econômicos futuros este deve ser capitalizado e amortizado no resultado dos períodos em que tais benefícios são esperados. A capitalização também é considerada apropriada quando os gastos ambientais são incorridos por razões ambientais ou de segurança, mesmo que não aumentem os benefícios econômicos futuros esperados, mas que sejam necessários para assegurar que a empresa obtenha ou continue a obter os referidos benefícios de outros ativos." (tradução livre)

\subsection{Gastos Ambientais com Características de Ativos Ambientais}

\subsubsection{Recursos Utilizados no Processo de Recuperação de Danos Ambientais}

Alguns processos de recuperação ou restauração do meio ambiente, decorrentes de danos provocados pelo processo operacional da empresa, exigem a aquisição de recursos, seja de consumo imediato (custos), seja de vida útil mais extensa (ativos).

Os ativos de vida útil mais extensa e de valor relevante poderão se caracterizar como ativo permanente, no caso de haver a intenção ou necessidade de permanecer com os mesmos na companhia por um longo período de tempo. Isto, se houver a expectativa, no mínimo, de garantir a realização dos benefícios econômicos em períodos futuros. 
No caso, os gastos com a aquisição, construção ou desenvolvimento destes bens enquadram-se nas premissas acima descritas, pois são necessários para:

- adequar ambientalmente a qualidade da produção, da prestação de serviços ou do fornecimento de mercadorias;

- o controle ambiental; e

- a continuidade básica da companhia, desde que não haja a intenção de venda no curso normal dos negócios.

\subsubsection{Posição da ONU (UN-ISAR, 1997, p. iv $)$}

A ONU refere-se aos gastos necessários a futuras restaurações, relacionados a danos incorridos em períodos passados:

“Os gastos ambientais necessários à restauração de áreas contaminadas, decorrentes de danos ocorridos na preparação de um ativo, ou atividade operacional, que tenham sido apurados no momento em que os danos foram provocados, podem ser capitalizados." (tradução livre)

O Pronunciamento da ONU explica que em muitas situações o dano ambiental ocorre antes de a empresa iniciar uma determinada atividade e também ao longo do desenvolvimento destas, como, por exemplo, no caso de exploração de minérios em que as operações não podem começar sem que haja os trabalhos de escavações (estas representam um dano ambiental). As empresas são freqüentemente obrigadas a providenciar a restauração local, depois de encerradas as atividades. Tais gastos de restauração podem ser provisionados pelo total, quando o dano ambiental estiver sendo realizado. O total poderá ser capitalizado e amortizado no resultado dos períodos durante a vida útil da atividade. 
A ONU ressalta que gastos ambientais reconhecidos como ativos, mas relacionados a outros ativos, podem ser integrados como parte do custo destes, sem uma segregação para ativo ambiental.

Esta posição decorre do fato de que em muitas situações os gastos ambientais passíveis de capitalização estão relacionados a outros ativos, sem que haja um benefício econômico futuro específico para aqueles de natureza ambiental. Os benefícios econômicos futuros permanecem no ativo que é utilizado nas atividades operacionais da empresa, como, por exemplo, a remoção de asbestos de um prédio, que não resulta em futuros benefícios econômicos ou ambientais. O prédio é que proporcionará o benefício econômico futuro. Portanto, é inapropriado reconhecer os gastos com tal remoção como um ativo separado. Por outro lado, uma parte do maquinário que remove poluição da água ou atmosfera poderá gerar um benefício econômico futuro específico, cabendo, portanto, neste caso, a contabilização de um ativo ambiental.

\subsubsection{Posição dos EUA (EITF 90-8)}

O EITF 90-8 - FASB, como já mencionado, estabelece que:

... em geral, os gastos com tratamento de contaminação ambiental deverão ser contabilizados como despesas, podendo ser registrados como ativo permanente se forem recuperáveis e pelo menos um dos seguintes critérios for atendido, tomando-se como base comparativa a condição existente no momento da aquisição ou término da construção ou desenvolvimento:

Se os custos:

a) proporcionarem um prolongamento da vida útil, aumento da capacidade ou melhoria da segurança ou eficiência do bem; 
b) contribuírem para a redução ou prevenção de contaminação ambiental, decorrente das operações da empresa;

c) forem incorridos no preparo para a venda da propriedade mantida para tal. (tradução livre)

\subsubsection{Posição do Canadá(CICA, 1992, p. 23-40)}

Um estudo realizado no Canadá mostra que os gastos relacionados com a recuperação de danos ambientais serão agregados ao valor do ativo somente se, no momento da aquisição, houver conhecimento da sua necessidade ou exigência legal. Caso contrário, ou seja, quando a necessidade de recuperação ou restauração de danos ambientais ocorridos anteriormente à aquisição é identificada em momentos posteriores, os gastos constituir-seão em uma perda do período em que forem realizados.

Esta posição parte da premissa de que, no momento da aquisição, ou durante o processo de construção ou desenvolvimento de ativos, estão disponíveis todas as informações necessárias à identificação e avaliação dos benefícios econômicos futuros, e qualquer alteração desta projeção resulta em perda para a companhia, em face do que era esperado.

Contudo, alguns membros do grupo que elaborou este estudo entendem que se os gastos contribuírem para a realização da expectativa de benefícios futuros, mesmo sem alterá-la, mas garantindo-a, estes devem ser agregados ao valor dos ativos. Enquadram-se nesta situação os gastos de recuperação de áreas poluídas, os gastos de adequação de construção ou bens desenvolvidos pela empresa, necessários à efetiva operação das atividades da companhia.

Há, ainda, uma divergência entre os membros do grupo de estudo quanto ao tratamento dos gastos incorridos em decorrência da instituição de uma nova lei ou regulamentação. Uma parte deles acredita que tais gastos beneficiariam o meio ambiente, mas não geraria 
aumento da expectativa de benefícios futuros. Outros associam o cumprimento da exigência legal à continuidade operacional dos ativos e, assim sendo, mesmo sem aumentar os benefícios futuros, estes gastos asseguram a expectativa inicial.

\subsubsection{Gastos Posteriores ao Momento do Ingresso como Ativo}

Conforme as premissas básicas contábeis, quaisquer alterações a serem feitas no valor dos ativos devem estar embasadas em um aumento de expectativa de benefícios futuros esperada daquele ativo, ou no fato de que os gastos se constituem em condição elementar para que o fluxo de benefícios planejados se concretize. Obviamente, serão precedidos de um estudo para a avaliação do custo-benefício dos investimentos em um ativo já existente, comparativamente à aplicação de recursos em um novo ativo.

Alguns gastos de natureza ambiental podem resultar em benefícios imediatos para a comunidade em geral, com a melhoria da qualidade do meio ambiente ou conservação de recursos naturais. Para a empresa, porém, os reflexos virão somente a longo prazo, à medida que ela se conceitue como uma organização ambientalmente responsável, e se distinga ou se compare com suas concorrentes, otimizando, com isso, a demanda pelos seus produtos e serviços, como, por exemplo, os investimentos em equipamentos de tratamento de resíduos poluentes, ou em alterações nas estruturas físicas da empresa para reduzir ou eliminar resíduos tóxicos.

O aumento na expectativa de benefícios econômicos futuros dos ativos reflete-se no aumento do resultado físico ou da capacidade de serviços, na melhoria da qualidade dos resultados, na extensão da vida útil dos ativos e na redução de custos.

Esta elevação do potencial de serviços dos ativos pode ser decorrente do fato de os ativos se eximirem dos desgastes provocados pelos resíduos poluentes que os próprios produziam, ou de terem energias poupadas da produção destes. A qualidade ambiental do local onde os ativos são instalados é, igualmente, fator fundamental para determinar seu 
potencial de serviços, como, por exemplo, o caso dos equipamentos utilizados para geração de energia da Eletropaulo instalados em rios poluídos (RIBEIRO, 1992, p. 93); o tratamento destes rios com certeza devolverá a estes ativos, em alguns casos, até $50 \%$ de potencial de serviços, atualmente deteriorados pela poluição.

Os ativos adquiridos em condições inadequadas ambientalmente teriam, em princípio, embutido em seu valor de negociação a dedução dos gastos necessários às correções, restaurações ou recuperações.

Porém, deduzidos ou não do valor da aquisição, tais gastos serão incorporados ao valor do ativo se forem necessários para tê-lo em condições de uso ou funcionamento. A conseqüência estará refletida no fluxo de benefícios futuros esperados, o qual poderá ser maior ou menor, dependendo das condições acordadas na transação de compra e venda.

As empresas do setor de Siderurgia são consideradas potencialmente poluidoras. $\mathrm{Na}$ época em que houve um grande número de privatizações das estatais brasileiras (1992), constatou-se que, embora não houvesse registro contábil, existia um volume significativo de obrigações de natureza ambiental a serem cumpridas pelos novos proprietários, como pagamento de multas, restauração e recuperação de áreas poluídas, bem como obrigatoriedade de adequação dos recursos operacionais, no sentido de reduzir ou eliminar os níveis de poluição emitidos. Estes valores foram reduzidos do preço de venda proposto. Nestes casos, o valor dos ativos deveriam ter sido registrados pelo valor de aquisição, somados, posteriormente, aos gastos com a adequação operacional das companhias. (RIBEIRO, 1992, p. 121-122)

\subsubsection{Gastos para Conservação de Recursos e Prevenção ou Redução de Danos}

Deverão ser incorporados ao valor do ativo os gastos relevantes destinados à conservação de recursos, prevenção e/ou redução de eventuais danos ambientais futuros, desde que estes gastos, incorridos durante a construção ou desenvolvimento do ativo ou após a sua 
aquisição, aumentem a expectativa de benefícios futuros ou sejam necessários à manutenção da expectativa anteriormente delineada.

\subsection{Ativos Mantidos para Venda}

A declaração de intenção de venda de bens integrantes do ativo permanente, em conjunto com o abandono de sua utilização, enseja a transferência destes para o ativo circulante.

De acordo com a posição do $C I C A(1992$, p. 23 - 40), a partir do momento em que passa a existir a intenção de venda dos bens adquiridos com a finalidade de controle, preservação e recuperação do meio ambiente, enquanto mantidos na companhia estes bens perdem a condição de ativo permanente ambiental, devendo ser transferidos para o grupo de contas do Ativo Circulante, sem qualquer vinculação com a questão ambiental.

O valor a ser transferido para o ativo circulante é o custo líquido de aquisição ou construção dos ativos, entendendo-se como tal o somatório de todos os gastos realizados para atingir condições de uso, deduzido das depreciações e amortizações. O EITF 90-8, que trata da capitalização de custos para tratamento de contaminação ambiental, permite, ainda, a incorporação dos gastos incorridos no preparo de bens para deixá-los em condições de venda sob a premissa de que serão recuperáveis.

A recuperação do custo do ativo mantido para a venda é determinada pelo mercado onde a empresa atua, considerando as oscilações de preços e os efeitos da inflação. 


\section{2 - PASSIVO AMBIENTAL}

Os passivos são constituídos a partir da expectativa de sacrifícios de benefícios econômicos futuros. ${ }^{7}$

Obedecendo à premissa acima descrita, vale acrescentar que:

os passivos ambientais devem ser constituídos pela expectativa de sacrifício de benefícios futuros impostas por legislações e regulamentações ambientais, como taxas, contribuições, multas e penalidades por infrações legais e, ainda, em decorrência de ressarcimento a terceiros por danos provocados, estimativa de gastos para recuperação e restaurações de áreas degradadas, seja por iniciativa própria, seja exigido por lei ou terceiros. Enfim, todos os compromissos que impliquem o provável consumo de recursos futuros para fazer face às obrigações decorrentes de questões ambientais.

Em contrapartida, ter-se-á a constituição de despesas e ativos ambientais, conforme o devido regime de competência.

Os passivos, ambientais ou não, devem ser constituídos por todas as obrigações conhecidas e mensuráveis, até o momento do encerramento das demonstrações contábeis. Nisto está implícito o regime de competência, segundo o qual todas as transações e eventos devem ser registrados no momento em que o fato gerador ocorre. Ressalte-se, ainda, que algumas obrigações são conhecidas, mas não mensuráveis, ainda que por meio de estimativas razoáveis. Neste caso, as notas explicativas às demonstrações contábeis devem ser utilizadas para evidenciá-las.

\footnotetext{
${ }^{7}$ Vide outras definições RIBEIRO (1992, p. 97-103)
} 
O reconhecimento de um passivo exige a identificação do montante do sacrifício de recursos que será realizado. Muitas vezes a identificação deste valor extrapola o recebimento de um comunicado externo de cobrança. Algumas vezes, a exigibilidade existe e a empresa possui os parâmetros para determinar ou estimar razoavelmente o valor a ser desembolsado, classificando-o dentro do devido regime de competência. Em outros casos, a empresa precisa utilizar cálculos estimativos para fazer o reconhecimento do passivo.

Assim, a empresa pode adquirir, a prazo, de terceiros, insumos ou equipamentos antipoluentes, necessários à adequada operacionalização de suas atividades, recebendo destes uma nota fiscal-fatura que fundamentará o registro contábil da exigibilidade ambiental. Há casos em que a empresa mantém um corpo de funcionários dedicados, exclusivamente, à operacionalização e manutenção de seus equipamentos antipoluentes; neste caso, possui todos os parâmetros legais para a determinação do valor dos salários e encargos sociais, decorrentes da remuneração deste pessoal. Ou ainda, mediante o controle de horas das tarefas executadas por seus funcionários, poderá segregar o volume de tempo despendido nas atividades relacionadas ao controle ambiental, dado que estas ocorrem nas diversas áreas da empresa, e não somente na área de controle ambiental.

Ao iniciar um processo de restauração ou recuperação de uma área contaminada a empresa poderá ter em mãos o resultado de estudos técnicos de engenharia que lhe aponte todos os recursos que serão necessários à realização dos trabalhos, podendo providenciar um levantamento do custo monetário destes recursos. Naturalmente, todo o valor obtido a partir de estimativas está sujeito a alterações, as quais poderão ser corrigidas quando de sua identificação. Mas o importante é ter um valor, ainda que aproximado, dos gastos que a empresa terá que efetuar. Sendo gastos de natureza ambiental, refletem o empenho no cumprimento de sua responsabilidade sócio-ambiental.

Todos os eventos e transações de natureza econômico-financeira, inclusive as exigibilidades ambientais, devem ser contabilizados no momento em que ocorrem seus 
fatos geradores. Na hipótese de haver dúvidas quanto à real responsabilidade da empresa no cumprimento da exigibilidade, ou quanto ao seu montante, apesar de o fato gerador ter ocorrido realmente, algumas questões precisam ser definidas:

\section{a empresa:}

- está disposta a reparar o prejuízo provocado?

- é obrigada legalmente a tal?

- é a única responsável?

- em qualquer das hipóteses acima, qual o valor?

$\mathrm{Na}$ verdade, se o fato gerador ocorreu, se o meio ambiente foi degradado, socialmente a empresa tem a obrigação de recuperá-lo; contudo, percebe-se que ao longo do desenvolvimento das atividades econômicas esta questão foi ignorada. Por falta de conhecimento, tecnologias e interesses, as empresas se mantiveram, e grande maioria ainda se mantêm, omissas a estas obrigações.

Com o rigor com que as legislações têm sido dotadas, e com o esclarecimento que a sociedade, de uma forma geral, tem quanto aos seus direitos de cidadania, algumas empresas são legalmente forçadas a assumir sua responsabilidade ambiental.

No caso de contaminação do solo e águas em áreas comuns, em mais de uma empresa localizada na mesma região, com características semelhantes do processo operacional e que sempre se mantiveram com o mesmo grau de adequação à qualidade ambiental, a exigibilidade pelo ressarcimento do prejuízo deve ser distribuída entre as partes.

Definida a real responsabilidade da companhia, se não houver, de imediato, uma cobrança formalizada que embase o registro contábil, deve-se constituir uma provisão para reconhecimento da provável exigibilidade, a qual requer a apuração de um valor, ainda que por meio de cálculos estimados, caso em que o resultado do exercício corrente receberá a 
contrapartida. Na hipótese de impossibilidade de se estimar tal valor, as notas explicativas às demonstrações contábeis serão utilizadas para dar ampla divulgação da existência da exigibilidade e da razão pela qual seu valor não pode ser estimado.

Conservadoramente, o valor da estimativa deve abranger todos os possíveis gastos a serem efetuados (convenção do conservadorismo: os ativos devem estar registrados, sempre, pelo menor valor possível, e os passivos, pelo maior valor).

No cálculo de estimativa de gastos devem ser incluídos apenas os valores relativos aos trabalhos de recuperação que sejam de responsabilidade da companhia, caso haja mais de um responsável.

Estimativas são previsões de gastos com base em expectativas de eventos que irão ocorrer. Dado às incertezas que permeiam o futuro, o montante de recursos utilizados para quitar as exigibilidades pode variar em função de causas diversas: erro de cálculo da quantidade necessária de insumos, oscilação de preços, extensão e profundidade da área a ser recuperada, ou, ainda, deterioração do poder aquisitivo da moeda pelas estrutura econômica.

Desta forma, o valor do complemento das estimativas deve ter a contrapartida debitada aos custos ambientais, componentes do resultado do exercício em curso, dado que a variação ocorreu em função de novos eventos e/ou informações.

\subsubsection{Posição da ONU(UN-ISAR, 1997, p. 8-9)}

A ONU menciona obrigações:

- legais: são as provenientes de instrumentos de força legal (legislações, penalidades impostas por lei etc.) 
- construtivas: são aquelas a que a empresa se propõe, espontaneamente, a cumprir e que extrapolam as exigências legais. Na área ambiental, por exemplo, a ação dos órgãos técnicos governamentais se dá, normalmente, via indicadores de teor de poluição. E é sabido que o teor zero, ou próximo de, é geralmente impossível. Supondo que uma empresa seja obrigada, legalmente, a restaurar uma área contaminada por suas atividades, devendo eliminar X\% dos resíduos ali depositados, ao decidir eliminar X\% + 1 dos resíduos estará assumindo, espontaneamente, uma obrigação que supera os requisitos legais, tratando-se, portanto, de uma obrigação construtiva. Isto ocorrerá nos casos em que a empresa, imbuída de uma consciência de responsabilidade social, esteja disposta a usar todos os meios necessários e disponíveis para proporcionar o bem-estar da comunidade circunvizinha. Ou, então, se estiver preocupada com sua reputação na comunidade externa em geral;

- justas (equitable): estas refletem as obrigações que a empresa se vê obrigada a cumprir por fatores éticos e morais, independentemente de lei. Aqui, tem-se claramente definida a questão da consciência de responsabilidade social, ou preocupação com a reputação da empresa. Por exemplo, se não houver instrumento legal que obrigue uma determinada empresa a restaurar uma área contaminada por suas atividades, mas se tratando de fato relevante e se for de conhecimento público ou afetar interesses e direitos de terceiros, a empresa será compelida a reparar o erro cometido.

Para a ONU, o passivo ambiental se configura quando:

a) houver uma obrigação de a entidade prevenir, reduzir ou retificar um dano ambiental, sob a premissa de que a entidade não possui condições para evitar tal obrigação. Esta ausência de condições é definida pelas seguintes situações:

- i) existência de uma obrigação legal ou contratual;

- ii) política ou intenções da administração, prática do ramo de atividade, ou expectativas públicas; ou 
- iii) divulgação, por parte da administração, interna ou externamente, de sua decisão de prevenir, reduzir ou retificar o dano ambiental de sua responsabilidade.

b) o valor da exigibilidade pode ser razoavelmente estimado.

Os danos ambientais provocados pelas atividades operacionais da entidade, em propriedade própria ou de terceiros, desvinculados de qualquer obrigação legal de retificação, deverão constar em notas explicativas, com destaque para a extensão do dano e uma estimativa razoável do montante que poderá ser exigido.

Quando houver dificuldade para estimar o total do passivo ambiental, poderá ser feita uma estimativa razoável. Esta pode ser baseada em informações sobre séries de perdas possíveis, sendo usada a melhor das alternativas apresentadas. Experiências práticas anteriores poderão ser utilizadas para a determinação da estimativa. Novos conhecimentos sobre técnicas e legislação deverão ser considerados; contudo, vale ressaltar que desenvolvimentos tecnológicos em andamento, que não possam ser comprovados, não deverão ser levados em conta.

O total registrado como exigibilidade deverá ser uma estimativa do montante total da expectativa de gastos ambientais futuros (ou a melhor estimativa, se o montante atual não for conhecido), devendo ser decorrente de transações ou eventos passados.

- A exigibilidade pode ser mensurada com base em estimativas de gastos que poderão ser exigidos para cumprir a obrigação no período corrente - método do custo corrente, ou com base no valor presente da estimativa dos gastos futuros, mas baseados em condições legais e/ou contratuais existentes (não em condições futuras) - método do valor presente. O método utilizado deverá ser evidenciado. 
- Se a exigibilidade for mensurada com base no valor presente da estimativa de gastos futuros, deve-se levar em consideração:

- a) a estimativa de gastos futuros baseada em custos correntes;

- b) o ajuste do montante:

- i) pela expectativa de inflação;

- ii) por avanços tecnológicos que estarão disponíveis para uso no curto prazo;

- c) o montante de ajustes deverá ser descontado, usando uma taxa de risco, a qual poderá ter como parâmetro as taxas dos títulos governamentais similares;

- d) nos casos em que há evidências de que obrigações adicionais serão incorridas em períodos futuros, a exigibilidade incremental deverá ser mensurada, usando uma taxa de risco que abranja todo o período. Uma taxa média ponderada de desconto poderá ser usada para mensurar a exigibilidade total;

- e) mudanças no valor presente da exigibilidade, devido à fluência do tempo, deverão ser reconhecidas como custo do período;

- f) modificação na estimativa de fluxo de caixa futuro, relativa ao cumprimento da exigibilidade, provocada por alterações em premissa e por novas exigências legais, deverá ser contabilizada como mudança em estimativa de exigibilidades; a taxa de desconto utilizada não poderá ser afetada.

A expectativa de recuperação de custos de natureza ambiental de terceiros não deve ser deduzida da exigibilidade, mas registrada separadamente como um ativo, a menos que haja um direito legal. Quando isso acontecer, o montante bruto de ambos - exigibilidade e recuperação - deverá ser evidenciado. 
Expectativa de lucros na venda da propriedade danificada ambientalmente e os produtos de "seguros" não deverão ser deduzidos da exigibilidade.

\section{3 - AJUSTE DE EXERCÍCIOS ANTERIORES}

$\mathrm{O}$ ajuste de exercícios anteriores foi inserido com o objetivo de delinear alguns pontos no que se refere ao exercício que receberá o registro contábil do mesmo.

Os ressarcimentos a terceiros por prejuízos ambientais provocados, as multas e as penalidades por infrações a legislações têm a origem do seu fato gerador no passado, normalmente em exercícios anteriores.

Apesar de as premissas contábeis determinarem o registro dos eventos e transações no momento em que ocorrem, não se deve alterar os resultados de exercícios já encerrados, em função de fatos não contabilizados na época devida, visto que as demonstrações contábeis já foram encerradas e que diversas decisões, entre os inúmeros usuários, foram tomadas com base nos resultados e situação patrimonial divulgados.

Surge, então, a figura da conta Ajustes de Exercícios Anteriores, do grupo do Patrimônio Líquido, a qual será utilizada em condições bastante restritas.

No Brasil, esta conta deve ser utilizada, apenas, para refletir:

- efeitos da mudança de critério contábil;

- retificação de erros de cálculos imputáveis a exercícios anteriores.

Estes eventos devem estar diretamente associados com as atividades desenvolvidas em um período contábil específico do passado, no qual ocorreu e foi reconhecido o benefício econômico. 
Este é, também, o tratamento preferencial recomendado pelo IASC (IAS 8), no que tange a casos gerais.

Nos EUA, de acordo com o FASB (FAS 16), a conta "ajustes de exercícios anteriores" somente deverá ser utilizada para a contabilização de efeitos da correção de erros de períodos anteriores, enquanto que os efeitos de mudanças de práticas, de forma geral, devem ser incluídos no exercício corrente.

Estas restrições se justificam pelas incertezas inseridas no nosso cotidiano, falhas de sistemas de informações e, algumas vezes, falta de agilidade destes. Estes problemas poderiam gerar significativos volumes de alterações de informações já divulgadas, daí a necessidade do estabelecimento de uma data-limite para entrada de dados na elaboração das demonstrações contábeis de cada período.

Além disso, tratando-se de questões ambientais, onde os efeitos não obedecem barreiras locais ou temporais, poderia ser bastante arbitrário afirmar que o exercício anterior a ser alterado seria o X ou o Y, ou ambos em proporções iguais. Imagine-se uma empresa que estivesse operando com base em tecnologia que a obrigava a emitir resíduos poluentes sobre a área circunvizinha, sendo que no decorrer dos últimos quatro anos tenha substituído gradualmente esta tecnologia por outras que eliminaram a emissão de poluição. No último ano, implantou mecanismos para recuperação das áreas fisicamente afetadas. $\mathrm{O}$ fato gerador dos gastos ocorreu no passado, mas qual foi o nível de degradação ao meio ambiente gerado em cada um dos períodos de atividade da companhia? Teria sido homogênea a distribuição ou teria havido alguma diferenciação entre a poluição emitida no processo de adaptação e início das operações da empresa e o processo operacional já normalizado? E se tiver ocorrido oscilações nos níveis de produção entre os períodos? Qual a parcela de custos que corresponderia à receita gerada em cada um deles? Qualquer resposta seria arbitrária. 
Há que se ressaltar que alguns eventos têm natureza passada, presente e futura, essencialmente quando se trata da continuidade da empresa; por exemplo, não poluir é uma condição importante por imposições do governo, do mercado e da sociedade. Desta forma, quer os gastos sejam utilizados para recuperar prejuízos provocados no passado, quer sejam usados para reduzir ou eliminar a poluição presente ou no futuro, estes estão sempre associados a benefícios econômicos futuros, os quais estão refletidos na possibilidade de a companhia continuar operando em conformidade com os padrões ambientais exigidos pelo mercado, governo e sociedade.

Em síntese, as modificações estruturais e conjunturais que alterem os níveis de riscos ambientais a que a empresa está sujeita, o conhecimento tardio de eventos e transações que afetem o valor dos registros contábeis de exercícios já encerrados e as penalidades por má conduta em períodos passados não devem ser contabilizados como Ajustes de Exercícios Anteriores, mas sim como resultados do exercício em curso.

\subsection{Posição do Canadá (CICA, 1992, p. 15)}

No Canadá, a conta de ajuste de exercícios anteriores poderá ser utilizada nos casos em que todas as quatro condições abaixo sejam atendidas:

a) os ajustes sejam específica e diretamente identificados com atividades de um determinado exercício anterior;

b) os ajustes não possam ser atribuídos a eventos econômicos ocorridos após a data de encerramento daquele exercício específico;

c) os fatos geradores sejam basicamente dependentes de decisões ou determinações alheias à administração ou seus proprietários;

d) os valores dos ajustes não podem ser razoavelmente estimados antes de tais decisões ou determinações. (tradução livre) 
Assim, para os canadenses, o uso da conta “Ajustes de Exercícios Anteriores" está condicionado ao atendimento de todos estes quesitos: conhecimento do período exato de sua ocorrência e da atividade que o gerou; exclusão dos efeitos de eventos econômicos que possam ser atribuídos a períodos presentes ou futuros; identificação das decisões não dependentes de ações da administração e dos valores não passíveis de provisões para reconhecimento de obrigações no devido regime de competência.

Sob tal ponto de vista, o uso da conta pode, ainda, ser justificado pelo "desconhecimento" de informações nas épocas devidas, ou má interpretação de tais informações.

Deste modo, em algumas situações o custo ambiental, conhecido no presente, pode ser registrado como ajuste de exercícios anteriores, com base no fato de que envolve a correção de um erro em demonstrações contábeis de períodos passados. O erro pode ser resultado de uma má interpretação, desconhecimento de uma informação disponível no momento em que as demonstrações contábeis estavam sendo preparadas, ou uma má apropriação dos custos dos ativos.

Por exemplo, se a análise de testes dos resíduos produzidos por uma empresa indicou que estes não tinham características poluentes, mas posteriormente constatou-se que as análises estavam erradas, o custo apurado no exercício atual pode ser registrado como ajuste de exercícios anteriores, com base no fato de que seria uma correção de um erro resultante de má interpretação da informação.

$\mathrm{Na}$ situação onde a empresa deixou de reconhecer os custos e a exigibilidade por desconhecer as características poluentes do seu processo operacional, mas teve conhecimento destas durante a existência de legislação que punia os poluidores, a regularização da situação se fará com um débito ao resultado do período em curso. Porém, no Canadá, diante da hipótese de a empresa desconhecer suas características poluentes, admite-se a utilização da conta de ajuste de exercícios anteriores. Trata-se de uma hipótese de natureza questionável, em face da dificuldade de se provar que a empresa desconhecia a 
poluição gerada por seu processo operacional, quando já existia regulamentação sobre o assunto.

Nos casos de gastos com reparos, recuperação ou restauração, provenientes da instituição de uma nova legislação, o débito é devido ao resultado do exercício em curso, por ser decorrente de evento ocorrido em período subseqüente àquele em que ocorreu o fato gerador.

As estimativas devem ter por base estudos técnicos relativos ao impacto ambiental provocado pelas atividades da empresa e os recursos necessários para reverter tais impactos.

Nas situações em que a empresa, mesmo conhecendo a natureza poluente de suas atividades, deixa de reconhecer, no período de incorrência, o custo com disposição e tratamento dos resíduos poluentes gerados por suas atividades - e, conseqüentemente, de constituir a provisão para fazer face aos gastos necessários, ainda que com base em estimativas -, na regularização da situação, em períodos posteriores, não deverá ser utilizada a conta de ajuste de exercícios anteriores e, sim, o resultado do exercício em curso. Isto porque a empresa dispunha de informações sobre as características poluentes do seu processo operacional.

É diferente a situação em que, graças aos avanços científicos da atualidade, se constata que a empresa esteve produzindo poluição em períodos passados. No momento da produção, aquele resíduo era considerado inofensivo; seu poder de destruição e/ou deterioração do meio ambiente foi descoberto depois. Neste caso, a identificação dos custos ambientais e da necessidade de incorrer em gastos para recuperação e/ou restauração se deve a eventos subseqüentes ao momento em que o fato gerador ocorreu. Desse modo, a regularização da situação se fará com um débito ao resultado do exercício em curso, porque a identificação do fato deve-se a um evento ocorrido após o encerramento do exercício social (avanço científico) e porque não houve erro de cálculo ou mudança de critério contábil. 
Caso a empresa tenha reconhecido o custo no devido período de competência, em contrapartida a uma provisão de gastos, e esta se mostrar insuficiente para cobrir os custos reais, o complemento deve ser registrado no resultado do exercício em curso.

A correção de um erro, como os retromencionados, é diferente de mudanças nos valores provisionados com base em estimativas. Um valor pode ser estimado como parte de um processo contábil normal, o qual é vulnerável a eventos subseqüentes; isto não se constitui em um erro de cálculo. A alteração em uma estimativa contábil resulta de novas informações, mais experiência ou desenvolvimentos subseqüentes.

\subsection{Posição da ONU (UN-ISAR, 1997, p. 30)}

Partindo do fato de que em alguns casos os gastos ambientais podem estar relacionados a danos que ocorreram no passado, e do questionamento quanto à sua correta classificação contábil, a ONU determina que os custos relativos aos danos ambientais incorridos em períodos passados devem ser reconhecidos no resultado do período em que se tornarem conhecidos. Não devem ser tratados como ajustes de exercícios anteriores, a menos que satisfaçam aos restritivos critérios estabelecidos pelos padrões contábeis para uso da conta de ajuste de exercícios anteriores.

O ICAEW - Institute of Chartered Accountants in England and Wales, também citado pela ONU (UN-ISAR, 1997, p. 23), observa que ajustes de períodos anteriores são definidos como "ajustes materiais aplicáveis a períodos passados, em decorrência de mudanças em políticas contábeis e da correção de erros fundamentais. Normalmente, não se inclui ajustes repetitivos ou correção de estimativas contábeis, constituídas em períodos anteriores." (tradução livre) 


\section{4 - CUSTOS/ DESPESAS/PERDAS ESPECÍFICOS DA ÁREA AMBIENTAL}

Custos e despesas são, em termos gerais, gastos utilizados para a condução das atividades da empresa. Contudo, considerar-se-á custos como os gastos relacionados com o processo operacional em si e as despesas como aqueles gastos inerentes à área administrativa como um todo.

Muitos gastos da empresa na área ambiental resultam em benefícios econômicos futuros para a sociedade externa, como resultado de um meio ambiente melhor ou pela conservação de recursos naturais; porém, não necessariamente refletirão expectativas de benefícios futuros para a entidade que incorreu nos gastos, mas apenas despesas do período.

\subsection{Custos Ambientais}

Os custos ambientais devem compreender todos aqueles relacionados, diretamente ou indiretamente, com a proteção do meio ambiente, como:

- todas as formas de amortização (depreciação, amortização e exaustão) dos valores relativos aos ativos de natureza ambiental possuídos pela companhia;

- aquisição de insumos próprios para controle/redução/eliminação de poluentes;

- tratamento de resíduos dos produtos;

- disposição dos resíduos poluentes;

- tratamentos de recuperação/restauração de áreas contaminadas;

- mão-de-obra utilizada nas atividades de controle/preservação/recuperação do meio ambiente.

A ONU (UN-ISAR, 1997, p. 1) ressalta que os limites dos custos não são estáticos. Legislações e novas metodologias de mensuração podem impor obrigações às empresas 
para empreender ações específicas, para as quais não havia, anteriormente, qualquer exigência. Segundo a Entidade, custos ambientais incluem os gastos realizados para:

- prevenir, reduzir ou reparar danos ao meio ambiente, danos estes resultantes das atividades operacionais da empresa, ou necessários à conservação de recursos renováveis ou não-renováveis;

- disposição de refugos, ou para evitá-los; proteção de águas; preservação ou melhoria da qualidade do ar; redução de barulho; remoção de contaminação de prédios; pesquisa para desenvolvimento de produtos, matéria-prima ou processo de produção ambientalmente saudáveis etc.

O Canadian Research Report (UN-ISAR, 1997, p. 3) define como custos ambientais:

- a) os custos de mensuração ambiental (aqueles relacionados à prevenção, redução, reparação de danos ao meio ambiente);

- b) perdas ambientais;

- c) multas, penalidade e compensação para terceiros.

A Entidade exclui os custos relacionados a atividades de segurança.

O CICA (UN-ISAR, 1997, p. 3), em seu pronunciamento "Task Force on Environmental Liabilities and Costs", definiu custos ambientais como aqueles incorridos:

- para prevenir, remover, conter ou retificar danos ao meio ambiente;

- para auxiliar na preservação ou conservação do meio ambiente; ou

- como resultado de atividades, ou ausência destas, que danifiquem o meio ambiente. (tradução livre)

Assim, semelhantemente ao Canadian Research Report, o CICA Task Force considera multas, penalidades e compensações a terceiros, relativos à área ambiental, como custos ambientais, desde que resultem de atividades, ou ausência destas, que danifiquem o meio ambiente. O Pronunciamento apresenta como exemplos de custos ambientais: a restauração de locais de minas, depois da conclusão das operações destas (retificação de danos ao meio 
ambiente); estudos técnicos para identificação, avaliação e controles de monitoramento para manutenção dos padrões de conformidade ambiental.

O CICA Task Force observa que os custos de atividades ambientais, diretamente empreendidos por empregados da entidade, somente poderão ser classificados como tal à medida que sejam elementos essenciais à área ambiental e incorridos em substituição aos serviços de terceiros. Ressalte-se, ainda, que alguns custos podem ser parcialmente de natureza ambiental. Por exemplo, uma parte do equipamento pode ser adquirida para ambos: auxiliar a retificação, estabilização ou contenção de danos ao meio ambiente e melhorar a eficiência total do negócio. Nesse caso, é preciso fazer uma análise do custo/benefício da identificação e segregação do custo ambiental.

A divergência básica entre as Organizações que têm estudado o tratamento contábil dos eventos e transações relacionados com a área ambiental é quanto à classificação, como custos ambientais, das multas, penalidades e compensações a terceiros, referente às atividades ambientais, ou ausência destas.

Enquanto a EAAF (European Accounting Advisory Forum) e a ONU as excluem, o ICAEW (Institute of Chartered Accountants in England and Wales) não tomou uma posição, mas não concorda com a exclusão. No Canadá, tanto o CICA como o Canadian Research Report incluem tais itens como custos ambientais.

Qualquer que seja a definição de gastos ambientais adotada, parece que haverá sempre áreas cinzentas, onde o exercício do julgamento é necessário para decidir sobre quais gastos se qualificam como ambientais.

\subsubsection{Custos Relacionados Diretamente aos Benefícios do Período em Curso}

Os custos ambientais que podem ser claramente associados com os benefícios recebidos no período corrente e que serão debitados ao mesmo incluem, basicamente, os custos de operacionalização dos sistemas de proteção ambiental. 


\subsubsection{Custos Relacionados Indiretamente aos Benefícios do Período em Curso}

Os custos ambientais que tenham uma relação indireta com os benefícios do período em curso incluem os custos de:

- administração do controle ambiental, custos de adequação do processo operacional e de auditoria;

- treinamento;

- pesquisas que não podem ser associadas com benefícios futuros específicos, iniciadas com o objetivo de prevenir e reduzir danos ao meio ambiente, ou conservação de recursos naturais;

- programas de reciclagem.

\subsubsection{Gastos com Pesquisa e Desenvolvimento}

Os gastos com pesquisa e desenvolvimento podem ocorrer em função de preocupações ambientais, seja no desenvolvimento de novos produtos, ou de novos processos.

Tais gastos devem ser "apropriados diretamente no resultado do período em que forem incorridos, a menos que possa ser feita uma correspondência com as respectivas receitas de futuros períodos, com razoável segurança.” (IUDÍCIBUS at alii, 1995, p. 325)

Segundo as conclusões do Grupo de Trabalho Intergovernamental de Especialistas em Padrões Internacionais de Contabilidade para Corporações Internacionais, editado pela ONU em 1988:

“É reconhecido que os gastos com pesquisa e desenvolvimento podem ser capitalizados, se todos os seguintes critérios forem satisfeitos: 
- a) o produto ou processo é claramente definido e os custos atribuíveis ao produto ou processo podem ser identificados separada e claramente;

- b) a viabilidade técnica do produto ou processo está demonstrada;

- c) há clara indicação do mercado futuro para o produto ou processo, ou destina-se a uso interno em vez de venda, sua utilidade à empresa pode ser demonstrada;

- d) a gerência da empresa indicou sua intenção de produzir e vender, ou usar o produto ou processo;

- e) existem adequados recursos, ou há expectativa razoável de sua disponibilidade, para completar o projeto e a comercialização ou uso do produto ou processo." (IUDÍCIBUS, et alii, 1995, p. 325)

A posição do Canadá é de que somente os gastos com desenvolvimento podem ser diferidos. O CICA define desenvolvimento como a transição da pesquisa finda para um novo plano ou modelo que propicie substanciais melhoras de materiais, recursos, produtos, processos, sistemas ou serviços, transição esta que se encerra com o início da produção comercial ou uso. Esta é também a posição adotada nos EUA (FAS 9).

\subsection{Despesas Ambientais}

Considera-se como despesas ambientais todos os gastos envolvidos com o gerenciamento ambiental, consumidos no período e incorridos na área administrativa. Qualquer empresa necessita dos serviços de um departamento de recursos humanos, ou do de compras, financeiro, de recepção e almoxarifado, e estas áreas desenvolvem atividades inerentes à proteção do meio ambiente.

As despesas ambientais podem conter gastos relativos a horas de trabalho (e seus respectivos encargos sociais) e insumos absorvidos:

- na definição e manutenção de programas e políticas ambientais;

- na seleção e recrutamento de pessoal para o gerenciamento e operação do controle ambiental; 
- na compra de insumos e equipamentos antipoluentes;

- no pagamento das compras realizadas para a área ambiental;

- na recepção dos itens ambientais adquiridos;

- para a estocagem dos insumos utilizados no controle ambiental;

- em treinamentos específicos para a proteção ambiental;

- na auditoria ambiental.

Estes gastos devem ser contabilizados como despesas do exercício em curso; embora alguns possam ter relações com benefícios futuros, dificilmente estes poderiam ser claramente associados ou mensurados.

Tanto custos como despesas relativos à proteção ambiental não ocorrem em uma área isolada. É preciso investigar cada uma das unidades de trabalho da empresa para identificar onde são realizadas atividades inerentes à proteção ambiental.

\subsection{Perdas Ambientais}

Perdas refletem os gastos incorridos sem uma contrapartida em benefícios. Portanto, perdas ambientais são os gastos que não proporcionam benefícios para a empresa. As perdas podem receber a classificação de normal e anormal. Normais são aquelas previsíveis e de montantes previamente definidos como aceitáveis. Anormais são as não esperadas e de volumes relevantes. As perdas normais são geralmente incluídas nos custos do processo operacional, na maioria das vezes sem uma segregação, visto que o custo não justificaria o benefício gerado pela informação segregada. As anormais são, via de regra, classificadas como resultado não operacional, com segregação específica, tais como:

- gastos que não trazem qualquer benefício adicional:

- multas ou penalidades por inadequação das atividades à legislação;

- restauração de áreas contaminadas (próprias ou de terceiros); 
- complemento da estimativa dos custos de recuperação relacionados a atividades de períodos anteriores.

Assim, pode-se ter:

\section{Na área administrativa:}

$\checkmark$ Departamento de Gerenciamento Ambiental:

- Investimentos ambientais de natureza permanente: móveis e utensílios, os quais darão origem à depreciação de imobilizados de natureza ambiental.

- Despesas Ambientais Operacionais:

- salários,

- depreciação,

- material de escritório etc.

$\checkmark$ Departamento de Recursos Humanos:

- Despesas Ambientais Operacionais:

- quantidade de horas trabalhadas/insumos consumidos na seleção, recrutamento, treinamento de pessoal da área ambiental.

$\checkmark$ Departamento de Compras

- quantidade de horas trabalhadas/insumos consumidos na pesquisa, seleção e aquisição de itens necessários à área ambiental.

$\checkmark$ Departamento Financeiro

- quantidade de horas trabalhadas/insumos consumidos na pagamento de aquisições e serviços prestados à área ambiental. 


\section{Na área operacional:}

- Investimentos Ambientais de natureza permanente:

- máquinas e equipamentos antipoluentes, os quais darão origem à depreciação de itens de natureza ambiental.

- Custos Ambientais Operacionais:

- horas de mão-de-obra,

- horas-máquina,

- depreciação,

- matéria-prima,

- insumos diversos etc.

Portanto, o consumo de recursos destas áreas (administrativas e operacional) representa os gastos relativos ao controle ambiental, os quais devem ser segregados entre:

- investimentos ambientais de natureza permanente;

- custos ambientais operacionais; e

- despesas ambientais operacionais.

\section{5 - EVIDENCIAÇÃO}

O que, como, quando e onde evidenciar?

- O que: todas as informações relativas aos eventos e transações envolvidos com a questão ambiental.

- Como: com o grau de detalhamento exigido pela relevância dos valores e da natureza dos gastos, relativos à interação entre a empresa e o meio ambiente. 
- Quando: o registro contábil deverá ser feito no momento em que o fato gerador ocorrer, ou no momento em que houver informações adicionais e complementares

- Onde: No corpo das demonstrações contábeis e nas notas explicativas, dependendo da extensão e natureza das informações a serem prestadas.

\subsection{Políticas da Entidade Pertinentes ao Meio Ambiente}

Por meio de notas explicativas ou relatórios da administração, a empresa deverá informar quais são suas diretrizes ambientais, incluídas entre as políticas da entidade, como:

- comprometimento da empresa com as questões ambientais;

- impacto de suas operações sobre o meio ambiente;

- estágio de adaptação de seu processo operacional a condições ambientalmente saudáveis;

- medidas adotadas para reduzir/eliminar efeitos negativos;

- tratamento contábil dado aos gastos de natureza ambiental:

- o que está incluído na definição de custos ambientais, se esta existir;

- critérios utilizados para classificação dos gastos ambientais como despesas, custos ou elementos do patrimônio da companhia;

- regras utilizadas para definir formas de amortização do valor dos ativos ambientais;

- normas usadas para reconhecimento das exigibilidades ambientais.

De acordo com a ONU (UN-ISAR, 1997, p. v):

- Qualquer política contábil que seja especificamente referente a exigibilidades ambientais e custos deverá ser evidenciada. 


\subsection{Ativos Ambientais}

Os ativos ambientais devem ter classificação, controle e divulgação destacada nos grupos do ativo. Tratando-se de publicação de demonstrações contábeis, sua participação em cada grupo deve ser informada de forma sintetizada, em notas explicativas.

A natureza e finalidade dos ativos ambientais devem ser informados nas notas explicativas, essencialmente quando houver novas aquisições.

Os gastos adicionais ao custo de aquisição, agregados ao valor do ativo, devem ser evidenciados no exercício em que a incorporação ocorrer, juntamente com a justificativa de sua razão de ser.

\subsection{Passivos Ambientais}

Os passivos ambientais devem ser informados em subgrupo específico das exigibilidades. A composição das exigibilidades de natureza ambiental e respectivos valores deverão ser discriminados em notas explicativas às demonstrações contábeis.

Quando da existência de uma obrigação relevante, quanto ao valor e natureza, esta deverá ser contabilizada e evidenciada no Balanço Patrimonial em conta específica.

Obrigações de natureza ambiental, não passíveis de mensuração, devem constar das notas explicativas, bem como a razão pela qual não podem ser mensuradas, essencialmente quando houver alto grau de probabilidade de sua efetiva exigibilidade, e o momento em que se espera quitar esta obrigação.

A existência de riscos futuros de natureza ambiental deve ser objeto de destaque, com a abrangência e profundidade proporcionais ao grau de risco. 
A expectativa de gastos futuros ou perdas, ambas de natureza ambiental, cuja realização seja considerada como não provável, mas que, se acontecerem, podem ter impacto significativo sobre o patrimônio da empresa, especialmente seu fluxo de caixa, deve ser objeto de notas explicativas, devendo ser destacados:

- a natureza e estimativa da expectativa de gastos ambientais;

- incertezas relativas à sua realização;

- momento da possível realização.

De acordo com a ONU (UN-ISAR, 1997, p.v):

- as exigibilidades ambientais devem ter uma legenda separada nas demonstrações contábeis, e nas notas explicativas deverão ser evidenciadas:

- a base, ou bases, utilizadas para mensurar a exigibilidade ambiental (por exemplo, o "custo corrente aproximado" ou o "valor presente aproximado)";

- para cada categoria de exigibilidades materiais:

- a) uma breve descrição da natureza da exigibilidade;

- b) uma indicação geral do tempo e termos utilizados para sua determinação;

- c) o montante e vencimento da exigibilidade, quando houver significativa incerteza.

- todas as premissas críticas para estimar as futuras saídas de caixa e as exigibilidades, reconhecidas nas demonstrações contábeis, quando o "valor presente aproximado" tiver sido usado como base para mensuração, destacando:

- a) o custo corrente estimado da exigibilidade;

- b) a estimativa de longo prazo para a taxa de inflação usada no cômputo da exigibilidade;

- c) a estimativa do custo futuro; 
- d) a taxa de desconto.

- a natureza das exigibilidades ambientais reconhecidas nas demonstrações contábeis, incluindo, também, uma breve descrição de quaisquer danos ambientais, quaisquer leis ou regulamentações que requeiram restauração e alteração proposta nas referidas leis ou nas tecnologias existentes;

- as características ambientais da entidade e seu segmento:

- i) a política formal e programas que tenham sido adotados pela entidade;

- ii) nos casos onde tais políticas e programas existam, o fato deve ser declarado;

- iii) as melhorias em áreas-chave que tenham sido feitas, desde a introdução destas políticas ou nos últimos 5 anos, o que for mais curto;

- iv) em que nível os trabalhos de proteção ambiental foram realizados, tendo em vista a legislação governamental e seus resultados (por exemplo, volume de redução de emissões);

- v) quaisquer procedimentos materiais sobre leis ambientais.

- qualquer incentivo governamental, tais como concessões e incentivos fiscais fornecidos para a proteção ambiental. (tradução livre)

\subsection{Custos Ambientais}

Os custos ambientais de montante e/ou natureza relevantes, computados na Demonstração de Resultados do Exercício, de forma agregada, devem ser discriminados, por natureza, nas notas explicativas.

Variações das estimativas de custos ambientais anteriores devem ser justificadas, bem como informado o nível de riscos de oscilações esperado sobre as provisões constituídas no exercício. 
De acordo com a ONU (UN-ISAR, 1997, p. iv-v) deverão ser evidenciados:

- a definição de custos ambientais;

- o montante do gasto ambiental contabilizado no resultado, discriminando, de maneira apropriada, a natureza e sua extensão no negócio, além de incluir uma breve descrição de quaisquer danos ambientais, leis ou regulamentações que requeiram restauração e qualquer alteração proposta nessas leis ou nas tecnologias existentes.

\subsection{Perdas Ambientais}

A expectativa de perda de ativos, parcial ou total, provocada por razões de natureza ambiental, e sua justificativa, deve ser evidenciada, em notas explicativas, bem como, se possível, os valores envolvidos.

Outras perdas ambientais previsíveis também devem ser justificadas.

As perdas efetivas, de valores relevantes, devem, igualmente, ter suas origens explicitadas em notas explicativas.

Sob o ponto de vista da ONU (UN-ISAR, 1997, p. v):

- Gastos incorridos com multas e penalidades, por não conformidade com regulamentações ambientais e compensações a terceiros, como resultado de perdas ou danos causados por poluição no passado, deverão ser evidenciados;

- Quaisquer custos ambientais registrados como itens extraordinários deverão ser evidenciados separadamente. 


\section{IV - GESTÃO AMBIENTAL E SEUS ASPECTOS ECONÔMICOS}

Este capítulo descreve as orientações básicas determinadas pela ISO 14000 para a implementação de um sistema de gerenciamento ambiental e os aspectos econômicofinanceiros inerentes a este.

\section{1 - GERENCIAMENTO AMBIENTAL}

A Inglaterra, mediante a BS 7750, foi o primeiro país a emitir normas para orientação da gestão ambiental pelas empresas. Esta norma teve ampla aceitação em países da Europa e foi utilizada como instrumento-base para a elaboração da ISO 14000. (GILBERT, 1995, p. v)

A ISO 14000 (e suas subséries) foi elaborada recentemente (conclusão parcial em 1996), pela International Standards Organization - ISO. Esta norma define os padrões internacionais de gerenciamento ambiental que devem ser seguidos por todas as empresas, notadamente por aquelas que apresentam grande potencial de poluição.

Com isso, tem-se um padrão que deve homogeneizar o comportamento e as ações das empresas sobre a interação com o ambiente natural, no qual haverá o consumo dos produtos e descarte final de seus restos. Espera-se que este padrão seja aplicado no controle dos resultados, do desenvolvimento das atividades econômicas e dos seus produtos.

As empresas empenhadas na inevitável e necessária tarefa de proteger o meio ambiente devem incluir, na definição de sua missão e em sua política global, as diretrizes básicas para com o meio ambiente. A título de exemplo, apresentamos as políticas ambientais declaradas por duas empresas (HOJDA, 1997, p. 103-104): 
Hering Têxtil:

"Nós, Hering Têxtil S.A., continuaremos a desenvolver uma organização têxtil inovadora e sustentável, fornecendo a nossos clientes nacionais e estrangeiros produtos da mais alta qualidade ambiental e tecnológica, promovendo em nossas atividades industriais os seguintes princípios da gestão ambiental da qualidade total:

1. Compromisso pleno com a qualidade ambiental...;

2. Melhoria Contínua...;

3. Redução de Riscos...;

4. Incentivar Contratados e Fornecedores...;

5. Responsabilidade e Integridade...;

6. Prevenção da Poluição...;

7. Educação e Motivação...;

8. Transparência e Comunicação...”

Bahia Sul:

"É nosso compromisso conduzir as ações da empresa orientadas pelo conceito de desenvolvimento sustentável e apoiadas nos seguintes princípios:

- Reconhecimento da gestão do meio ambiente como uma de nossas prioridades;

- Contribuição para o desenvolvimento do ser humano, para que ele possa atuar de forma ambientalmente responsável;

- Aperfeiçoamento contínuo dos processos, produtos e serviços, visando a melhoria constante do desempenho ambiental e a prevenção da poluição;

- Observância das legislações relativas ao meio ambiente;

- Diálogo com as partes interessadas sobre nossas atividades e seus efeitos ambientais. 
O nosso Sistema de Gerenciamento Ambiental abrange o complexo industrial, com todas as etapas de fabricação de celulose e papel, e a área de recursos naturais, incluindo os seus núcleos operacionais.

Os objetivos e metas da organização são anualmente atualizados e publicados no informativo oficial da empresa, ficando disponíveis para consultas pelas partes interessadas, nas áreas de Comunicação e Garantia de Qualidade.”

Estando definidas as políticas e estabelecida a postura da empresa em relação ao meio ambiente, faz-se necessário determinar as estratégias e modo operacional para atingir tal missão, agora com um escopo mais amplo.

Estratégica e operacionalmente, para que a empresa execute efetivamente o seu compromisso de respeitar o meio ambiente é necessário que cada uma das suas áreas de trabalho esteja comprometida com este propósito e, conseqüentemente, cada um de seus colaboradores.

Em grandes empresas, considerando suas dimensões e multiáreas de trabalho internas e externas, é conveniente a criação de uma área de trabalho (ou departamento) específico para planejar, orientar a execução e controlar as políticas ambientais adotadas pela Empresa. Este departamento deve ter acesso direto à alta administração, representando uma linha específica de atribuições da Organização.

DONAIRE $(1995$, p. 65 e 66) aborda as variações das estruturas organizacionais de controle ambiental, entre as diversas empresas, da seguinte forma:

"A maneira pela qual a atividade/função ecológica deve ser estruturada depende do tipo de atividade a que a empresa se dedica e do tamanho da empresa. Em função de seu ramo industrial, poderá haver maior ou menor envolvimento com a questão ambiental e, portanto, isso se traduzirá em arranjos organizacionais diferenciados, seja em nível das 
atividades/responsabilidades relativas a sua área de atuação, seja no exercício de sua autoridade e mesmo no entrosamento e na comunicação dessa atividade/função com as demais funções organizacionais. Nas pequenas empresas e mesmo em muitas empresas médias não existe uma atividade específica que cuida do meio ambiente, entendendo-se que isto deve ficar por conta do responsável pelo processo produtivo que, em última análise, deve ter a responsabilidade pelos danos que seus efluentes podem causar ao meio ambiente."

A existência de uma diretoria e um departamento ambiental não implica que todas as atividades de proteção ambiental sejam executadas isoladamente; muito pelo contrário, essas atividades se desenvolvem em cada segmento da empresa: na área administrativa, de produção, de recepção, de expedição etc. Dependendo das características da companhia, pode haver um alto volume de atividades concentrado na área de produção. Em síntese, o departamento responsável pela proteção ambiental elabora o planejamento e informa às demais áreas o que deve ser executado. $\mathrm{O}$ controle cabe às próprias áreas e também ao departamento ambiental, essencialmente quanto à investigação de desvios relevantes.

É crescente o número de empresas que têm instituído a diretoria e o departamento de proteção ambiental, essencialmente na última década. Algumas os incorporaram a departamentos já existentes, como o de produção, de segurança, ou de qualidade. Muitas adotaram sistemas de gerenciamento ambiental, ainda que em quantidades e procedimentos bastante tímidos.

Nem todos os sistemas de gerenciamento ambiental têm as características daquele recomendado pelo ISO 14000 (e suas subséries); muitos ainda são personalizados, conforme as diretrizes auto-estabelecidas pelas empresas, em face da diversidade de atividades econômicas e ausência de normatização geral obrigatória

Sabendo-se que esta nova área da organização - gerenciamento ambiental - consome recursos físicos, humanos e financeiros, necessário se faz a apuração, controle e avaliação 
de seus resultados e desempenho. Ou seja, trata-se de uma unidade da empresa que deve ser, tal qual as demais, controlada sob o aspecto financeiro e econômico, dado que, em nível maior ou menor, tem impacto sobre a gestão econômica da empresa como um todo.

Este controle deve ocorrer tanto sobre o departamento em si como sobre as decisões emanadas deste para as demais áreas de trabalho. Estas devem ser mensuradas física e monetariamente, a fim de se apurar o resultado físico e técnico da atividade operacional e o volume de gastos da empresa na proteção ambiental.

\section{2 - ISO 14000 (e suas subséries) - SISTEMA DE GESTÃO AMBIENTAL (ABTN, 1996) E SUA INTERAÇÃO COM A GESTÃO ECONÔMICA DA EMPRESA}

A denominação da norma ISO 14000 (e suas subséries) será simplificada, neste tópico, para ISO 14000. Não se entrará no mérito de cada subsérie, cuidando-se apenas dos aspectos globais do conjunto.

A ISO 14000, como antes afirmado, estabelece as diretrizes básicas para a implementação do sistema de gestão ambiental o qual constitui. um processo estruturado, genérico e completo, que visa a melhoria contínua do desempenho em relação à área ambiental nas empresas, e globalmente. O simples ato de se adotar tal sistema não implica que (e nem permanentemente) todos os problemas de natureza ambiental de uma Organização estejam resolvidos; faz-se necessário um processo contínuo de acompanhamento e manutenção do mesmo, por meio de revisões, análises e avaliações periódicas dos procedimentos instituídos, viabilizando a identificação de oportunidades de melhorá-lo sempre.

A Norma é aplicável a qualquer tipo de empresa. Sua implementação total, parcial ou gradativa pelas companhias dependerá das políticas ambientais adotadas, da natureza das suas atividades, potencial de produção de poluição da atividade e distribuição deste entre as áreas internas, porte da organização, condições financeiras etc. Este conjunto de fatores é 
que definirá o nível de detalhamento e complexidade do sistema de gestão ambiental, a amplitude da documentação e os recursos necessários.

Conforme os padrões adotados pela ISO 14000 (ABTN, 1996, p. 4), o sistema de gestão ambiental compreende "a parte do sistema de gestão global que inclui estrutura organizacional, atividades de planejamento, responsabilidades, práticas, procedimentos, processos e recursos para desenvolver, implementar, atingir, analisar criticamente e manter a política ambiental."

Para REIS (1995, p. 10), "Gerenciamento Ambiental é um conjunto de rotinas e procedimentos que permite a uma organização administrar adequadamente as relações entre suas atividades e o meio ambiente que as abriga, atentando para as expectativas das partes interessadas,...e que objetiva, dentre suas várias atribuições, identificar as ações mais adequadas ao atendimento das imposições legais aplicáveis às várias fases dos processos, desde a produção até o descarte final, passando pela comercialização, zelando para que os parâmetros legais sejam permanentemente observados, além de manter os procedimentos preventivos e proativos que contemplam os aspectos e efeitos ambientais da atividade, produtos e serviços e os interesses e expectativas das partes interessadas."

Existe, portanto, a necessidade de investimento para capacitação da mão-de-obra nos vários níveis envolvidos e para a aquisição de tecnologias adequadas. A decisão de investimentos envolve as áreas operacionais, econômica e financeira.

A norma ISO 14000 não define critérios específicos de desempenho ambiental, mas discrimina os requisitos norteadores da formulação de políticas e objetivos, quanto aos aspectos ambientais controláveis ou passíveis de serem influenciados, visando atender às especificações legais e propiciar informações sobre os impactos ambientais de natureza relevante, aplicável às empresas que objetivem:

- “a) implementar, manter e aprimorar um sistema de gestão ambiental;

- b) assegurar-se de sua conformidade com sua política ambiental definida; 
- c) demonstrar tal conformidade a terceiros;

- d) buscar certificação/registro do seu sistema de gestão ambiental por uma organização externa;

- e) realizar uma auto-avaliação e emitir autodeclaração de conformidade com esta Norma." (ABTN, 1996, p. 3)

A ISO 14000, enquanto sistema de gerenciamento ambiental, define alguns termos, os quais encontram perfeito paralelo com a gestão econômica da empresa, tais como os itens abaixo:

\section{“3.1}

\section{melhoria contínua}

processo de aprimoramento do sistema de gestão ambiental, visando atingir melhorias no desempenho ambiental global de acordo com a política ambiental da organização.”

O processo de gestão econômica da empresa objetiva, primordialmente, atingir a missão a que a empresa se propôs. Para tal, é preciso que a continuidade desta seja garantida, a qual, por sua vez, exige melhorias contínuas, no sentido de acompanhar as evoluções do mercado. As melhorias contínuas somente serão possíveis se houver recursos econômicos e financeiros. A existência destes e seu correto 'balanceamento' garantem o alcance da missão da empresa. "A gestão econômica se ocupa dos aspectos econômicos das decisões operacionais, isto é, se ocupa da gestão dos recursos consumidos, do valor agregado pelo processo e do valor do bem produzido, visando à otimização do resultado econômico...." (NOGUEIRA, 1993, p. 143)

\section{'3.4}

\section{impacto ambiental}

qualquer modificação do meio ambiente, adversa ou benéfica, que resulte, no todo ou em parte, das atividades, produtos ou serviços de uma organização." 
Sob os aspectos da gestão econômica, os impactos ambientais estão estreitamente associados ao surgimento dos passivos ambientais, da necessidade de aquisição de tecnologias antipoluentes, da perda de potencial econômico dos ativos ou do desperdício de recursos e tempo que poderiam melhorar o resultado operacional.

\section{“3.7}

\section{objetivo ambiental}

propósito ambiental global, decorrente da política ambiental, que uma organização se propõe a atingir, sendo quantificado sempre que exeqüível."

De acordo com as premissas da gestão econômica da empresa, seu objetivo ambiental deve ser quantificado física e monetariamente, de forma a fornecer subsídio completo para análise e avaliação dos esforços empreendidos no sentido de atingi-lo.

\section{'3.8}

\section{desempenho ambiental}

resultados mensuráveis do sistema de gestão ambiental, relativos ao controle de uma organização sobre seus aspectos ambientais, com base na sua política, seus objetivos e metas ambientais."

Sob o ponto de vista da gestão econômica, todas as unidades de trabalho devem ter seus resultados mensurados física e monetariamente, para efeito de avaliação do desempenho e dos resultados.

\section{“3.9}

\section{política ambiental}

declaração da organização, expondo suas intenções e princípios em relação ao seu desempenho ambiental global, que provê uma estrutura para ação e definição de seus objetivos e metas ambientais." 
Sob a visão da gestão econômica, a política ambiental do gerenciamento ambiental deve ser reflexo da cultura organizacional (crenças e valores) adotada pela empresa.

\section{'63.10}

\section{meta ambiental}

requisito de desempenho detalhado, quantificado, sempre que exeqüível, aplicável à organização ou partes dela, resultante dos objetivos ambientais e que necessita ser estabelecido e atendido para que tais objetivos sejam atingidos."

Sob o ponto de vista da gestão econômica, os resultados esperados devem ser orçados para balizar os procedimentos operacionais, servindo, posteriormente, para avaliação dos resultados reais.

\subsection{Da Implementação, Manutenção e Controle}

O sistema de gestão ambiental estabelecido pela ISO 14001 possui requisitos de implementação e manutenção similares a um sistema de gestão global de uma organização, quais sejam:

\begin{tabular}{|lll|}
\hline GESTÃO AMBIENTAL & GESTÃO GLOBAL \\
política ambiental & Política global \\
planejamento & & Planejamento estratégico \\
implementação e operação $\Rightarrow$ & Planejamento operacional \\
& $\stackrel{\leftrightarrow}{\rightarrow}$ & Execução \\
verificação e ação corretiva & Controle \\
\hline
\end{tabular}




\subsubsection{Política Ambiental}

A política ambiental deve refletir o compromisso da alta administração em atender à normatização legal e obter a melhoria contínua, tendo como base os objetivos e metas da empresa.

\subsubsection{Planejamento}

Sob a ótica da gestão econômica de recursos da empresa, o planejamento se constitui da definição antecipada dos objetivos a serem perseguidos e dos meios a serem utilizados para tal, com vistas a alcançar a missão da empresa.

GLAUTIER e UNDERDOWN (1994, p. 436) definem planejamento como o processo de pensamento que precede ações e está diretamente relacionado à tomada de decisões presentes e vinculadas ao futuro. O planejamento objetiva melhorar a qualidade das decisões, levando em consideração todos os fatores relevantes, e assegurando que as alternativas de ações sejam empreendidas conforme a estratégia estabelecida.

Do ponto de vista do gerenciamento ambiental, a Norma ISO 14000, no que tange ao planejamento, recomenda que a implementação seja precedida de um processo de identificação e avaliação da interação da empresa com o meio ambiente, quanto aos impactos potenciais recíprocos, devendo observar, quanto aos aspectos ambientais da atividade da organização:

- “a) emissões atmosféricas;

- b) lançamentos em corpos d'água;

- c) gerenciamento de resíduos;

- d) contaminação do solo;

- e) uso de matérias-primas e recursos naturais; 
- f) outras questões locais relativas ao meio ambiente e à comunidade.” (ABTN, 1996, p. 8)

Na fase de avaliação, além dos quesitos acima identificados, devem ser analisados:

- “a) requisitos legais e regulamentares;

- b) identificação dos aspectos ambientais significativos;

- c) exame de todas as práticas e procedimentos de gestão ambiental existentes;

- d) avaliação das informações provenientes de investigações de incidentes anteriores." (ABTN, 1996, p. 8)

A partir deste processo, deve definir e manter procedimentos adequados para:

- identificar impactos significativos sobre o meio ambiente;

- atender aos requisitos legais e normatizações pertinentes aos aspectos ambientais de suas atividades, produtos ou serviços;

- estabelecer e revisar objetivos e metas ambientais;

- implantar programas de gestão ambiental para atingir os objetivos e metas.

O apêndice desta Norma esclarece que o processo de planejamento deve “...identificar os aspectos ambientais significativos a serem priorizados....", recomendando-se que seja considerado "...o custo e o tempo necessários para a análise e a disponibilidade de dados confiáveis...." (grifos nossos)

O estabelecimento de objetivos e metas na área ambiental, conforme diretrizes da política ambiental da empresa, pode requerer, na sua implementação e execução, o uso de tecnologias, que deve ser precedido de estudos para aferição de viabilidade, rentabilidade e da adequabilidade. No que tange à viabilidade financeira e rentabilidade, tais aferições se farão por meio dos instrumentos da gestão econômico-financeira ou, mais precisamente, da contabilidade de custos, com ênfase à parte de controle dos custos ambientais. 
Segundo a Norma, os objetivos devem ser específicos e as metas mensuráveis, sendo que ambos devem ser compatíveis com a política ambiental, inclusive no que se refere ao compromisso com o controle ambiental.

À recomendação de que as metas devem ser mensuradas, deve ser adicionado : física, financeira e economicamente, para melhor subsidiar o processo de avaliação dos resultados e desempenhos.

No apêndice à Norma, a Instituição ressalta que ao estabelecer seus objetivos e metas a organização poderá considerar “..o uso das melhores tecnologias disponíveis, quando economicamente viável, rentável e julgado apropriado.

A referência aos requisitos financeiros da organização não implica necessariamente que as organizações sejam obrigadas a utilizar metodologias de contabilidade de custos ambientais."(ABNT, 1996, p. 9) (grifos nossos)

Esta menção não é apropriada, dado que a decisão de escolher entre alternativas de tecnologias disponíveis viáveis e rentáveis requer um estudo de rentabilidade econômicofinanceira de produtos, processos e investimentos, o que, por sua vez, exige uma análise pormenorizada do efeito em cada um destes. Estes estudos são facilmente realizados pela área de gestão econômica da empresa, obviamente, no caso das empresas preocupadas com a correta gestão econômica de seus recursos, que tenham estrutura descentralizada e cujos custos sejam apurados por centros de resultados, departamentos, produtos, processos e atividades. O não aproveitamento da estrutura já existente implica a criação de sistemas de avaliação paralelos e repetitivos.

Esta referência remete, ainda, à afirmação deste próprio apêndice, onde se lê: 
“A integração das questões ambientais com o sistema de gestão global da organização pode contribuir para a efetiva implementação do sistema de gestão ambiental, bem como para sua eficiência e clareza de atribuições.”(ABNT, 1996, p. 8) (grifos nossos)

Percebe-se, nestas duas afirmações da Norma, uma clara contradição, dado que o sistema de contabilidade (ou contabilidade de custos) é parte fundamental do sistema de gestão global da organização, uma vez que tem a condição de responsável pela identificação, mensuração e informação dos recursos consumidos e produzidos pela empresa. Portanto, se o sistema de gestão econômica dispõe, ou poderá dispor, sem maiores dificuldades, das informações relativas aos recursos consumidos para a conservação e proteção do meio ambiente deverá ser integrado ao sistema de gestão ambiental.

\subsubsection{Implementação e Operação e o Planejamento Operacional e Execução}

A Norma ISO 14000 refere-se à "implementação e operação"; a gestão econômica, ao "planejamento operacional e execução".

A Norma surpracitada recomenda a definição e instituição de: estruturas apropriadas e definição de responsabilidades; treinamento e conscientização do corpo de colaboradores; comunicação; documentação do sistema de gestão ambiental; controle de documentos; controle operacional; e preparação e atendimento a emergências.

Todos estes quesitos envolvem consumo de recursos, sejam humanos, físicos, financeiros, pois não existem por si só. Definir a estrutura e responsabilidade exige o consumo de tempo por parte de um colaborador, o qual deve ser remunerado; a estrutura requer um espaço físico equipado, de acordo com as atividades a serem desenvolvidas. A responsabilidade só poderá ser cobrada em função da avaliação de resultados; a geração de resultados somente ocorrerá se recursos forem empregados; dada a escassez de recursos, o uso destes deve ser controlado e restrito a níveis proporcionais à escassez. 
A execução de todos estes procedimentos requer um planejamento operacional prévio.

O planejamento operacional constitui-se da identificação e seleção das melhores alternativas de ação que permitam a realização do planejamento estratégico e a quantificação dos recursos envolvidos, considerando um determinado período de tempo.

A fase de execução caracteriza-se, substancialmente, pela implementação do planejamento operacional, conforme as diretrizes estabelecidas; ou seja, é a transformação dos planos em ações. Neste momento, a viabilidade da situação idealizada será confrontada com a realidade do momento atual, por meio da busca dos recursos esperados do mercado, pelo valor previsto, do seu processamento com a capacitação e habilidade programada, e do repasse da produção ao mercado, que se espera ainda estar disposto a absorver tal produção pelo preço preestabelecido.

A alta administração deve nomear representante, ou representantes específicos, com funções, responsabilidades e autoridade, para:

- a) assegurar a implementação e manutenção dos requisitos do sistema de gestão ambiental estabelecidos;

- b) prover informações quanto ao desempenho da gestão ambiental para análise crítica e, quando necessário, aprimorá-lo.

A atribuição de responsabilidade implica que o gestor deve ser avaliado em algum momento, pois é inconcebível a idéia da manutenção de um gestor que não tenha capacidade e habilidades para a geração de resultados que agreguem valor ao resultado econômico da companhia, seja mediante o ingresso de novas riquezas patrimoniais, seja via redução de custos. 


\subsubsection{Verificação e Ação Corretiva e o Controle}

A gestão econômica requer a existência de controle, o qual se constitui no processo de acompanhamento da execução do planejamento operacional. A essência do controle se dá na comparação dos resultados realizados com os planejados. Deve ocorrer antes, durante e após o processo produtivo, tendo em vista a correção imediata, quando possível, de falhas na execução dos planos traçados, de forma a garantir a consecução dos resultados planejados.

Para GLAUTIER e UNDERDOWN (1995, p. 438), o controle está ligado à função de planejamento e tem o propósito de assegurar que os resultados das atividades realizadas estejam de acordo com o que foi planejado. Isto é efetuado pelo sistema de "feedback" das informações .... O controle é essencial para a realização de planos de curto e longo prazos. (tradução livre)

A Norma prevê para este tópico:

- Monitoramento e medição;

- Não-conformidade (ou inadequação à norma) e ações corretivas e preventivas;

- Registros;

- Auditoria do sistema de gestão ambiental.

O processo operacional, em cada uma de suas fases, deve sofrer monitoramento freqüente, de forma a evitar falhas, identificar as origens delas, providenciar medidas corretivas imediatas. Concomitantemente ao controle físico, deve ocorrer o controle de custos incorridos.

As atividades operacionais passíveis de impactos ambientais significativos devem ser periodicamente monitoradas e mensuradas, inclusive para identificação de eventuais passivos ambientais, cujo reconhecimento contábil deve obedecer ao regime de competência, ou seja, ser contabilizado no período em que o fato gerador ocorrer, independentemente da época de desembolso. 
Os gastos de realização destas tarefas e da obtenção das informações sobre as mesmas são os custos e investimentos ambientais incorridos em contrapartida a um passivo ambiental .

As não-conformidades devem ser tratadas e investigadas por pessoa instituída de responsabilidade e autoridade, a qual deve adotar medidas para reduzir quaisquer impactos, e para aplicar ações corretivas e preventivas adequadas à magnitude dos problemas; tais ações devem ser devidamente documentadas.

Diz a Norma que: "Ao estabelecer e manter procedimentos para investigar e corrigir nãoconformidades, é recomendado que a organização inclua os seguintes elementos básicos:

- a) identificação da causa da não-conformidade;

- b) identificação e implementação da ação corretiva necessária;

- c) implementação ou modificação dos controles necessários para evitar a repetição da não-conformidade;

- d) registro de quaisquer mudanças em procedimentos escritos resultantes da ação corretiva." (ABNT, 1996, p. 11)

O controle físico por si só não permite a identificação do resultado das operações, pois o objetivo deve ser atingido (eficiência), porém de forma eficaz (atingir os objetivos com o uso de tempo e recursos adequados); o volume de recursos consumidos física e financeiramente deve ser compatível com os benefícios gerados.

O processo de monitoramento e mensuração das etapas necessárias ao controle ambiental pode gerar informações quanto aos resultados físicos e financeiros. No que tange aos resultados físicos, estes podem ser formatados de maneira a confrontar resultados efetivos com os exigidos pela legislação, como, por exemplo, na apuração e avaliação do volume de resíduos poluentes produzidos e o permitido pela legislação pertinente. No que diz respeito 
aos resultados econômicos, podem ser confrontados recursos planejados versus consumidos.

\subsection{Auditoria Ambiental}

A auditoria, em si, compreende o exame sistemático ou vistoria de caráter técnico e especializado de processos em uma empresa. Enquanto a auditoria contábil se preocupa com a adequação das práticas e procedimentos contábeis à luz dos princípios fundamentais de contabilidade, visando à continuidade da empresa, a auditoria ambiental volta-se para as práticas e procedimentos utilizados na operacionalização do controle e conservação ambientais, comparativamente aos parâmetros estabelecidos no sistema de gerenciamento ambiental adotado pela empresa, com vistas à continuidade da empresa sem agressão ao meio ambiente.

A organização deve manter programas e procedimentos para auditorias periódicas do sistema de gestão ambiental, a fim de verificar o nível de conformidade, implementação e manutenção, além de obter informações quanto aos resultados das auditorias.

\subsection{Análise Crítica pela Administração}

O sistema de gestão ambiental deve ser analisado periodicamente pela alta administração, assegurando sua "conveniência, adequação e eficácia contínuas". Esta análise deve ser feita do ponto de vista operacional, físico, financeiro e econômico, pois o fluxo de recursos financeiros disponíveis se constitui na "mola mestra" da Organização para a tomada de decisão concernentes a investimentos e gastos, bem como o retorno econômico de cada uma das atitudes empreendidas e não empreendidas.

Reconhecidamente, muitas atividades econômicas não podem, devido ao nível geral de desenvolvimento da tecnologia, se desenvolver sem a produção de uma quantidade mínima de resíduos. Assim, os órgãos técnicos responsáveis determinam os padrões de emissão 
mínima destes resíduos. Desta forma, as empresas precisam adequar seu sistema operacional com vistas a, no mínimo, equiparar sua produção de resíduos com o que a legislação admite, e adotar um sistema de monitoramento constante para acompanhar estes resultados.

Informações como as contidas no Relatório Ambiental Anual da empresa sueca MODO sobre desempenho, com a relação do volume de cada um dos resíduos produzidos, comparativamente aos níveis permitidos pela legislação local e com a produção do período anterior, subsidiam o gestor ambiental quanto à eficácia dos procedimentos adotados, bem como aos redirecionamentos necessários.

O produto do sistema de gerenciamento ambiental deve ser de natureza técnica, física e monetária, como resultado da integração dos vários processos que estão associados ao controle, preservação e recuperação ambiental, pois somente assim poderá ser considerado um instrumento eficiente e eficaz para o processo de decisão dos gestores. 


\section{V - CONTABILIDADE POR ATIVIDADES}

Este capítulo trata da gestão estratégica de custos, enfocando a Contabilidade por Atividades como instrumento fundamental para identificação da origem dos custos indiretos de fabricação e sua correta associação com os elementos que os geraram. No tópico conclusivo - A importância do Custeio por Atividades - enfatiza-se a relevância deste sistema para a apuração dos custos das atividades, processos e funções essenciais à continuidade da empresa, mas indiretamente associados com a produção, particularmente no que tange aos procedimentos inerentes à gestão ambiental.

\section{1 - GESTÃO ESTRATÉGICA DE CUSTOS}

Os elementos básicos na condução de qualquer atividade econômica envolve recursos de natureza econômico-financeira-física e humanos. Desta forma, a administração geral deve ser segmentada com vistas a dar um tratamento mais específico à facção operacional propriamente dita e à facção econômica. Daí o surgimento da gestão econômica, da gestão de recursos humanos, da gestão ambiental etc.

Obviamente, há interdependências destas facções; a principal delas é a de que agem com um fim comum - missão da empresa. A gestão econômica, particularmente, é a de maior abrangência, pois os recursos econômico-financeiros estão presentes em todas as demais, e se constituem em um dos mais elementares aspectos que asseguram a continuidade da empresa - sem a quantidade suficiente destes recursos (econômico-financeiros), nos momentos oportunos, nenhuma outra facção sobrevive.

A gestão econômica apóia-se no sistema de contabilidade para ter a identificação, mensuração e avaliação dos recursos econômico-financeiros transitados pela empresa. A contabilidade identifica, mensura e acumula os custos de acordo com o objeto a ser custeado, utilizando-se, para tal, do subsistema de custos. 
O significativo aumento da concorrência provocou um grande processo de alavancagem da qualidade e equilíbrio dos preços dos produtos elaborados pelas empresas. Isto porque a conquista e manutenção de um espaço no mercado requerem satisfação dos clientes. Assim, de forma geral, as empresas têm melhorado a qualidade e esforçam-se no sentido de manterem seus preços em níveis compatíveis com o da concorrência, no que tange aos produtos similares.

Tecnologias de ponta foram desenvolvidas no sentido de melhorar, agilizar e dotar de qualidade a atuação das empresas. Uma das características destas novas tecnologias é a automação e informatização, característica esta que já eliminou, e tem eliminado, considerável parte do volume de mão-de-obra utilizado pelas empresas de forma geral, como também uma parcela da margem de perda de matéria-prima, em função da extinção do manuseio das mesmas.

NAKAGAWA $(1991, p .34)$ refere-se à obsolescência dos sistemas tradicionais de custeio da seguinte forma:

“As tecnologias avançadas de produção, ao mesmo tempo que vêm revolucionando os processos de produção no nível de chão de fábrica, têm provocado, simultaneamente, sensíveis alterações nos padrões de comportamento dos custos. Ao mesmo tempo em que a incidência em custos com materiais e mão-de-obra direta vem decrescendo, os custos indiretos de fabricação (CIF), como a depreciação, gastos com engenharia e processamento de dados, têm aumentado sensivelmente, ...

Esta tendência tem obscurecido a representatividade dos custos de manufatura calculados de acordo com os sistemas tradicionais de custeio, impedindo mesmo que a administração tenha uma compreensão clara da relação de causa e efeito entre os numerosos fatores que determinam o consumo de recursos (direcionadores de custos) e custo dos produtos." 
Neste contexto, há necessidade de adoção de critérios mais rigorosos para a associação dos custos aos produtos e para controle de gastos. A localização da origem e averiguação dos produtos ou serviços que os requerem propicia condições para a obtenção de maior grau de precisão, além de fornecer meios para o seu controle. Desta forma, a atribuição de custos às atividades necessárias para a elaboração dos produtos ou serviços apresenta-se como uma alternativa interessante.

Assim, uma nova abordagem para tratamento dos custos desenvolveu-se recentemente (década de 80), sendo seu enfoque o estudo da gestão de custos concomitantemente à gestão global da empresa. Esta nova metodologia de estratégia de custos recebeu a denominação de CMS (Cost Management System), ou gestão estratégica de custos, tendo por premissa elementar a divisão da empresa em atividades.

De acordo com esta nova abordagem, a Contabilidade deverá produzir informações verticais e horizontais sobre os custos de cada um de seus produtos e processos de produção, por meio do custeamento das atividades necessárias à consecução dos mesmos, no período e durante o ciclo de vida destes.

Segundo literaturas da área, alguns conceitos desta metodologia já são utilizados há décadas, porém de formas esparsas e não integradas, conforme menção de NAKAGAWA (1991, p. 80).

A gestão estratégica de custos por atividade pode ser mais facilmente equiparada à gestão global da empresa, pois a análise do encadeamento das atividades exigidas pelo processo produtivo permite uma visão globalizada do que a empresa faz, possibilitando a identificação da necessidade de melhorias, reestruturação e até de eliminação de atividades, além de propiciar informação de custos mais aproximada da realidade, dado que todos os custos são associados aos produtos, inclusive aqueles incorridos nas áreas administrativa e de vendas. 
A Gestão Estratégica de Custos designa, de acordo com MARTINS (1996, p. 315), “...a integração que deve haver entre o processo de gestão de custos e o processo de gestão da empresa como um todo. Entende-se que essa integração é necessária para que as empresas possam sobreviver num ambiente de negócios crescentemente globalizado e competitivo."

Segundo NAKAGAWA (1991, p. 36), "O CMS pretende fornecer as informações de custos necessárias para apoiar adequadamente as decisões estratégicas e operacionais, para a aquisição e utilização eficiente e eficaz de recursos produtivos, abrangendo todo o ciclo de vida do produto."

BERLINER e BRIMSON (1988, p. 10) definem o CMS como um sistema de planejamento e de controle, tendo, segundo os autores, os seguintes objetivos:

- Identificar custos de recursos consumidos na elaboração de atividades significativas;

- Determinar a eficiência e eficácia das atividades desenvolvidas;

- Identificar e avaliar novas atividades que podem melhorar o desempenho futuro da empresa;

- Acompanhar os 3 objetivos anteriores, no ambiente caracterizado por mudanças de tecnologias.(tradução livre)

A seguir, apresentam-se alguns dos princípios fundamentais da gestão estratégica de custos, mencionados por MARTINS (1996, p. 317).

“ $\checkmark$ custos relevantes devem ser apropriados, preferencialmente, diretamente aos objetos que se pretende custear;

$\checkmark$ devem ser identificadas bases de alocação que reflitam, adequadamente, as relações de causa e efeito entre os recursos consumidos e as atividades, e entre estas e os objetos que se pretende custear (no caso de apropriação integral de custos e despesas aos produtos); $\checkmark$ o custo real deve ser confrontado com o custo-meta; 
$\checkmark$ devem ser estabelecidos centros de custos com base em grupos homogêneos de atividades;

$\checkmark$ a utilização do Custeio Baseado em Atividades deverá melhorar o processo de apropriação (se adotada a idéia de alocação global de custos e despesas).”

MARTINS (1996, p. 318) afirma que a adoção destes princípios básicos faz com que a Contabilidade de Custos se insira em uma posição mais ampla e relevante, adquirindo maior visão estratégica e responsabilidades.

O referido autor argumenta que o contador de custos “...precisa conhecer e acompanhar todas as atividades; analisá-las quanto à sua utilidade e valor; acompanhar as efetivas conseqüências das novas tecnologias feitas ou dos novos investimentos realizados, além de verificar o desempenho de novos produtos e outras tarefas mais tradicionais.

Ele precisa conhecer quais são os planos estratégicos da empresa para participar do processo de acompanhamento e verificar se os fatos estão realmente fazendo com que a empresa se encaminhe para os objetivos previamente definidos.

Passa a ser papel também da Contabilidade de Custos prevenir, evitar, reduzir, eliminar ou otimizar os custos e as despesas, propiciando aos gestores uma postura muito mais proativa do que reativa."

\subsection{Custeio Baseado em Atividades ou Contabilidade por Atividades}

A continuidade da empresa não depende apenas de seu resultado em um dado período, mas daqueles obtidos ao longo de sua existência. A análise detalhada do comportamento passado subsidia o processo de planejamento e controle, no sentido de corrigir falhas e introduzir melhorias, desde que baseado nas verdadeiras causas que provocam os custos. 
Para atingir a missão a que se propõe, a empresa desenvolve uma estrutura organizacional, devidamente hierarquizada, onde cada uma das partes é responsabilizada pelo desempenho de uma função, a qual necessita de um encadeamento e de uma sequiência lógica e objetiva de atividades. Estas serão realizadas por meio de um conjunto de tarefas que, por sua vez, requerem a conjugação de uma série de operações.

Como instrumento da gestão estratégica de custos, a Contabilidade por Atividades ou Custeio Baseado em Atividades ou ABC (Activity Based Costing) tem por objetivo básico tratar os custos indiretos de fabricação. Os custos diretos deverão receber o mesmo tratamento, visando à uniformidade de procedimentos de custeio.

Este sistema de custeio acumula os custos por atividades, sob a premissa de que são estas que absorvem os recursos físicos e financeiros das empresas, enquanto que os produtos e serviços demandam atividades na sua elaboração e execução.

Desta forma, se faz necessário pesquisar e entender como os custos são incorridos, quais atividades os justificam e a freqüência e qualidade com que estas atividades se repetem.

O desempenho das funções, processos e atividades deve ser constantemente avaliado com a finalidade de assegurar o cumprimento dos objetivos maiores da empresa.

Assim sendo, são definidos como elementos importantes desta abordagem da Contabilidade:

- Função: grupo de processos desempenhados com uma finalidade específica, como a função de marketing e venda e a de controle ambiental, por exemplo;

- Processo: conjunto de atividades encadeadas com um fim específico, como, por exemplo, uma linha de montagem de um produto ou o conjunto de procedimentos necessários para o tratamento de uma determinada quantidade de resíduos poluentes, em um período em particular; 
- Atividades: ações empreendidas e recursos consumidos para se chegar a um dado objetivo;

- Tarefa: trabalho desenvolvido para a execução das atividades; e

- Operação: operacionalização das tarefas, ou seja, a menor fração de trabalho.

No que tange aos processos, embora atividades semelhantes sejam desenvolvidas por distintos centros de custos, ou até por distintas empresas, a seqüência e composição (tarefas e operações) destas podem ser diferentes, seja por definição da administração, seja por diferenciação dos insumos utilizados, ou das características do produto final.

A identificação dos processos, a forma como é conduzido e informações quanto ao seu desempenho operacional e financeiro permitem uma visualização da integração das atividades e, principalmente, entre os centros de custos, fato este que facilita e dinamiza a identificação de pontos falhos, propiciando, com isso, condições de melhoria e reestruturação mais ágeis.

As atividades de uma empresa devem ser identificadas no período inicial da implementação da contabilidade por atividades. Deste processo resultará uma lista de atividades ou um plano de atividades, parafraseando o conhecido plano de contas contábil.

A descrição de todas as atividades deve estar vinculada aos objetivos que as exigem, em forma seqüencial, e quantificada conforme a necessidade de repetições demandadas, como, por exemplo, as atividades pertinentes ao objetivo de pesquisa e desenvolvimento de produtos, as relativas à execução do processo operacional e aquelas destinadas ao apoio deste.

No processo de identificação das atividades, algumas peculiaridades, quanto a sua freqüência (repetitivas e não repetitivas) e nível de ligação com o produto final (primárias ou secundárias), podem ser destacadas. Há, ainda, aquelas que adicionam valor e as que não adicionam valor. Estas últimas devem merecer um processo especial de investigação 
sobre sua essencialidade, pois podem ser decorrentes de desperdícios e perdas, devendo, portanto, ser eliminadas ou reduzidas ao mínimo possível.

BRIMSON (1996, p. 64) sintetiza os elementos do custeio por atividades, com o seguinte exemplo:

\begin{tabular}{|ll|}
\hline Função & Marketing e Vendas \\
Processo & Venda de produtos \\
Atividade & Proposta de um negócio \\
Tarefa & Preparar proposta \\
Operação & Datilografar a proposta \\
Elemento e informação: & Cliente \\
& Peça \\
& $\ldots .$. \\
& $\cdots$ \\
& Data de entrega \\
\hline
\end{tabular}

De forma geral, o termo "atividades" traz implícitas as tarefas e operações. A necessidade do detalhamento para fins de custeio deve ser definida de acordo com a relevância das peculiaridades de cada processo e do volume inerente destas tarefas ou operações, bem como pela necessidade de um maior grau de precisão na apuração dos custos.

É óbvio que a complexidade desta mensuração e análise dependerá do tipo de produto ou serviço prestado e da relevância dos custos envolvidos. Vale ressaltar que a mensuração e informação dos custos no nível das operações ou tarefas pode representar certo preciosismo e consumo de tempo elevado e desnecessário, enquanto que a informação por funções pode omitir aspectos importantes quanto à eficiência e eficácia dos processos e atividades.

\subsubsection{Centros de Custos}


A implantação do sistema de contabilidade por atividades requer a prévia estruturação das unidades de trabalho da empresa, via centros de custos, de forma a subsidiar o processo de avaliação de desempenho, de resultados, bem como gerenciar detalhadamente o processo operacional. Tais "centros" devem congregar apenas atividades semelhantes.

As funções e suas ramificações podem ser inerentes a um único centro de custos, ou então ser desenvolvidas pela integração de vários destes, pois, em alguns "centros", são executadas apenas uma atividade, em outros, apenas uma parte destas (tarefas/operações) e, ainda, em outros são realizadas várias atividades que podem representar a função completa. Portanto, a Contabilidade colhe dados sobre as atividades entre os diversos centros de custos ou, em cada um deles, obterá dados sobre diversas atividades ali desenvolvidas, ou, ainda, somente sobre tarefas ou operações, se estas forem distribuídas entre vários centros de custos. Os custos podem ser sumariados por atividades, processos, função, produtos, centros de custos e por ciclo de vida dos produtos.

É possível o aproveitamento da estrutura de centros de custos, já estabelecida pelos sistemas tradicionais, tendo em vista que o elemento essencial do próprio CMS são as atividades.

\subsubsection{Custos das Atividades}

O custeamento das atividades exige o estabelecimento de parâmetros (financeiros e físicos) para a mensuração do seu desempenho.

MARTINS (1996, p. 317-318) descreve alguns princípios de mensuração de desempenho que precisam ser observados:

" $\checkmark$ devem ser estabelecidas mensurações de desempenho para as atividades relevantes;

$\checkmark$ essas mensurações de desempenho devem ser de natureza financeira e não-financeira (produtividade por hora trabalhada, por quilo consumido, vendas por funcionário, dias de 
atraso dos balancetes contábeis, grau de satisfação dos adquirentes dos serviços do departamento jurídico etc.);

$\checkmark$ as mensurações de desempenho devem ser consistentes com os objetivos da empresa;

$\checkmark$ as mensurações de desempenho devem melhorar a visibilidade dos direcionadores de custos, quando utilizados."

\subsubsection{Direcionador de Custos}

As atividades receberão a parcela de custos equivalente ao consumo de recursos. Para tanto, necessário se faz estabelecer uma relação causal entre custos e atividades relacionados, ou seja, um direcionador de custos; uma causa que os provoque. Por exemplo, o custo de salários a ser atribuído a uma atividade é decorrente da utilização de certa quantidade de horas de trabalho de um empregado, ou de uma máquina, assim como o custo de aluguel, atribuído à atividade, é conseqüência de esta ocupar um espaço físico (área ocupada) durante sua realização.

Direcionador de custo é, portanto, o elemento que causa ou justifica a atividade e, por conseguinte, seus custos, constituindo-se no parâmetro para mensuração de desempenho das atividades.

SHANK e GOVINDARAJAN (1997, p. 21-22) fazem a seguinte assertiva: "No gerenciamento estratégico de custos sabe-se que o custo é causado, ou direcionado, por muitos fatores que se inter-relacionam de formas complexas. Compreender o comportamento dos custos significa compreender a complexa interação do conjunto de direcionadores de custo em ação em uma determinada situação...."

BRIMSON (1996, p. 153) apresenta o seguinte quadro exemplificativo dos direcionadores de custos:

\begin{tabular}{|ll}
\hline Fator de producão & Medida \\
Pessoal & Tempo
\end{tabular}




\begin{tabular}{|ll|}
\hline Tecnologia & Horas de máquina/tecnologia \\
Instalações & Área \\
Utilidades & Quilowatt/hora \\
\hline
\end{tabular}

Segundo ROBLES (1992, p. 163), "Os direcionadores constituem um método de alocação de custos. Os direcionadores medem a freqüência ou a intensidade da demanda de certo tipo de atividade."

As atividades consomem recursos, sendo que o custo destes é determinado a partir do direcionador de custos. Os produtos consomem atividades; portanto, seus custos serão definidos de conformidade com as características e repetições do direcionador de atividades. Tem-se, pois, o direcionador de custos e o de atividades.

MARTINS (1996, p. 103 e 104) aborda estes dois tipos de direcionadores:

- direcionador de custos (que este autor denomina como direcionador de recursos): "identifica a maneira como as atividades consomem recursos e serve para custear as atividades."

- direcionador de atividades: "...identifica a maneira como os produtos "consomem" atividades e serve para custear produtos (ou outros custeamentos), ou seja, indica a relação entre as atividades e os produtos. Por exemplo, o número de inspeções feitas nas diferentes linhas de produto define a proporção em que a atividade Inspecionar Produção foi consumida pelos produtos."

O autor (1996, p. 104) observa que um direcionador pode servir à definição de custos de uma ou mais atividades; contudo, uma atividade deverá ter um único direcionador de custos. Por exemplo, a quantidade de horas de trabalho de funcionários pode ser a causa (direcionador de custos) de diferentes atividades. Porém, o custo de uma atividade será causado pela quantidade de horas-homem ou pela quantidade de horas-máquina, não pelos dois concomitantemente. Uma atividade de "corte" pode ser feita manualmente, ou por 
máquinas. A forma como as atividades são desenvolvidas é que determina o direcionador de custos.

O referido autor (1996, p. 104) aborda esta questão com a seguinte assertiva:

"Cada atividade deve ter apenas um direcionador, porém um direcionador pode servir a mais de uma atividade. O processo de identificação é buscar, para cada atividade, resposta à seguinte pergunta: "o que é que determina ou influencia o uso desta atividade pelos produtos? ou "como é que os produtos se utilizam desta atividade?"

O processo de verificação, identificação e quantificação dos direcionadores de custo é denominado rastreamento.

BRIMSON (1996, p. 171) afirma que "O processo de identificar atividades específicas e determinar quanto de cada atividade é consumido pelo objetivo final do custo é conhecido como rastreamento. Rastrear o custo até o usuário final tem dois objetivos básicos: entender a estrutura de custos atual e determinar se atividades alternativas podem ser melhores."

\subsubsection{Atribuição de Custos às Atividades}

A atribuição de custos às atividades deve ser feita de forma direta, por rastreamento e, por último, se inevitável, por rateio. (MARTINS, 1996, p. 102)

De forma direta, quando puderem ser objetivamente associados à realização da atividade, como nos casos de consumo de matéria-prima ou outros insumos básicos.

Serão atribuídos com base em rastreamento quando não for viável sua associação direta, mas possível uma identificação da relação de causa e efeito entre o custo e a atividade, tais como: quantidade de horas-homem trabalhada ou área ocupada. 
O rateio será utilizado, em última instância, quando não for possível estabelecer, com razoável grau de precisão, o direcionador de custos. Neste caso, utiliza-se um parâmetro que possa representar uma distribuição razoável dos custos indiretos entre as atividades. Devido ao subjetivismo inerente ao estabelecimento de tal parâmetro, muitas vezes se incorre em arbitrariedades.

O rastreamento tem uma base fundamentada, mediante pesquisas e estudos de causa e efeito, enquanto que o rateio, embora guarde algum tipo de relação com o departamento ou atividade, é determinado em base arbitrária e, algumas vezes, subjetiva.(MARTINS, 1996, p. 106)

A divisão da empresa em atividades, o rastreamento destas, a identificação de seus direcionadores de custos geram condições para se entender como e quando os custos são incorridos.

Observa-se que o elemento crucial no sistema de contabilidade por atividades é o direcionador de custos, pois são eles que determinam a acurácia dos custos atribuídos às atividades e, por conseguinte, aos produtos.

Os direcionadores, bem como a quantidade destes, dependem do nível de detalhamento dos custos que se pretenda e da precisão quanto aos dados obtidos.

\subsubsection{Custos Pertinentes às Atividades}

As atividades podem estar automatizadas ou serem manuais. Elas acontecem em todas as empresas, independentemente do porte, localização, forma de administração da empresa, nível de especialização das pessoas que as realizam, ou tipos de máquinas e equipamentos que a operam. Contudo, via de regra, são diferentes de uma organização para outra. Daí a necessidade do processo de identificação das atividades ocorridas internamente, 
observando-se as características próprias de cada empresa, ou seja, não há um padrão que possa ser aplicado universalmente, ou mesmo entre empresas do mesmo segmento econômico.

O sistema de contabilidade por atividades somente se justifica se um volume razoável dos custos, inclusive as despesas, incorridos na empresa (diretos e indiretos) puder ser rastreado e atribuído às atividades

\subsubsection{Custos das Áreas Administrativas}

O custeamento dos produtos não deve se restringir à alocação dos custos provenientes da área de produção. Deve incluir, também, os custos das áreas administrativas e de vendas e demais envolvidas.

O sistema de contabilidade por atividades propicia condições para alocação destes custos, uma vez que está calcado no custeamento das atividades, e estas oferecem um maior grau de associação com os produtos desenvolvidos.

Desta forma, todas as atividades desenvolvidas dentro da empresa, sem exceção, devem ser identificadas, analisadas e custeadas, desde aquelas especificamente relacionadas ao processo de fabricação, até as atividades de apoio, onde também se incluem as executadas na área administrativa.

Alguns custos, por suas características de origem, não podem ser alocados com base em atividades, como o aluguel ou o imposto territorial urbano. Nestes casos, a alocação por área ocupada pelos centros de custos é a melhor alternativa. A energia elétrica terá seu custo alocado de acordo com as características físicas da empresa; por exemplo, empresas que tenham medidores de consumo por máquina poderão alocar às atividades o custo equivalente ao consumo de quilowatts necessários à sua execução, ou por hora de atividade. No caso de medidores centrais ou da energia geral consumida pela empresa, 
torna-se impossível fazer uma associação precisa quanto às parcelas atribuíveis a cada atividade; portanto, neste caso, o rateio mostrar-se a única alternativa possível.

\subsubsection{Amortização de Custos de Itens do Ativo Permanente}

A amortização dos investimentos em ativos imobilizados é uma questão importante e que deve merecer atenção especial. Uma delas é concernente ao valor de registro dos ativos. Pelas premissas contábeis, tais ativos devem estar registrados pelo custo histórico de aquisição; contudo, com o passar tempo, estes podem ficar defasados em função de perda do poder aquisitivo da moeda ou por obsolescência.

Desta forma, para melhorar a qualidade da informação prestada, o custo corrente de mercado se mostra como a melhor alternativa para refletir uma informação de custos em bases atuais.

Além do ajuste ao valor de mercado, BERLINER e BRIMSON (1988, p. 115) ainda sugerem que a estes ativos seja adicionado o custo de oportunidade do investimento, o qual estaria representando o custo do capital empregado na aquisição do ativo, independentemente de este ser próprio ou de terceiros.

Quanto ao método de depreciação, deve ser aquele que melhor reflita as variações das contribuições dos ativos, ao longo da vida útil destes, como, por exemplo, o método das unidades produzidas ou o método de horas-máquina.

\subsection{Ciclo de Vida}

O Ciclo de Vida de um produto inicia-se no projeto de sua concepção, compreendendo todas as etapas necessárias ao estudo e desenvolvimento do projeto básico, todos os 
preparativos para implementar a produção, todos os processos operacionais em si realizados durante o período de sua manutenção em linha, todos os períodos de estocagem, e finaliza na última distribuição, a qual precede a sua desativação. Isto significa que muitos produtos têm o seu ciclo de vida encerrado, após longos anos de permanência em linha.

BRIMSON (1996, p. 115) ressalta a importância da apuração dos custos do produto por ciclo de vida:

“...A contabilidade por ciclo de vida fornece uma estrutura para desenvolver e reportar o custo e desempenho de ativos importantes durante toda a vida útil. O ciclo de vida começa com a identificação inicial das necessidades do consumidor e estende-se pelo planejamento, pesquisa, projeto, desenvolvimento, produção, avaliação, utilização, apoio logístico em operação, obsolescência e baixa. O custo destas atividades do ciclo de vida representa no total o custo do ciclo de vida do produto. Os ativos para os quais os custos do ciclo de vida são normalmente computados incluem produtos, processos, projetos e sistema."

Em termos tradicionais, normalmente os gastos de pesquisa e desenvolvimento, cujos resultados dependem das incertezas que permeiam o futuro, são contabilizados como despesas do período em que são incorridos. Sob a ótica da Contabilidade por Atividades, estes custos não só devem ser diferidos para futura contraposição com as receitas geradas pelo produto desenvolvido, mas, também, acumulados para cômputo do custo do ciclo de vida. Além disso, sob esta nova abordagem, os gastos relacionados com propaganda, publicidade e distribuição do produto são associados com as atividades executadas para tal e computadas para apuração dos custos do ciclo de vida.

Com esta postura, os custos dos produtos estarão completos, uma vez que computarão todos os gastos incorridos desde antes do início da efetiva produção e que, sem os quais, tal produção não poderia ser viabilizada até a entrega aos clientes, além de proporcionar 
condições para mensuração do nível de sucesso (ou fracasso) na sua implementação e manutenção.

SHANK e GOVINDARAJAN (1997, p. 231) destacam que:

“...Na maioria das empresas de hoje, grande parte dos custos do produto estrategicamente relevantes ocorre muito antes que o produto atinja o estágio de fabricação (isto é, custos de pesquisa e desenvolvimento) e/ou muito tempo depois que ele deixa a fábrica (isto é, custos de marketing e distribuição). Qualquer que seja o sistema de registros contábeis usado, os custos incorridos em projeto, desenvolvimento, venda, distribuição e serviço ao cliente são componentes muito relevantes do custo do produto para análise estratégica."

O avanço da tecnologia tem contribuído para reduzir significativamente o ciclo de vida dos produtos. A cada dia uma nova linha de produtos surge no mercado e, com freqüência, com as características de descartáveis e de portáteis. A Contabilidade por Atividades traz a grande vantagem de associar a redução dos custos às atividades eliminadas em função da redução do ciclo de vida. Se isto ocorrer, naturalmente as atividades serão reduzidas e, portanto, seus custos.

BRIMSON (1996, p. 201) entende que:

“...Ciclos de vida mais curtos aumentam a necessidade de se conhecer o custo total do produto durante todo seu ciclo de vida, para determinar sua lucratividade. Ciclos de vida mais curtos significam que as empresas têm menos tempo disponível para reagir às mudanças na demanda do mercado e recuperar os custos de desenvolvimento dos produtos e processos."

A Contabilidade por Atividades, tratando do custeamento do custo do ciclo de vida dos produtos, ou mesmo dos processos, encara tais custos como investimentos necessários à realização destes ciclos. E em obediência ao regime de competência, ditado pelas 
premissas contábeis mais elementares, os custos deveriam ser confrontados com os benefícios gerados.

O processo de trabalho somente gera benefícios efetivos depois de ter sido concluído. Assim, o benefício integral do produto desenvolvido e comercializado pela empresa somente pode ser mensurado quando do encerramento do seu ciclo de vida, além de permitir uma melhor confrontação entre os períodos de tempo.

BRIMSON (1996, p. 145) apresenta o seguinte exemplo de apuração dos custos de um ciclo de vida:

\begin{tabular}{|l|r|r|r|r|r|}
\hline $\begin{array}{c}\text { Anos de } \\
\text { Vida do } \\
\text { Ativo }\end{array}$ & $\begin{array}{c}\text { Reforma } \\
\text { das } \\
\text { Instalações }\end{array}$ & $\begin{array}{c}\text { Engenharia } \\
\text { Industrial }\end{array}$ & $\begin{array}{c}\text { Programação } \\
\text { de Equipto. } \\
\text { de Controle } \\
\text { Numérico }\end{array}$ & $\begin{array}{r}\text { Engenharia } \\
\text { de Produto }\end{array}$ & $\begin{array}{c}\text { Total de } \\
\text { Custos Não } \\
\text { Recorrentes }\end{array}$ \\
\hline 1 & $\$$ & $\$$ & $\$$ & $\$$ & \multicolumn{1}{|c|}{$\$$} \\
2 & 40.000 & 25.000 & 15.000 & 40.000 & 120.000 \\
3 & & & 20.000 & 50.000 & 70.000 \\
4 & & & 25.000 & 40.000 & 65.000 \\
5 & & & 10.000 & 20.000 & 30.000 \\
Totais & 40.000 & 25.000 & 75,000 & 150.000 & 290.000 \\
\hline
\end{tabular}

Assim, mesmo que a atividade seja realizada no período corrente, seus custos (diretos ou indiretos, variáveis ou fixos) devem ser alocados aos produtos beneficiados no momento em que estes forem vendidos. Estes custos serão acumulados ao longo do ciclo de vida do produto, preferencialmente acumulados por atividades, de forma a facilitar qualquer elaboração de informações que se façam necessárias, como custos de determinadas 
atividades, isoladamente, ou de um processo em particular ou de cada um destes em um determinado período de tempo etc.

Os processos de produção por encomenda, em casos específicos, podem apresentar coincidência entre custos do período e das atividades, processos e ciclo de vida, pois, dependendo das características do produto, o processo de elaboração pode ser consumado dentro do próprio exercício social. Neste caso, tanto o custo das atividades primárias como das secundárias serão alocados no mesmo período.

NAKAGAWA $(1991, p$. 84) ressalta a importância gerencial do custo do ciclo de vida:

"Embora os custos do ciclo de vida não possam ser reportados para efeitos da contabilidade financeira, devem ser coletados e acumulados para atender aos objetivos da gestão estratégica de custos. Esta acumulação, geralmente, ultrapassa o período contábil de um ano e deve ser feita por produto, função, atividade e elementos de custos. Os custos e despesas relativos ao período contábil, tais como desenvolvimento de produtos, marketing e distribuição física, devem ser apropriados diretamente ao produto ou, se alocados, devem sê-lo por meio de uma base adequada."

Os custos do ciclo de vida podem ser úteis para a projeção e avaliação da lucratividade dos produtos no longo prazo; da eficácia do planejamento do ciclo de vida; dos custos das alternativas escolhidas na concepção do produto; e dos custos das tecnologias utilizadas em cada produto.

MARTINS (1996, p. 304) salienta que a informação quanto ao custo do ciclo de vida e ao desempenho do produto permite uma visão horizontal sobre esse desempenho durante sua manutenção, proporcionando condições para avaliação dos investimentos realizados no mesmo, comparativamente aos benefícios econômicos obtidos, seja por meio de sua colocação no mercado, seja mediante a produção de outros ativos, além da visão vertical, que evidencia o resultado auferido em cada período. 
Isto é particularmente importante na questão dos custos ambientais, dado que as atividades inerentes ao controle ambiental se dispersam entre os vários departamentos que compõem a empresa, fazendo da análise dos fluxos de custos uma ferramenta fundamental para a verificação do desempenho da empresa.

Uma questão elementar, no cômputo do custo dos processos, ou do ciclo de vida dos produtos, é o poder aquisitivo da moeda. A informação somente será útil se computar, ao longo do desenvolvimento, seja do processo, seja do ciclo de vida, os custos das atividades em moeda de mesmo poder aquisitivo. Caso contrário, em conjunturas inflacionárias, os custos apurados estarão deturpados por serem produto do somatório de moedas diferentes, em termos de poder aquisitivo.

\subsection{Apuração dos Custos}

\subsubsection{Do total das Atividades}

A apuração dos custos do total das atividades é feita pelo somatório dos custos dos recursos consumidos, como matéria-prima, valor correspondente à quantidade de horashomem trabalhadas. Estes recursos podem ser adquiridos externa, como também internamente, em decorrência do resultado de atividades já concluídas.

MARTINS (1996, p. 101) afirma que "o custo de uma atividade compreende todos os sacrifícios de recursos necessários para desempenhá-la. Deve incluir salários com os respectivos encargos sociais, materiais, depreciação, energia, uso de instalações etc."

BRIMSON (1996, p. 129) tratando de custos-padrão, entende que "custo de uma atividade é o custo de todos os fatores rastreáveis de produção dividido pelo volume planejado da atividade. Um custo-padrão (planejado) de uma atividade é o somatório dos custos dos fatores rastreáveis de produção para um volume planejado de atividade. Assim, o custopadrão de uma atividade depende de uma previsão da quantidade de suas ocorrências.” 
E complementa afirmando que "a primeira etapa na determinação do custo de uma atividade é definir o modelo de custo. Um sistema de contabilidade por atividade pode utilizar uma variedade de modelos de custos, tais como real, padrão, orçado, planejado ou de engenharia...."

\subsubsection{Do Processo}

O custo do processo é o somatório dos custos das atividades inter-relacionadas para a consecução dos objetivos de uma função, como as atividades inerentes ao processo de venda que concretizam os objetivos da função de marketing e vendas.

\subsubsection{Do Direcionador de Custos de uma Atividade Específica}

O custo total das atividades, dividido pela quantidade de ocorrências do direcionador de custos, em um centro de custos, é igual ao custo unitário do direcionador.

\subsubsection{Da Atividade Inerente à Produção de um Determinado Produto}

O custo unitário do direcionador será multiplicado pela quantidade de vezes que o direcionador se repete para a execução da atividade consumida pelo produto; desta forma, tem-se o custo das atividades realizadas para a elaboração de um determinado produto.

\subsubsection{Do Produto}

O custo unitário do produto será definido a partir da divisão do custo da atividade, atribuído ao produto, pela quantidade produzida.

\subsubsection{Do Centro de Custos}


O custo unitário do direcionador será multiplicado pela quantidade de vezes que o direcionador se repete para a execução da atividade, dentro de um centro de custos específico, obtendo-se, assim, o custo da atividade realizada no mesmo. O resultado do centro de custos será obtido mediante o somatório do custo de todas as atividades ali desenvolvidas.

\subsubsection{Do Ciclo de Vida}

O custo de todo o ciclo de vida de um produto é obtido via somatório de todos os custos atribuídos a estes, desde o período de sua concepção até o momento em que sua produção foi desativada, ou seja, são os custos acumulados, ao longo do tempo, por meio dos produtos, das funções, das atividades e elementos de custos, incluindo-se gastos com o desenvolvimento, marketing e custos de distribuição, de forma a assegurar a apuração dos custos totais e avaliar, com maior precisão, as decisões de preço e da lucratividade obtida.

\section{2 - IMPORTÂNCIA DO CUSTEIO POR ATIVIDADES}

Administrar custos requer o conhecimento de onde e por que eles ocorrem, sua freqüência e, conseqüentemente, seu papel no produto final da companhia. Algumas vezes, pode-se encontrar, em uma empresa, atividades e, portanto, custos que não se justificam, seja pelo valor, seja pela utilidade para o atingimento da missão para a qual as companhias existem. O rateio de custos indiretos, de forma arbitrária, não proporciona esta visão da importância da atividade.

O custeio por atividades conduz a um valor mais preciso dos custos incorridos, dado que reduz sensivelmente todas as formas de rateio utilizadas pelos sistemas tradicionais.

Assim sendo, passa-se a ter informações mais confiáveis sobre os recursos realmente consumidos em cada processo, função, por produto e durante todo o ciclo de vida destes. 
Em decorrência, fica mais evidente a existência de desperdícios, a origem e causa destes e das fases do processo operacional passíveis de melhorias.

A estruturação da empresa por atividades e a determinação dos custos com maior grau de exatidão permite entrever, e analisar com mais propriedade, as alternativas de terceirização de atividades, processos e funções.

A apuração e análise dos custos por processos e funções é de extrema importância na gestão econômica da empresa como um todo, principalmente porque existe uma série destes que são essenciais à continuidade da companhia, porém não estão diretamente associados aos produtos fabricados. É, por exemplo, o caso das atividades, processos e funções destinados ao gerenciamento ambiental. Além de sua essencialidade, da grande atenção do público externo sobre seu desempenho, esta área destaca-se ainda pelo grande volume de recursos consumidos.

Assim, os resultados da área de gestão ambiental devem ser rigorosamente mensurados e avaliados econômica, financeira e fisicamente de forma a garantir um adequado balanceamento de recursos possuídos pela companhia, para assegurar a eficácia da aplicação destes recursos e para satisfazer as exigências do público externo, ou, mais precisamente, para o cumprimento da responsabilidade social da empresa.

Ressalte-se que estes são os fatores fundamentais da utilidade do sistema de custeio por atividades. O uso dos sistemas tradicionais e, por conseguinte, os rateios dos custos indiretos de fabricação, não possibilita à empresa visualizar com precisão o total dos custos ambientais, quais atividades, processos e funções os requerem, e a eficácia dos recursos consumidos.

O sistema de custeio por atividades permite, ainda, uma visualização completa do relacionamento das unidades de trabalhos (departamentos, centros de custos, de resultados ou de investimentos). Isto possibilita melhorar e agilizar a integração das áreas, a 
identificação dos usuários de cada uma delas, avaliando, conseqüentemente, suas necessidades para melhor atendê-las, podendo, inclusive, subsidiar o aperfeiçoamento do planejamento estratégico e operacional.

Logo, o sistema $\mathrm{ABC}$ é o único que se adequa a esta área de conhecimento, pormenorizando os custos ambientais, no sentido de subsidiar a estratégia de custos da empresa e do cumprimento de sua responsabilidade social.

A mensuração dos custos dos produtos durante o seu ciclo de vida, por meio deste sistema de custeio, propicia, ainda, condições para identificar produtos cuja vida útil possa ser aumentada/reduzida, que possam ser aperfeiçoados e utilizados como modelo para a colocação de novas linhas de produto e que justifiquem investimentos e/ou demonstrem lucratividade.

As vantagens do gerenciamento por atividade são descritas por BRIMSON (1996, p. 74):

- "Estabelecer metas de custo e desempenho mais realistas, derivadas do planejamento estratégico;

- Identificar desperdícios e fatores que direcionam o custo;

- Melhorar a qualidade das decisões na determinação de preços, fabricar/comprar e estimativas pelo conhecimento de um custo de produto correto (que é derivado do rastreamento do custo das atividades aos produtos)."

Segundo MARTINS (1996, p. 313), "Uma das grandes vantagens do ABC frente a outros sistemas de custos mais "tradicionais" é que ele permite uma análise que não se restringe ao custo do produto, sua lucratividade ou não, sua continuidade ou não etc., mas permite que os processos que ocorrem dentro da empresa também sejam custeados. Aliás, talvez aqui estejam seus maiores méritos." 
MARTINS (1996, p. 314) aborda, igualmente, as críticas feitas ao sistema ABC da seguinte forma:

“...a grande crítica ao uso do $\mathrm{ABC}$ está no problema do rateio dos custos fixos. ... Na verdade, o uso do $\mathrm{ABC}$ é extraordinário em termos de identificar o custo das atividades e dos processos e de permitir uma visão muito mais adequada para a análise da relação custo/benefício de cada uma dessas atividades e desses processos. Permite o levantamento do quanto se gasta em determinadas atividades, tarefas e processos onde não se agrega valor ao produto (manufaturado, na forma de serviços etc.), mesmo que com a devida cautela em função da sempre permanente presença de algum nível de erro e mesmo de arbitrariedade nesses rateios." 


\section{VI - SUGESTÕES PARA TRATAMENTO DOS GASTOS DE NATUREZA AMBIENTAL}

Este capítulo objetiva demonstrar que a Contabilidade por Atividades é a forma de custeio mais adequada, e provavelmente a única, até o momento, para identificar e mensurar os custos de natureza ambiental, bem como para demonstrar o arsenal de informações que pode estar disponível para um melhor conhecimento dos resultados econômico-financeiros apresentados pelo sistema de gerenciamento ambiental da empresa.

\section{1 - CUSTOS AMBIENTAIS}

Quando se pensa em gestão estratégica das empresas, um dos elementos essenciais é o custo. E, por assim ser, todos os custos de natureza relevante, em cada empresa, devem ser alvo de profunda atenção, estudo e análise, visando uma melhor performance do negócio como um todo e sua continuidade.

A mensuração dos custos ambientais tem esbarrado nas limitações dos instrumentos da contabilidade, já que, pela sua natureza, a maioria destes custos se enquadra na classificação de Custos Indiretos de Fabricação, ou o consumo dos recursos ocorre concomitantemente ao processo produtivo normal, dificultando, com isso, sua identificação. Pela metodologia tradicional do custeio por absorção, os custos indiretos de fabricação são rateados aos produtos, normalmente de acordo com o consumo de custos diretos. Logo, com este mecanismo, qualquer tentativa de apuração dos custos ambientais se torna vã, ou muito distante da realidade.

A Contabilidade por Atividades é uma forma inovadora de custeio, tendo surgido mais ou menos na mesma época em que a problemática ambiental inseriu-se, de forma compulsória, nas empresas. 
A apuração e avaliação dos recursos econômico-financeiros consumidos na gestão ambiental encontram respaldos mais adequados no sistema de custeio por atividades. Os gastos de natureza ambiental, na sua maioria, podem ser identificados diretamente na sua fonte de origem e com maior grau de precisão.

Embora ainda não represente a solução plena para todos os problemas de gerenciamento dos recursos consumidos na proteção do meio ambiente, mostra-se como subsídio eficiente para a gestão econômico-ambiental.

A Contabilidade por Atividades, enquanto sistema de custeio, apresenta-se como um instrumento mais apropriado para apurar os custos ambientais, dado que o objeto de custo são as atividades relevantes, desenvolvidas com fins específicos.

Como se tem demonstrado, as atividades de controle, preservação e recuperação ambiental têm adquirido crescente relevância no plano mundial e, conseqüentemente, no ambiente interno das empresas, tanto no que tange ao cumprimento da responsabilidade social destas como na gestão dos recursos econômico-financeiros que lhes são vitais. Tais atividades têm como objetivo a postura ambiental da organização e podem ser desenvolvidas em múltiplas áreas da empresa e, por conseguinte, seus custos não podem ser associados, de forma precisa, a um produto, processo ou função específicos.

Neste contexto, surge a Contabilidade por Atividades como mecanismo capaz de identificar, de forma mais aproximada, os custos inerentes às atividades ambientais e, portanto, aos agentes que os provocam. Assim sendo, permite que os resultados sejam analisados com mais propriedade, dada a evidenciação da verdadeira relação de causa e efeito dos custos.

A continuidade dos estudos sobre as variáveis que envolvem as atividades necessárias à proteção do meio ambiente, e o seu aperfeiçoamento, associada ao sistema de custeio por atividades, poderá conduzir à otimização dos resultados operacionais da empresa e do seu 
sistema de gestão estratégica de custos, principalmente daqueles inerentes à proteção ambiental.

Vale destacar que um dos princípios da gestão estratégica de custos (o CMS) é o de “...mensurar o custo dos recursos consumidos pelas atividades relevantes da empresa. Seus relatórios devem ser suficientes para satisfazer às exigências internas e externas, tais como tomada de decisões estratégicas, planejamento e controle de operações rotineiras, e demonstração de resultados econômico-financeiros da organização." (NAKAGAWA, 1991, p. 52)

As atividades de controle, preservação e recuperação ambiental são relevantes por uma razão elementar: têm influência fundamental na continuidade da empresa, em decorrência do significativo efeito que têm sobre o resultado e situação econômico-financeira, cujos impactos podem culminar na exclusão destas do mercado, em função:

- da perda de clientes, para os concorrentes que ofereçam produtos e processos ambientalmente saudáveis;

- da perda de investidores potenciais, que estejam preocupados com a questão ambiental global e com a garantia de retorno de seus investimentos;

- da perda de crédito no mercado financeiro, hoje pressionado pelas coobrigações ambientais; ou

- de penalidades governamentais de natureza decisiva, como imposição de encerramento das atividades, ou multas de valores substanciais e de grande impacto no fluxo de caixa das companhias.

Assim como todos os gastos, os investimentos nesta área necessitam de um processo de avaliação, antes e depois de sua adição, devendo prever: 
- definição dos impactos sobre o meio ambiente, gerados pelas atividades da empresa, com especificação do motivo, da área e do momento onde tais impactos têm origem e/ou onde se concentram;

- investigação das alternativas tecnológicas disponíveis no mercado, seja na forma de produtos ou de serviços, para solucioná-lo; e

- avaliação técnica e econômico-financeira da possibilidade de uma implementação gradativa, se necessário, e os resultados que podem ser obtidos a partir da implementação de cada etapa.

A aquisição e implementação do sistema de controle e preservação ambiental, qualquer que seja sua forma, pressupõem que o comprador tenha informações quanto à sua viabilidade técnica, vida útil e benefícios que podem ser esperados.

A implementação ou aquisição, por si só, não resolve os problemas da empresa; em menor ou maior escala, precisa de um processo de análise e avaliação, no sentido de verificar se os resultados esperados estão se concretizando e, caso contrário, investigar a razão das falhas ocorridas e tomar as medidas necessárias para sua correção.

O funcionamento adequado do sistema implementado garante o resultado de uma operação ou processo, e os objetivos da empresa, qual seja: produzir com qualidade ambiental.

Uma falha em uma etapa no processo operacional pode ter conseqüências no resultado global da empresa, como, por exemplo, a perda de um lote inteiro de produção ou retrabalho do mesmo.

Qualquer falha em um dos segmentos de uma empresa pode implicar falha de atendimento ao cliente, o que pode comprometer as condições de continuidade da empresa ou, no mínimo, gerar aumento de custos e/ou perda de receitas. 
O processo de avaliação deve ser feito em termos técnicos: sob os aspectos de adequação e físicos (volume de resíduos poluentes reduzidos) e em termos econômico-financeiros, visto que há casos ou momento em que o fluxo de recursos passíveis de disponibilização não comporta, de imediato, os investimentos totais; nesse caso, tais gastos devem ser incluídos na programação de fluxo de caixa da empresa.

Após a implementação do sistema de controle ambiental, a avaliação física e a monetária continuam se complementando. A avaliação sob os aspectos físicos compreende os dados de natureza técnica: forma de funcionamento e resultados produzidos.

Os resultados restritos ao ponto de vista técnico são insuficientes para avaliar o desempenho do empreendimento; uma avaliação de custos da manutenção de um equipamento defasado em relação aos avanços tecnológicos necessita da análise econômico-financeira. Não basta saber que a produção vai aumentar ou diminuir; é preciso conhecer que sacrifício financeiro demandará e qual a disponibilidade de recursos. Por outro lado, a informação de custo ambiental, por si só, não informa o nível de adequação dos equipamentos ou sistemas em si; necessário se faz mensurar fisicamente para saber se os sistemas implantados estão correspondendo ao esperado.

Assim, investir é necessário, e controlar o desempenho e resultados dos investimentos é tão importante quanto a decisão de investir, pois, estrategicamente, sempre é tempo de corrigir falhas. Um erro corrigido na etapa inicial de um processo pode assegurar a qualidade final deste, bem como evitar custos de correção de falhas, reprocessamento de produtos ou perda total desse processo.

Com a utilização do custeio por atividades, os custos ambientais serão definidos a partir da identificação e mensuração dos recursos consumidos pelas atividades de controle, preservação e recuperação ambiental. 
Desta forma, os gestores da empresa passam a ter informações sobre todos os aspectos inerentes à função de proteção ambiental, como, por exemplo:

- os custos de cada uma das atividades necessárias ao processo;

- os custos de todo o processo de trabalho desenvolvido;

- os custos de todas as atividades desenvolvidas pela função, independentemente dos processos que as exigiram;

- resultado dos centros de custos responsáveis por atividades de controle ambiental;

- os custos ambientais incorridos durante todo um ciclo de vida de produtos.

Além disso, podem ter informações quanto à localização física das atividades, forma de integração dos centros de custos, evolução temporal dos custos de controle ambiental em si, em produtos, em atividades e em processos.

Sob a ótica dos aspectos técnicos, estas informações são cruciais no desenvolvimento dos projetos de eliminação gradativa dos efeitos danosos da produção, bem como para tomar conhecimento de eventuais retrocessos. Normalmente, falhas dos processos operacionais que poluem o meio ambiente não podem ser sanadas de uma única vez; há a necessidade de um tratamento, ou substituição de máquinas e equipamentos de forma gradativa. $\mathrm{O}$ processo de melhorias exige a identificação das falhas e pontos fracos passados para a tomada de medidas corretivas.

Do ponto de vista da gestão econômica global da empresa, a gestão estratégica de custos ambientais identifica o nível de eficiência e eficácia dos resultados que consumiram atividades e, portanto, recursos. Os pontos fracos devem ser investigados e sanados, enquanto os pontos fortes devem ser otimizados ou, no mínimo, mantidos. 


\subsection{Identificando os Custos Ambientais}

Custos ambientais são representados pelo somatório de todos os custos dos recursos utilizados pelas atividades desenvolvidas com o propósito de controle, preservação $e$ recuperação ambiental

Utilizando-se os conceitos contábeis já existentes quanto à segregação dos custos dos produtos - diretos, indiretos -, deve ser estabelecido um objeto de custeio específico, que são as atividades de controle, preservação e recuperação ambiental. Estas serão, então, classificadas em atividades diretas e indiretas.

As atividades diretas serão todas aquelas objetivamente identificadas como pertinentes ao controle, preservação e recuperação ambiental. Observe-se que estas atividades podem estar indiretamente associadas à elaboração do produto; contudo, estão diretamente associadas ao processo de controle, preservação e recuperação do meio ambiente. Os exemplos são os tradicionais: mão-de-obra, insumos antipoluentes, depreciação de equipamentos antipoluentes etc.

As atividades indiretas serão aquelas que existem para dar suporte à preservação ambiental (salário de supervisores, aluguel da área ocupada, recursos consumidos nas atividades de compras, de tesouraria etc.)

Nas empresas em que a operacionalização do sistema de proteção ambiental ocorre em múltiplas etapas do processo de produção, os custos da área operacional devem ser colhidos nos centros de custos onde as atividades ambientais ocorrem, devendo ser implantados sistemas de acumulação de horas-máquina e de mão-de-obra específicos para o tempo consumido com as atividades de natureza ambiental, segregação dos equipamentos antipoluentes para apuração do valor da depreciação dos mesmos, quantificação dos insumos necessários à sua operacionalização e implantação de instrumentos para apuração do consumo de energia e de água. 


\subsection{Direcionadores de Custos das Atividades de Controle, Preservação e Recuperação Ambiental}

$\mathrm{O}$ estabelecimento do direcionador de custo das atividades ambientais requer a identificação da relação causal da atividade e do seu custo, por meio da apuração do fator de produção consumido pela atividade e da atribuição de uma medida para o mesmo. Por exemplo, uma rotina de controle ambiental requer uma quantidade de horas-homem trabalhadas. Neste caso, a relação causal entre a atividade e o seu custo é o uso de mão-deobra. O fator de produção consumido pela atividade é "horas-homem trabalhadas". A quantidade de horas-homem trabalhadas é a medida do fator de produção. O custo ambiental, neste caso, será obtido a partir da multiplicação da quantidade de fatores de produção (quantidade de horas trabalhadas) pela taxa horária do salário do empregado.

Exemplos de medidas de produção, normalmente estabelecidas para o custeio das atividades e que se adaptam perfeitamente ao custeio do controle ambiental são:

\begin{tabular}{ll}
\hline Fator de produção & Medida \\
Pessoal & Tempo \\
Tecnologia & Horas de máquina/tecnologia \\
Instalações & Área \\
Utilidades & Quilowatt/hora \\
\hline Fonte: BRIMSON, 1996, p. 153 &
\end{tabular}

Desta forma, ter-se-ia como direcionadores de custos, no exemplo acima, a quantidade de tempo despendida pelos funcionários para cada atividade de controle ambiental; a quantidade de horas-máquina utilizadas; a área ocupada para a realização das mesmas; e o consumo de quilowatts requerido. 


\subsection{Estrutura do Custeio para a Função de Controle Ambiental}

De acordo com a estrutura básica do custeio por atividades, os objetos de custos devem ser identificados. Assim, definir-se-á estes objetos em uma situação hipotética bastante simplificada.

\section{Situação hipotética 1}

Em uma empresa de transformação, onde há o uso de matéria-prima poluente, a preservação e o controle ambiental se faz pela inclusão de insumos adicionais ao processo produtivo, visando à eliminação dos resíduos gerados pela matéria-prima, concomitantemente ao desenvolvimento do processo operacional. Finda cada atividade de produção, há um centro de custos responsável pela triagem do produto para verificar o teor de substâncias poluentes que ficaram no mesmo, ou seja, há um controle de qualidade ambiental.

A decisão de reduzir o nível de resíduos tóxicos do processo produtivo gera um processo de controle e preservação do meio ambiente, o qual se inicia com os estudos do processo operacional para identificação das técnicas, procedimentos e produtos adequados para eliminar (ou reduzir) tais resíduos. Neste estágio, verificam-se as atividades que consomem mão-de-obra e insumos.

De posse do resultado destes estudos, o departamento responsável pelo controle, preservação e recuperação ambiental solicita ao departamento de compras a aquisição dos recursos especificados. Este realiza uma pesquisa para identificar os possíveis fornecedores; seleciona aquele que oferece as melhores condições em termos de especificações técnicas, qualidade e preço e, por fim, consuma a compra.

O departamento de recebimento recepciona os produtos, verificando as especificações técnicas, qualidade e quantidade. Em seguida, há o envio para o estoque. 
No departamento de estocagem, os produtos são armazenados e mantidos até o recebimento de uma requisição da área de produção.

No momento adequado, o departamento de produção solicita o envio de uma determinada quantidade deste produto. Uma vez recebido, ele será inserido no processo operacional, conforme a quantidade especificada, em um processo bastante simplificado, que consiste unicamente da introdução manual deste insumo no processo operacional já em andamento.

Na saída da produção, há uma avaliação das condições técnicas finais, especificamente quanto à permanência de resíduos tóxicos no produto.

Observa-se, nesta situação hipotética, procedimentos específicos destinados ao controle ambiental, que poderiam ser assim identificados:

- $\mathbf{1}^{\mathrm{a}}$ atividade - buscar os pontos do processo operacional que originam a produção de resíduos poluentes:

\begin{tabular}{|l|l|}
\hline Função & $\begin{array}{l}\text { Controle, preservação e recuperação } \\
\text { ambiental }\end{array}$ \\
\hline Processo & Preservação do meio ambiente \\
\hline Atividade & $\begin{array}{l}\text { Estudo do projeto de produção para verificar } \\
\text { o que causa a poluição }\end{array}$ \\
\hline Tarefa & $\begin{array}{l}\text { Selecionar os pontos passíveis de produção de } \\
\text { resíduos poluentes }\end{array}$ \\
\hline Operação & $\begin{array}{l}\text { Visitar pontos passíveis de produção de } \\
\text { resíduos poluentes }\end{array}$ \\
\hline Elemento e informação: & $\begin{array}{l}\text { Identificação do pontos passíveis de produção } \\
\text { de resíduos poluentes } \\
\text { Tipos e quantificação dos resíduos produzidos } \\
\text { Nível de atendimento aos padrões ambientais }\end{array}$ \\
\hline Adaptação de: BRIMSON (1996, p. 64).
\end{tabular}


$2^{\mathrm{a}}$ atividade - identificar os meios para eliminar a produção de resíduos poluentes:

\begin{tabular}{|l|l|}
\hline Função & $\begin{array}{l}\text { Controle, preservação e recuperação } \\
\text { ambiental }\end{array}$ \\
\hline Processo & Preservação do meio ambiente \\
\hline Atividade & $\begin{array}{l}\text { Identificação dos produtos que tenham } \\
\text { condições para eliminar o resíduo produzido }\end{array}$ \\
\hline Tarefa & Selecionar alternativa mais adequada \\
\hline Operação & $\begin{array}{l}\text { Testar alternativa escolhida/Definir forma de } \\
\text { aplicação/uso }\end{array}$ \\
\hline Elemento e informação: & $\begin{array}{l}\text { Identificação do insumo antipoluente } \\
\text { Estabelecimento do processo de uso/aplicação }\end{array}$ \\
\hline Adaptação de: BRIMSON (1996, p. 64).
\end{tabular}

- $3^{\mathrm{a}}$ atividade - identificar os fornecedores habilitados para atender às necessidades determinadas:

\begin{tabular}{|l|l|}
\hline Função & $\begin{array}{l}\text { Controle, preservação e recuperação } \\
\text { ambiental }\end{array}$ \\
\hline Processo & Preservação do meio ambiente \\
\hline Atividade & Pesquisa de fornecedores \\
\hline Tarefa & $\begin{array}{l}\text { Pesquisar empresas que comercializem o } \\
\text { produto procurado }\end{array}$ \\
\hline Operação & Fazer contatos telefônicos \\
\hline Elemento e informação: & Fornecedores do produto em questão \\
\hline Adaptação de: BRIMSON (1996, p. 64).
\end{tabular}


- $4^{\mathrm{a}}$ atividade - selecionar os fornecedores habilitados para atender às necessidades determinadas:

\begin{tabular}{|l|l|}
\hline Função & $\begin{array}{l}\text { Controle, preservação e recuperação } \\
\text { ambiental }\end{array}$ \\
\hline Processo & Preservação do meio ambiente \\
\hline Atividade & Seleção de fornecedores \\
\hline Tarefa & $\begin{array}{l}\text { Selecionar entre os fornecedores aquele que } \\
\text { melhor atenda às condições estabelecidas }\end{array}$ \\
\hline Operação & Comparação de dados \\
\hline Elemento e informação: & Fornecedor do produto em questão \\
\hline Adaptação de: BRIMSON (1996, p. 64).
\end{tabular}

- $5^{\mathrm{a}}$ atividade - efetivar a compra:

\begin{tabular}{|l|l|}
\hline Função & $\begin{array}{l}\text { Controle, preservação e recuperação } \\
\text { ambiental }\end{array}$ \\
\hline Processo & Preservação do meio ambiente \\
\hline Atividade & Compras de insumos antipoluentes \\
\hline Tarefa & $\begin{array}{l}\text { Preparar especificações para elaboração do } \\
\text { pedido de compra }\end{array}$ \\
\hline Operação & Emitir pedido de compra \\
\hline Elemento e informação: & Pedido de compra \\
\hline Adaptação de: BRIMSON (1996, p. 64).
\end{tabular}


- $6^{\mathrm{a}}$ atividade - a recepção:

\begin{tabular}{|l|l|}
\hline Função & $\begin{array}{l}\text { Controle, preservação e recuperação } \\
\text { ambiental }\end{array}$ \\
\hline Processo & Preservação do meio ambiente \\
\hline Atividade & Recebimento das Compras \\
\hline Tarefa & $\begin{array}{l}\text { Verificar atendimento de qualidade, } \\
\text { especificações técnicas e quantidade }\end{array}$ \\
\hline Operação & $\begin{array}{l}\text { Inspecionar características dos produtos } \\
\text { recebidos }\end{array}$ \\
\hline Elemento e informação: & $\begin{array}{l}\text { Nível de atendimento das características } \\
\text { solicitadas } \\
\text { Devolução por não atendimento } \\
\text { Volume de entrada em estoques } \\
\text { Valor financeiro da transação }\end{array}$ \\
\hline
\end{tabular}

Adaptação de: BRIMSON (1996, p. 64).

- $7^{\mathrm{a}}$ atividade - despacho dos produtos recebidos para o estoque

\begin{tabular}{|l|l|}
\hline Função & $\begin{array}{l}\text { Controle, preservação e recuperação } \\
\text { ambiental }\end{array}$ \\
\hline Processo & Preservação do meio ambiente \\
\hline Atividade & Envio dos produtos para o estoque \\
\hline Tarefa & Preparar condições para transporte \\
\hline Operação & Transportar para o estoque \\
\hline Elemento e informação: & Controle das Quantidades enviadas \\
\hline Adaptação de: BRIMSON (1996, p. 64).
\end{tabular}


- $8^{\text {a }}$ atividade - envio da nota fiscal para o departamento de contas a pagar:

\begin{tabular}{|l|l|}
\hline Função & $\begin{array}{l}\text { Controle, preservação e recuperação } \\
\text { ambiental }\end{array}$ \\
\hline Processo & Preservação do meio ambiente \\
\hline Atividade & $\begin{array}{l}\text { Envio da nota fiscal para o departamento de } \\
\text { contas a pagar }\end{array}$ \\
\hline Tarefa & $\begin{array}{l}\text { Destacar pessoal para entrega da nota fiscal ao } \\
\text { departamento de contas a pagar }\end{array}$ \\
\hline Operação & Entregar a nota fiscal \\
\hline Elemento e informação: & Protocolo de entrega \\
\hline Adaptação de: BRIMSON (1996, p. 64).
\end{tabular}

- $9^{\text {a }}$ atividade - 0 armazenamento dos produtos recebidos em estoques:

\begin{tabular}{|l|l|}
\hline Função & $\begin{array}{l}\text { Controle, preservação e recuperação } \\
\text { ambiental }\end{array}$ \\
\hline Processo & Preservação do meio ambiente \\
\hline Atividade & Estocagem dos produtos recebidos \\
\hline Tarefa & Armazenar produtos em local apropriado \\
\hline Operação & Guarda dos produtos \\
\hline Elemento e informação: & Quantidade recebida/disponível \\
\hline Adaptação de: BRIMSON (1996, p. 64).
\end{tabular}


- $10^{\mathrm{a}}$ atividade - pedido do departamento de produção:

\begin{tabular}{|l|l|}
\hline Função & $\begin{array}{l}\text { Controle, preservação e recuperação } \\
\text { ambiental }\end{array}$ \\
\hline Processo & Preservação do meio ambiente \\
\hline Atividade & Solicitação de insumos antipoluentes \\
\hline Tarefa & $\begin{array}{l}\text { Preparar pedido com especificações e } \\
\text { quantidades }\end{array}$ \\
\hline Operação & Emitir pedido \\
\hline Elemento e informação: & Requisição para consumo \\
\hline Adaptação de: BRIMSON (1996, p. 64).
\end{tabular}

- $11^{\mathrm{a}}$ atividade - atendimento do pedido do departamento de produção:

\begin{tabular}{|l|l|}
\hline Função & $\begin{array}{l}\text { Controle, preservação e recuperação } \\
\text { ambiental }\end{array}$ \\
\hline Processo & Preservação do meio ambiente \\
\hline Atividade & Fornecer insumos solicitados \\
\hline Tarefa & Separar produtos requisitados \\
\hline Operação & Entregar produtos \\
\hline Elemento e informação: & $\begin{array}{l}\text { Volume entregue } \\
\text { Baixa de quantidades disponíveis }\end{array}$ \\
\hline Adaptação de: BRIMSON (1996, p. 64).
\end{tabular}


- $12^{\mathrm{a}}$ atividade - inserção dos produtos no ponto determinado do processo operacional:

\begin{tabular}{|l|l|}
\hline Função & $\begin{array}{l}\text { Controle, preservação e recuperação } \\
\text { ambiental }\end{array}$ \\
\hline Processo & Preservação do Meio Ambiente \\
\hline Atividade & Inserção de insumos antipoluentes \\
\hline Tarefa & $\begin{array}{l}\text { Selecionar e preparar os insumos para evitar } \\
\text { danos ao meio ambiente }\end{array}$ \\
\hline Operação & $\begin{array}{l}\text { inserir insumos antipoluentes, } \\
\text { concomitantemente ao processo operacional }\end{array}$ \\
\hline Elemento e informação: & $\begin{array}{l}\text { Quantidade produzida } \\
\text { Insumos consumidos }\end{array}$ \\
\hline Adaptaç̃o de: BRIMSON (1996, p. 64) &
\end{tabular}

- $13^{\mathrm{a}}$ atividade - controle da qualidade ambiental da produção:

\begin{tabular}{|l|l|}
\hline Função & $\begin{array}{l}\text { Controle, preservação e recuperação } \\
\text { ambiental }\end{array}$ \\
\hline Processo & Preservação do Meio Ambiente \\
\hline Atividade & $\begin{array}{l}\text { Verificar níveis de qualidade ambiental } \\
\text { atingidos }\end{array}$ \\
\hline Tarefa & $\begin{array}{l}\text { Verificar nível de resíduos existente no } \\
\text { produto final }\end{array}$ \\
\hline Operação & Realizar teste técnico, pesagem \\
\hline Elemento e informação: & $\begin{array}{l}\text { Resíduos produzidos } \\
\text { Nível de eficiência/eficácia } \\
\text { Insumos consumidos }\end{array}$ \\
\hline Adaptação de: BRIMSON (1996, p. 64).
\end{tabular}


- atividade referente ao pagamento do fornecedor, a qual ocorre em algum momento do processo:

\begin{tabular}{|l|l|}
\hline Função & $\begin{array}{l}\text { Controle, preservação e recuperação } \\
\text { ambiental }\end{array}$ \\
\hline Processo & Preservação do Meio Ambiente \\
\hline Atividade & $\begin{array}{l}\text { Pagamento de nota fiscal relativa à compra de } \\
\text { insumos antipoluentes }\end{array}$ \\
\hline Tarefa & Preparar processo de pagamento \\
\hline Operação & Emissão de cheque \\
\hline Elemento e informação: & Baixa de contas a pagar \\
\hline Adaptação de: BRIMSON (1996 - p. 64).
\end{tabular}

Observa-se, neste exemplo dado às simplificações, que as atividades consomem mão-deobra de seus executores (e os devidos encargos sociais), e insumos necessários para tal, como o produto antipoluente adquirido e material de escritório para documentação do processo. 
Síntese do Processo de Preservação do Meio Ambiente

\begin{tabular}{|c|c|c|c|c|c|c|c|}
\hline \multicolumn{8}{|c|}{ DEPARTAMENTOS/ATIVIDADES } \\
\hline Eng $^{\mathrm{a}}$ & Compras & Recepção & Estoques & Produção & $\begin{array}{l}\text { Controle } \\
\text { de } \\
\text { Qualidade } \\
\text { Ambiental }\end{array}$ & $\begin{array}{l}\text { Contas a } \\
\text { pagar }\end{array}$ & $\begin{array}{l}\text { Totais por } \\
\text { Atividade }\end{array}$ \\
\hline \multicolumn{8}{|l|}{$\begin{array}{l}1^{\mathrm{a}} \\
\text { atividade }\end{array}$} \\
\hline \multicolumn{8}{|l|}{$\begin{array}{l}2^{\mathrm{a}} \\
\text { atividade }\end{array}$} \\
\hline & $\begin{array}{l}3^{\mathrm{a}} \\
\text { atividade }\end{array}$ & & & & & & \\
\hline & $\begin{array}{l}4^{\mathrm{a}} \\
\text { atividade }\end{array}$ & & & & & & \\
\hline & $\begin{array}{l}5^{\mathrm{a}} \\
\text { atividade }\end{array}$ & & & & & & \\
\hline & & $\begin{array}{l}6^{\mathrm{a}} \\
\text { atividade }\end{array}$ & & & & & \\
\hline & & $\begin{array}{l}7^{\mathrm{a}} \\
\text { atividade }\end{array}$ & & & & & \\
\hline & & $\begin{array}{l}8^{\mathrm{a}} \\
\text { atividade }\end{array}$ & & & & & \\
\hline & & & $\begin{array}{l}9^{\mathrm{a}} \\
\text { atividade }\end{array}$ & & & & \\
\hline & & & & $\begin{array}{l}10^{\mathrm{a}} \\
\text { atividade }\end{array}$ & & & \\
\hline & & & $\begin{array}{l}11^{\mathrm{a}} \\
\text { atividade }\end{array}$ & & & & \\
\hline & & & & $\begin{array}{l}12^{\mathrm{a}} \\
\text { atividade }\end{array}$ & & & \\
\hline & & & & & $\begin{array}{l}13^{\mathrm{a}} \\
\text { atividade }\end{array}$ & & \\
\hline & & & & & & pagto NF & \\
\hline $\begin{array}{l}\text { Custo das } \\
\text { atividades } \\
\text { por área de } \\
\text { trabalho }\end{array}$ & $\begin{array}{l}\text { Custo das } \\
\text { atividades } \\
\text { por área de } \\
\text { trabalho }\end{array}$ & $\begin{array}{l}\text { Custo das } \\
\text { atividades } \\
\text { por área de } \\
\text { trabalho }\end{array}$ & $\begin{array}{l}\text { Custo das } \\
\text { atividades } \\
\text { por área de } \\
\text { trabalho }\end{array}$ & $\begin{array}{l}\text { Custo das } \\
\text { atividades } \\
\text { por área de } \\
\text { trabalho }\end{array}$ & $\begin{array}{l}\text { Custo das } \\
\text { atividades } \\
\text { por área de } \\
\text { trabalho }\end{array}$ & $\begin{array}{l}\text { Custo das } \\
\text { atividades } \\
\text { por área de } \\
\text { trabalho }\end{array}$ & $\begin{array}{l}\text { Custo total } \\
\text { do processo }\end{array}$ \\
\hline
\end{tabular}


Esta síntese demonstra a apuração dos custos por atividade, por centro de custos e o custo total de um processo. O custo do ciclo de vida será composto pelo somatório de todos os processos realizados durante o período de manutenção do produto.

Para identificação das atividades da área ambiental e rastreamento de seus custos, deve haver um apontamento de horas de trabalho necessárias para a execução de tais tarefas, como as horas de engenharia, de compras, da recepção, do almoxarifado, do operário que realiza a inserção do insumo e do departamento de contas a pagar.

Naturalmente, deve ser computado, sempre que economicamente viável, o consumo de energia elétrica ocorrido em cada fase, uma parcela do custo do aluguel em função do tempo requerido para a execução da atividade, e outros custos indiretos, mas essenciais ao controle ambiental.

Desta forma, o custo das atividades relativas ao processo de eliminação dos danos ao meio ambiente é composto pelo somatório dos custos de todas as atividades retrodescritas.

A análise dos custos destas atividades pode identificar, ou não, irregularidades no consumo dos insumos básicos, ou de mão-de-obra, dado que há um custo orçado, em função do padrão técnico previamente desenvolvido, assim como variáveis ou oscilações dos demais custos. Estas, se significativas, devem ser investigadas, no sentido de se identificar eventuais falhas na operacionalização do sistema ou nas designações iniciais quanto aos recursos necessários.

Importantes subsídios para a continuidade do sistema de gerenciamento ambiental podem ser gerados pela análise dos custos das atividades específicas de controle ambiental. 


\section{Situação hipotética 2}

Trata-se de uma situação cujo objetivo é a preservação do meio ambiente, sendo o tratamento de resíduos produzidos, após a conclusão do processo operacional, um departamento à parte.

Supõe-se ainda que os resíduos sejam automaticamente enviados para uma determinada área, na qual os insumos antipoluentes serão agregados, para então ocorrer o processo de eliminação dos resíduos tóxicos.

Findo o processo de tratamento, o material residual é analisado para verificar o nível de sucesso obtido ou necessidade de reprocessamento.

Considera-se também que as atividades desenvolvidas pelos departamentos de engenharia, compras, recepção e estocagem são semelhantes aos descritos anteriormente.

$1^{a}$ atividade - estudos para verificação das características dos poluentes

\begin{tabular}{|l|l|}
\hline Função & Controle ambiental \\
\hline Processo & Preservação do meio ambiente \\
\hline Atividade & $\begin{array}{l}\text { Avaliação das características dos elementos } \\
\text { poluentes produzidos no processo } \\
\text { operacional }\end{array}$ \\
\hline Tarefa & Coletar amostras para análise \\
\hline Operação & Identificar e analisar tipos de poluentes \\
\hline Elemento e informação: & $\begin{array}{l}\text { Tipos de resíduos tóxicos existentes } \\
\text { Grau de comprometimento }\end{array}$ \\
\hline Adaptação de: BRIMSON (1996, p. 64).
\end{tabular}


- $2^{\mathrm{a}}$ atividade - pesquisas sobre os meios adequados para o combate os resíduos poluentes produzidos

\begin{tabular}{|l|l|}
\hline Função & Controle ambiental \\
\hline Processo & Preservação do meio ambiente \\
\hline Atividade & $\begin{array}{l}\text { Pesquisa sobre os mecanismos adequados } \\
\text { para o processo de eliminação dos resíduos }\end{array}$ \\
\hline Tarefa & $\begin{array}{l}\text { Verificar os tipos de produtos ou tecnologias } \\
\text { disponíveis no mercado habilitados à } \\
\text { eliminação dos resíduos identificados }\end{array}$ \\
\hline Operação & $\begin{array}{l}\text { Contatar fornecedores e instituições } \\
\text { especializadas }\end{array}$ \\
\hline Elemento e informação: & $\begin{array}{l}\text { Identificação dos meios úteis. } \\
\text { Grau esperado de eliminação. }\end{array}$ \\
\hline Adaptação de: BRIMSON (1996, p. 64). &
\end{tabular}

- $3^{\text {a }}$ atividade - seleção dos mecanismos adequados

\begin{tabular}{|l|l|}
\hline Função & Controle ambiental \\
\hline Processo & Preservação do meio ambiente \\
\hline Atividade & Seleção das alternativas mais adequadas \\
\hline Tarefa & $\begin{array}{l}\text { Selecionar insumos e equipamentos } \\
\text { necessários à desintoxicação }\end{array}$ \\
\hline Operação & Escolher melhor alternativa \\
\hline Elemento e informação: & $\begin{array}{l}\text { Definição dos instrumentos a serem } \\
\text { utilizados } \\
\text { Tempo estimado para realização do trabalho } \\
\text { Estimativa de grau de atendimento aos } \\
\text { padrões ambientais }\end{array}$ \\
\hline Adaptacão de: BRIMSON (1996, p. 64). &
\end{tabular}

- $4^{\mathrm{a}}$ atividade - tratamento dos resíduos poluentes 


\begin{tabular}{|l|l|}
\hline Função & Controle ambiental \\
\hline Processo & Preservação do meio ambiente \\
\hline Atividade & Tratamento de resíduos poluentes \\
\hline Tarefa & Preparar insumos necessários ao tratamento \\
\hline Operação & $\begin{array}{l}\text { Aplicar os insumos sobre os resíduos } \\
\text { poluentes }\end{array}$ \\
\hline Elemento e informação: & $\begin{array}{l}\text { Eliminação de resíduos tóxicos aden padrões } \\
\text { Nível de atendimento aos } \\
\text { ambientais }\end{array}$ \\
\hline Adaptação de: BRIMSON (1996, p. 64). &
\end{tabular}

\section{- $5^{\mathrm{a}}$ atividade - verificação dos níveis de qualidade ambiental obtido}

\begin{tabular}{|l|l|}
\hline Função & Controle ambiental \\
\hline Processo & Preservação do meio ambiente \\
\hline Atividade & Controle de qualidade ambiental \\
\hline Tarefa & Verificar nível de eliminação da toxicidade \\
\hline Operação & $\begin{array}{l}\text { Mensurar tecnicamente as características } \\
\text { poluentes }\end{array}$ \\
\hline Elemento e informação: & $\begin{array}{l}\text { Sucesso das atividades empreendidas } \\
\text { Nível de atendimento aos padrões } \\
\text { ambientais }\end{array}$ \\
\hline
\end{tabular}

Vê-se, neste caso, que as atividades de tratamento de resíduos tóxicos ocorrem de forma independente do processo produtivo. Assim sendo, a coleta de dados sobre as mesmas exige um menor esforço, em função de estarem segregadas em um departamento com o objetivo específico de preservação e controle ambiental, mas que, semelhantemente ao exemplo anterior, requer a apuração da quantidade de horas trabalhadas e insumos consumidos. 
Ainda neste caso tem-se o custo da depreciação como sendo específico do controle ambiental, conforme o volume de horas-máquina consumido em cada processo.

\section{Situação hipotética 3}

Tentando visualizar a situação de recuperação de um dano ambiental específico, como a recuperação de uma área degradada, e omitindo as atividades indiretas já mencionadas anteriormente na situação hipotética 1, ocorridas nas áreas de recepção, estoques, contas a pagar etc, ter-se-ia seguinte estrutura:

- $\mathbf{1}^{\mathrm{a}}$ atividade - estudos para verificação das características dos poluentes

\begin{tabular}{|l|l|}
\hline Função & Controle ambiental \\
\hline Processo & Recuperação ambiental \\
\hline Atividade & $\begin{array}{l}\text { Avaliação das características dos elementos } \\
\text { poluentes contidos na área contaminada }\end{array}$ \\
\hline Tarefa & Coletar amostras para análise \\
\hline Operação & Identificar e analisar tipos de poluentes \\
\hline Elemento e informação: & $\begin{array}{l}\text { Tipos de resíduos tóxicos existentes } \\
\text { Grau de comprometimento }\end{array}$ \\
\hline Adaptação de: BRIMSON (1996, p. 64).
\end{tabular}


- $2^{\mathrm{a}}$ atividade - pesquisas sobre os meios adequados para o processo de desintoxicação

\begin{tabular}{|l|l|}
\hline Função & Controle ambiental \\
\hline Processo & Recuperação ambiental \\
\hline Atividade & Pesquisa sobre os mecanismos adequados \\
\hline Tarefa & $\begin{array}{l}\text { Verificar os tipos de produtos ou tecnologias } \\
\text { disponíveis no mercado capazes do maior } \\
\text { grau possível de recuperação da área afetada }\end{array}$ \\
\hline Operação & $\begin{array}{l}\text { Contatar fornecedores e instituições } \\
\text { especializadas }\end{array}$ \\
\hline Elemento e informação: & $\begin{array}{l}\text { Identificação dos meios úteis ao processo de } \\
\text { desintoxicação. } \\
\text { Grau esperado de recuperação. } \\
\text { Tempo exigido pelo processo }\end{array}$ \\
\hline
\end{tabular}

- $3^{\text {a }}$ atividade - seleção dos mecanismos adequados

\begin{tabular}{|l|l|}
\hline Função & Controle ambiental \\
\hline Processo & Recuperação ambiental \\
\hline Atividade & $\begin{array}{l}\text { Seleção dos mecanismos adequados para a } \\
\text { desintoxicação de área contaminada }\end{array}$ \\
\hline Tarefa & $\begin{array}{l}\text { Selecionar insumos e equipamentos } \\
\text { necessários à desintoxicação }\end{array}$ \\
\hline Operação & Escolher melhor alternativa \\
\hline Elemento e informação: & $\begin{array}{l}\text { Instrumentos a serem utilizados } \\
\text { Tempo estimado para realização do trabalho } \\
\text { Estimativa de grau de atendimento aos } \\
\text { padrões ambientais }\end{array}$ \\
\hline Adaptacão de: BRIMSON (1996, p. 64). &
\end{tabular}

- $4^{\mathrm{a}}$ atividade - aplicação dos procedimentos necessários à desintoxicação 


\begin{tabular}{|l|l|}
\hline Função & Controle ambiental \\
\hline Processo & Recuperação ambiental \\
\hline Atividade & Desintoxicação de área contaminada \\
\hline Tarefa & $\begin{array}{l}\text { Preparar insumos equipamentos } \\
\text { necessários à desintoxicação }\end{array}$ \\
\hline Operação & Aplicar os insumos \\
\hline Elemento e informação: & $\begin{array}{l}\text { Sucesso das atividades empreendidas } \\
\text { Nível de atendimento aos padrões } \\
\text { ambientais }\end{array}$ \\
\hline Adaptação de: BRIMSON (1996, p. 64). &
\end{tabular}

- $5^{\text {a }}$ atividade - verificação dos níveis de qualidade ambiental obtido

\begin{tabular}{|l|l|}
\hline Função & Controle ambiental \\
\hline Processo & Recuperação ambiental \\
\hline Atividade & Controle de qualidade ambiental \\
\hline Tarefa & Verificar nível de eliminação da toxicidade \\
\hline Operação & $\begin{array}{l}\text { Mensurar tecnicamente as características } \\
\text { poluentes }\end{array}$ \\
\hline Elemento e informação: & $\begin{array}{l}\text { Sucesso das atividades empreendidas } \\
\text { Nível de atendimento aos padrões } \\
\text { ambientais }\end{array}$ \\
\hline Adaptação de: BRIMSON (1996, p. 64).
\end{tabular}

Tal como todos os processos de controle, preservação e recuperação ambiental, este tipo de trabalho também terá suas peculiaridades, dependendo do tipo e extensão da área contaminada (terras, águas, ar), como também os procedimentos serão específicos dependendo do tipo de poluente que deve ser tratado, dos insumos e dos equipamentos. Contudo, o objeto de custeio são as atividades e o conjunto destas para se alcançar a recuperação desejada. 


\section{2 - GESTÃO ESTRATÉGICA DOS CUSTOS AMBIENTAIS}

A gestão ambiental tornou-se uma área estratégica, necessitando, portanto, como as demais áreas consideradas estratégicas (a produção, por exemplo), de um tratamento específico, tendo em vista a importância que adquiriu o controle ambiental, sua premência e o expressivo volume de recursos nele investidos.

A segregação dos custos de natureza ambiental é fundamental para apurar informações elementares no processo de gestão econômica da empresa.

As estratégias principais da empresa, nesta área, devem ser: reduzir ao mínimo possível, se não eliminar, a produção de resíduos poluentes; elevar ao máximo a produtividade com grau de qualidade ambiental crescente; manter sistemas de gerenciamento ambiental eficazes ao menor custo permitido

O controle de custos refletirá o nível de falhas existentes e o volume de gastos necessários para eliminar e/ou reduzir estas falhas, seja na forma de investimentos de natureza permanente, ou de insumos consumidos no processo operacional.

\subsection{Avaliação de Resultados e de Desempenho}

Todos os recursos consumidos para o controle e preservação ambiental devem ser apurados por atividades, o que pode implicar o somatório dos custos incorridos em vários centros de custos. Ou, num mesmo centro, pode-se apurar os custos de diversas atividades.

Posteriormente, os custos destas atividades, somados, representarão os custos do processo de controle, preservação e recuperação ambiental, informação esta que deverá ser detalhada por centros de custos e por produto. 
Assim, o gestor da área econômica terá condições para informar o custo do controle ambiental, o qual, comparado aos custos planejados (de forma adequada), resultará na informação no que diz respeito ao nível de eficiência e eficácia da área sob sua responsabilidade

Um nível adequado de eficiência e eficácia implica que o processo operacional e os produtos ou serviços da empresa estão atendendo aos padrões de qualidade planejados pela empresa, mediante o consumo apropriado de recursos e tempo, o que se supõe seja o nível exigido pelos clientes e, no mínimo, o determinado pelos padrões de qualidade ambiental normatizados, assegurando, conseqüentemente, a aceitabilidade da empresa pela comunidade externa e, em decorrência, sua continuidade.

Esse fato tem sido muitas vezes utilizado como instrumento de marketing para alavancar a imagem da empresa e de seus produtos.

Um nível de eficiência e eficácia não satisfatório implica que a empresa deve empregar mais e/ou melhores recursos no processo de controle ambiental. Essa inadequação evidencia a necessidade de análise dos pontos falhos e a aplicação de medidas corretivas imediatas no sentido de minimizar os eventuais efeitos adversos, ainda não concretizados.

O sistema de acumulação dos custos ambientais poderá, ainda, estar sistematizado no sentido de segregar os custos decorrentes das falhas do processo operacional no que tange ao controle ambiental. Aproveitando a segregação de custos sugerida por ROBLES (1992, p. 115), tem-se o seguinte:

Custos do Controle Ambiental

- Custos Ambientais de Prevenção

- Custos Ambientais de Avaliação 
Custos das Falhas do Controle Ambiental

- Custos Ambientais das Falhas Internas

- Custos Ambientais das Falhas Externas

Os custos de controle ambiental compreendem os gastos incorridos na implementação e manutenção do sistema de proteção ambiental, os quais ocorrem no departamento de gerenciamento ambiental e nas atividades executadas com vistas a dar operacionalização ao sistema, o que pode se traduzir nos custos totais de um único departamento, ou via somatório dos custos das atividades ambientais executadas em diversos departamentos da linha operacional.

Os custos das falhas do controle ambiental são aqueles incorridos para adequar o nível de eficiência e de eficácia da empresa, também chamados de custos da não conformidade, dado que se referem a reprocessamento de atividades e/ou processos, tratamento de resíduos poluentes e/ ou áreas contaminadas, e os custos inerentes à devolução de produtos por clientes (expedição, recepção, retorno ao estoque, compensações pela falha, descontos, abatimentos etc).

Ao gerenciar seu processo operacional, com atenção para os aspectos relativos ao controle de qualidade e de qualidade ambiental, a empresa estará identificando atividades que geram resíduos poluentes, os quais podem compreender, entre outros:

- desperdício de matéria-prima

- refugos

- sobras

Ao custear estes itens, estará atribuindo custo à ineficiência do processo de controle ambiental. Dentro de uma estrutura organizada, haverá um gestor responsável por tais custos (ineficiências), o qual terá por responsabilidade envidar todos os esforços necessários para corrigir falhas, de forma a minimizar ou eliminar tais custos. 
A atribuição destes custos aos gestores visa orientá-los no sentido de rever o processo e de maximizar o resultado da empresa.

O simples ato de eleger um responsável pelo desempenho ruim não é suficiente; necessário se faz estabelecer um parâmetro mais preciso, como: o que deve ser melhorado ou justificado pelo gestor, por exemplo, a variação entre o planejado e o executado.

Se a variação for negativa, algumas causas podem ser inferidas, como:

- falhas no processo operacional: técnicas ou humanas;

- uso de insumos inadequados;

- quantidade de insumos imprópria; ou, ainda;

- falhas no processo de planejamento, cuja causa pode ter origem no próprio planejamento ou nas informações prestadas pelos gestores de cada área operacional para a elaboração do mesmo. As falhas no planejamento podem ser decorrentes de erro na definição da natureza e amplitude dos problemas ambientais, escolha de insumos inadequados, especificações inadequadas quanto à qualificação da mão-de-obra etc.

As variações positivas também devem ser investigadas, pois estas podem envolver:

- esforços do gestor na otimização dos resultados;

- falhas no processo de planejamento. Neste caso, poderiam ser atribuídas, por exemplo, ao superdimensionamento da abrangência e/ou natureza do problema; superavaliação da quantidade de insumos necessária etc;

- novas oportunidades a serem exploradas.

A avaliação da gestão ambiental econômica da empresa pode se dar pela confrontação do volume de impactos ambientais em cada período, com o volume de:

- investimentos realizados em tecnologias antipoluentes, de natureza permanente; 
- matéria-prima específica, consumida para a proteção, preservação e recuperação ambiental;

- horas de mão-de-obra consumida;

- horas-máquina.

A partir desta análise, a empresa poderá realizar inferências sobre o volume de gastos necessários para controlar os efeitos adversos de seu processo operacional.

A perspectiva é a de que os impactos adversos tenham uma progressão oposta ao volume de investimentos no controle e preservação ambiental, isto é, nos custos de prevenção. Esta informação será útil em nível global, à medida que reflete o esforço da organização como um todo, e também por áreas de responsabilidade, quando deixa evidenciado o desempenho de cada gestor.

Outros parâmetros que, comparado aos itens retrocitados, poderiam servir de base para análise do desempenho ambiental da empresa ou de suas áreas de responsabilidade são:

- volume de reclamações/devoluções de produtos pelos clientes;

- a variação dos resultados planejados versus executados;

- a variação ocorrida entre o volume de resíduos poluentes previstos e os efetivamente ocorridos.

O uso de alguns insumos adicionais ao processo produtivo pode ensejar a redução no volume de resíduos poluentes. Assim sendo, o uso destes deve ser otimizado; se, ao contrário, não atender às expectativas previstas, cabe a análise da não redução, que pode se dar em função de insumos inadequados, quantidades não apropriadas etc.

O mesmo acontece com a mão-de-obra; esta deve ser qualificada ou treinada; se não ocorrer variação positiva no volume de poluentes, a justificativa para tal pode estar no nível 
de qualificação e/ou treinamentos, partindo-se da hipótese de que a tecnologia e os insumos adotados foram corretamente definidos.

Em tese, a variação nos volumes de resíduos poluentes acompanha à dos custos planejados versus realizados, a partir da premissa de que os gastos planejados foram definidos em bases técnica e cientificamente corretas. Todas as variações devem ser justificadas e verificadas suas causas, objetivando sempre a melhoraria dos resultados da empresa.

No planejamento estratégico, devem estar contidas as premissas básicas que precisam ser utilizadas para implementação da postura da empresa em relação ao meio ambiente. Por exemplo, a empresa deveria envidar todos os esforços necessários para equiparar os níveis de poluição ao permitidos pela legislação ou empregar todos os recursos cabíveis para eliminar os impactos negativos sobre o meio ambiente. Ou, ainda, poderia fixar um nível intermediário para adequar o volume de resíduos poluentes por ela produzidos.

O planejamento operacional recorrerá ao auxílio técnico da área de controle ambiental e de compras, para obter as informações essenciais para a viabilização de tal estratégia.

O planejamento operacional será elaborado a partir dos conceitos contábeis utilizados para apuração e avaliação de desempenho, oferecendo, portanto, condições para que os resultados mensurados econômica e financeiramente, orçados e realizados, possam ser confrontados para fins de avaliação das áreas e da empresa.

\subsection{A Importância das Informações Econômico-Financeiras dos Aspectos Ambientais}

A expectativa é a de que o avanço da tecnologia e a divulgação dos conhecimentos quanto ao potencial das tecnologias já existentes possa conduzir as empresas, ao longo do tempo, a eliminar definitivamente, ou pelo menos de forma considerável, os níveis de impactos negativos sobre o meio ambiente e, conseqüentemente, seus custos com o controle ambiental. 
Enquanto tal situação não se concretiza, é preciso que os gestores tenham informações exatas e apropriadas a respeito do desempenho da empresa no que tange ao controle ambiental, para fundamentar de forma eficaz as decisões relativas à alocação ou realocação de investimentos nas áreas carentes, garantindo qualidade, eficiência e produtividade dos processos operacionais e, com isso, o atendimento das exigibilidades do público externo à companhia relativamente ao nível de responsabilidade social que a empresa deve assumir.

A mensuração e o acompanhamento das etapas do ciclo de vida do produto, em termos físicos e monetários, identificando as atividades executadas na seqüência de desenvolvimento dos produtos, permitem à empresa identificar a distribuição dos custos e, especificamente, as fases e os procedimentos que geram a produção dos impactos ambientais. Esta informação subsidia o processo de avaliação e decisão no que tange aos gastos necessários para dar tratamento aos impactos referidos.

No caso de linha de produção de múltiplos produtos, possibilita a associação dos custos de natureza ambiental às atividades, aos processos, áreas de responsabilidade e produtos responsáveis pela sua geração.

A Contabilidade por Atividades permite a elaboração de informações de extrema importância para a gestão ambiental e econômica da empresa, como os gastos ambientais, separados em investimentos, custos, despesas e perdas. Possibilita, também, o acompanhamento e a análise de todas as atividades relacionadas com o gerenciamento e, conseqüentemente, com a utilidade e importância financeira e técnica do processo. Propicia, ademais, a visualização dos benefícios decorrentes dos gastos incorridos, de forma geral em cada atividade, processo, função, produto e ciclo de vida destes.

Com tudo isto, a Contabilidade por Atividades dos custos ambientais passa a ter um papel fundamental no processo de redução e eliminação dos custos da empresa e otimização de seus resultados. 
Vale ressaltar ainda a grande importância do custeamento dos gastos ambientais por ciclo de vida. Os resultados de cada período dão à empresa uma visão vertical, possibilitando-lhe analisar o volume de recursos consumidos comparativamente aos resultados obtidos em termos econômico, financeiro, físico ou social. A visão horizontal dos custos com o meio ambiente, ou seja, seu comportamento ao longo do ciclo de vida, permite a visualização da evolução dos esforços empreendidos e a eficácia destes. 


\section{VII - CONCLUSÕES}

O trabalho teve por objetivo demonstrar que a Contabilidade por Atividades, ou custeio por atividades, é o sistema que melhor se adequa para identificar e mensurar os custos ambientais incorridos em uma empresa.

Em vista disso, procurou-se enfatizar a necessidade da inclusão dos referidos custos na gestão econômica da empresa, em face da grande relevância que estes têm sobre a continuidade da mesma, tanto em termos econômico-financeiros como do ponto de vista das exigências externas no que concerne à responsabilidade social da companhia, configuradas pelas pressões do mercado nacional e internacional, dos legisladores, dos concorrentes e da sociedade em geral.

Assim, ressaltou-se ser indispensável a integração dos sistemas de gerenciamento ambiental e de gestão estratégica de custos, dado que o primeiro consome recursos, enquanto que a gestão estratégica de custos trata, de forma geral, dos recursos consumidos pela empresa.

Os investimentos na área ambiental tornaram-se compulsórios, diante das crescentes e rigorosas exigências dos vários elementos com quem a empresa interage no seu dia-a-dia.

Os gastos na área ambiental, seja na forma preventiva, de controle ou de recuperação, têm significativo impacto sobre o patrimônio das empresas e, por esta razão, devem ser alvo de criteriosas estratégias, de forma a garantir o sucesso dos sistemas de gerenciamento ambiental adotados pelas companhias e, conseqüentemente, a continuidade dos negócios destas. 
A gestão estratégica de custos tem se mostrado uma necessidade premente para a conquista e manutenção de espaços no mercado nacional e internacional, cuja concorrência torna-se cada vez mais acirrada.

E a Contabilidade por Atividades tem um papel importante, porquanto pode proporcionar informações valiosas para a gestão econômica da empresa, ao custear a menor unidade de consumo de recursos, que são as atividades. Estas consomem os recursos; portanto, o custo destes recursos devem ser apropriados às atividades que os exigiram. Os produtos e processos consomem atividades, recebendo, por conseguinte, os custos dos recursos consumidos pelas mesmas. Usando-se esta metodologia elimina-se, consideravelmente, a necessidade de rateio dos custos indiretos e, conseqüentemente, as arbitrariedades provocadas pelo subjetivismo da escolha dos parâmetros para a distribuição de tais custos e se identifica, por fim, os custos ambientais em função das atividades inerentes ao controle ambiental executadas.

O correto custeamento das atividades relativas ao controle, preservação e recuperação ambiental pode resultar na redução de custos, em função da eliminação de perdas e desperdícios de recursos, como também o aumento de receitas em decorrência de melhorias que podem ser implantadas a partir da identificação de falhas na utilização dos recursos.

O conhecimento dos custos reais na área ambiental, principalmente a forma como se distribuem no processo operacional, proporciona condições para o estudo, análise e avaliação do grau de essencialidade das atividades desenvolvidas, do montante de capital consumido pelos processos de proteção ambiental, evidenciando, conseqüentemente, a partir da análise da relação custo/benefício, a necessidade de reestruturação, de novos investimentos, além de fornecer subsídios para a tomada de decisão sobre ser ou não necessário buscar capital adicional para atender tais necessidades.

Informações quanto ao consumo de recursos pelas atividades de proteção ambiental e pelos produtos possibilitam melhores condições para a determinação de preço e ainda uma real avaliação dos custos/benefícios gerados pela sua manutenção. 
A análise dos custos das atividades ambientais consumidas pelos processos de trabalho realizados pela companhia permite uma avaliação mais pormenorizada quanto à forma de consumo dos recursos, bem como a localização do estágio em que ocorre; isto auxilia, entre outras estratégias, a de estocagem, no que tange à recomposição dos estoques. Diante de uma visão ampla quanto à distribuição do consumo dos recursos, os gestores podem melhor avaliar a seqüência lógica das mesmas, as alternativas para otimização de resultados e tempo, tanto no que tange ao processo global como no que se refere a um produto específico e ao gerenciamento ambiental.

Quantidade e qualidade das informações para decisão de preços, para implementar melhorias e fatores diferenciais em novos produtos, assim como para redirecionar cursos do sistema de elaboração dos produtos atuais, podem ser encontradas no sistema de custeio do ciclo de vida dos produtos, principalmente com detalhamento dos custos das atividades consumidas pelas tarefas de proteção ambiental.

É fato inconteste que todos os produtos começam a gerar custos para a empresa desde a fase de concepção. Os gastos com pesquisa e desenvolvimento não existiriam se não houvesse a decisão de produzir, e particularmente de produzir com qualidade ambiental adequada. Ignorar estes gastos quando se avalia o custo-beneficio de um produto desenvolvido e comercializado pela empresa significa deturpar os elementos comparados custo e beneficio -, algumas vezes de forma significativa, já que atividades de pesquisa e desenvolvimento, sob os aspectos da qualidade ambiental dos produtos e processos, consomem larga margem de recursos, fazendo com que as empresas, às vezes, otimizem a aplicação de recursos em atividades menos rentáveis.

Os gastos na área de marketing e distribuição dos produtos tiveram significativa elevação graças aos crescentes fatores concorrenciais, essencialmente no que tange à divulgação dos atributos ambientais dos produtos. As empresas têm aplicado maior volume de recursos em atividades de publicidade e propaganda de seus produtos, além da criação de fatores 
diferenciais, como, por exemplo, os selos que promovem a qualidade ambiental do produto.

A premissa da Contabilidade por Atividades, de alocar custos por atividades, oferece condições satisfatórias para a distribuição dos gastos com pesquisa e desenvolvimento e marketing, melhorando, significativamente, a qualidade das informações, no concernente aos custos efetivamente incorridos para colocar o produto no mercado, para produzi-lo, concomitantemente às informações sobre os gastos ambientais incorridos na produção do mesmo.

As condições de distribuição dos produtos também deverão merecer tratamento específico, já que devem ser realizadas de acordo com os parâmetros ambientalmente adequados.

Os custos ambientais precisam ser corretamente identificados, mensurados e informados para subsidiar o processo de gestão estratégica de custos e, conseqüentemente, a gestão econômica da empresa, como também para satisfazer às necessidades informativas dos usuários externos.

A necessidade de informações sobre a situação econômico-financeira das empresas é de fundamental importância para evidenciar a responsabilidade social efetivamente assumida pela empresa e seus impactos sobre o meio ambiente. Essas informações são preciosas para avaliar as perspectivas de continuidade e os benefícios que dela podem ser esperados.

Portanto, a continuidade das empresas está condicionada à forma de atuação de seus gestores e à sua aceitabilidade pelos usuários externos. A atuação dos gestores exige a utilização de mecanismos adequados para identificação, apuração e análise dos recursos consumidos pelo negócio. E essa aceitabilidade pelos usuários externos se dará à medida que as empresas puderem satisfazer às suas necessidades, seja no nível econômico, político, social, seja em termos ambientais. 


\section{VIII - BIBLIOGRAFIA}

ABAMEC Nacional. Apostila do Seminário Balanço Social - Participação X Responsabilidade Empresarial. São Paulo, nov. 1997.

ABTN - Associação Brasileira de Normas Técnicas. NBR 14001 - Sistemas de Gestão Ambiental - Especificação e Diretrizes para Uso. Rio de Janeiro, 1996.

ACKOFF, Russel. Planejamento Empresarial. Rio de Janeiro: Livros Técnicos e Científicos, 1975.

ADCE - Associação de Dirigentes Cristãos Empresariais. Apostila do Seminário Internacional de Balanço Social. São Paulo, abril 1980.

ANSOFF, H. Igor. A Nova Estratégia Empresarial. São Paulo: Atlas, 1990.

ANTHONY, Robert N. Contabilidade Gerencial. São Paulo: Atlas, 1974.

ANTHONY, Robert \& HEKIMIAN, James. Controle de Custos de Operações. São Paulo: Brasiliense, 1974.

ANTHONY, Robert et alii. Management Control Systems. 5a ed. EUA: Richard D. Irwin, Inc, 1984.

BERLINER, Callie \& BRIMSON, James. Cost Management for Today's Advanced Manufacturing - The CAM-I Conceptual Design. EUA: Harvard Business School Press, 1988 . 
BEUREN, Ilse Maria \& SCHÄFFER, Viviany. Custos do Ciclo de Vida do Produto: Uma Abordagem Teórica com Base na Obtenção de Vantagem Competitiva. Revista Brasileira de Contabilidade, Ano XXVI, nº 108, p. 44-49, jul/ago. 1997.

BEZERRA, Francisco Antonio Reconhecendo o Meio Ambiente como um Fator de Sobrevivência Empresarial. Anais do V Congreso Internacional de Costos. Acapulco, México, p. 799-808, 1997.

BOGNAR, Sônia Regina. Contribuição ao Processo de Determinação de Preço Sob os Aspectos de Gestão Econômica. Dissertação de Mestrado. São Paulo: FEA/USP, 1993.

BOONE, Corinne \& HOWES, Helen. Accounting for the Environment. CMA Magazine, EUA, p. 22-24, June 1997.

BRIMSON, James. Contabilidade por Atividades - Uma Abordagem de Custeio Baseado em Atividades. São Paulo: Atlas, 1996.

CAMPOS, Lucila Maria de Souza. Um Estudo para Definição e Identificação dos Custos da Qualidade Ambiental. Dissertação de Mestrado. Florianópolis: UFSC, 1996.

CATELLI, Armando \& GUERREIRO, Reinaldo. GECON Sistema de informação de Gestão Econômica: Uma Proposta para Mensuração Contábil do Resultado das Atividades Empresarias. Boletim Interamericano da Asociación Interamericana de Contabilidad, nov. 1992.

CATELLI, Armando \& GUERREIRO, Reinaldo. GECON Gestão Econômica: Administração por Resultados Econômicos para Otimização da Eficácia Empresarial. Anais do XVII Congresso Argentino de Profesores Universitários de Costos. $l^{a s}$. Jornadas Iberoamericanas de Costos y Contabilidad de Gestion, Argentina: out. 1994. 
CATELLI, Armando \& GUERREIRO, Reinaldo. Uma Análise Crítica do Sistema 'ABC' Activity Based Costing. Anais do XVII Jornada de Contabilidade, Economia e Administração do Cone Sul. Santos, out. 1994.

CAVENAGHI, Vagner. O Modelo de Gestão Econômica Aplicado à Área de Produção: Uma Contribuição da Controladoria ao Novo Paradigma da Produção. Dissertação de Mestrado. São Paulo: FEA/USP, 1996.

CICA - The Canadian Institute of Chartered Accountants. Environmental Costs $e$ Liabilities: Accounting e Financial Reporting Issues. Research Report. Canadá, 1992.

CRUZ, Rozany I. Uma Contribuição à Definição de um Modelo Conceitual para a Gestão Econômica. Dissertação de Mestrado. São Paulo: FEA/USP, 1991.

CUESTA, Carmen Fernández. Control Económico de los Residuos Empresariales. Anais do V Congreso Internacional de Costos. p. 761-780, Acapulco, México, 1997.

DE LUCA, Márcia Martins Mendes. A Contribuição da Demonstração do Valor Adicionado no Processo de Mensuração do PIB e em Algumas Análises Macroeconômicas. Tese de Doutoramento. São Paulo: FEA/USP, 1996.

DEMING, Willian Edwards. Qualidade: A Revolução da Administração. Rio de Janeiro: Marques Saraiva, 1990.

DONAIRE, Denis. Gestão Ambiental na Empresa. São Paulo: Atlas, 1995.

DOWELL, Silvia Ferreira Mac \& CORRÊA, Silva Fazzolari. Meio Ambiente e o Mercado Financeiro. Anais do IV Encontro Nacional Sobre Gestão Empresarial e Meio Ambiente. FIA-FEA/USP \& CEAMA/EAESP/FGV. São Paulo: Plêiade, nov. 1997. 
EPELBAUM, Michel. Sistemas de Gestão Ambiental ISO 14000: Mudando a Postura Reativa. Anais do IV Encontro Nacional Sobre Gestão Empresarial e Meio Ambiente. FIA-FEA/USP \& CEAMA/EAESP/FGV. São Paulo: Plêiade, nov. 1997.

FASB - Financial Accounting Statement Board - Emerging Issues Task Force. Capitalization of Costs to Treat Environmental Contamination. Issue 90-8. EUA, jul. 1990.

FOLHA DE SÃO PAULO. Balanço Verde. São Paulo: Painel S/A, Caderno Dinheiro, 25/09/97, p. 2.

GILBERT, Michael J. BS7750 (FUTURA ISO 14001) - Sistema de Gerenciamento Ambiental. $1^{\text {a }}$ ed. São Paulo: IMAM, 1995.

GLAUTIER, M.W.E \& UNDERDOWN, B. Accounting Theory. $5^{\mathrm{a}}$ ed. Great Britain: Pitman Publishing, 1995.

GOLDDRATT, Eliahu M. \& FOX, Robert E. A Síndrome do Palheiro: Garimpando Informações num Oceano de Dados. $2^{\mathrm{a}}$ ed. São Paulo: Educador, 1992.

GONÇALVES, E. Lima. Balanço Social da Empresa na América Latina. São Paulo: Pioneira, 1980.

GUERREIRO, Reinaldo. Modelo Conceitual de Sistema de Informação da Gestão Econômica: Uma Contribuição à Teoria da Comunicação da Contabilidade. Tese de Doutoramento. São Paulo: FEA/USP, 1989.

GUERREIRO, Reinaldo. Mensuração do Resultado Econômico. Caderno de Estudo da FIPECAFI. nº 3, São Paulo: FEA/USP, set. 1991. 
GUERREIRO, Reinaldo. Um Modelo de Sistema de Informação Contábil para Mensuração do Desempenho Econômico das Atividades Empresariais. Anais da XIX Conferência Intermericana de Contabilidade. Buenos Aires: out. 1991.

GUTSCHELHOFER, Alfred \& ROBERTS, Hanno. Anglo-Saxon e German Life-Cycle Costing. The International Journal of Accounting. Illinois. v. 32, n. 1, p. 23-44, 1997.

HAMNER, Burt \& STINSON, Christopher. Managerial Accounting and Environmental Compliance Cost. Journal of Cost Management. v. 9, n. 2, p. 4 - 10, Summer 1995.

HENDRIKSEN, Elson S. \& VAN BREDA, Michael F. Accounting Theory. 5a ed. EUA: Irwin Inc, 1992.

HOJDA, Ricardo Gross. ISO 14001 - Sistemas de Gestão Ambiental. Dissertação de Mestrado. São Paulo: POLI/USP, 1997.

HORnGREN, Charles. T. Contabilidade de Custos: Um Enfoque Administrativo. São Paulo: Atlas, 1978.

HORNGREN, Charles T. \& FOSTER, George. Cost Accounting - A Managerial Emphasis. $7^{\mathrm{a}}$ ed. EUA: Prentice-Hall Inc, 1991.

HUGHES, Susan B. \& WILliS, David M. How Quality Control Concepts Can Reduce Environmental Expenditures. Journal of Cost Management. v. 9, n. 2, p. 15-19, Summer 1995.

IBRACON - Instituto Brasileiro de Contadores. Princípios Contábeis - Normas e Procedimentos de Auditoria. $2^{\mathrm{a}}$ ed. São Paulo, 1994. 
IBRACON - Instituto Brasileiro de Contadores. Normas e Procedimentos de Auditoria NPA 11 - "Balanço e Ecologia”. 1996.

IFAC - International Auditing Practices Committee. The Consideration of Environmental Matters in the Audit of Financial Statements. Exposure Draft, september, 1997.

IMA - Institute of Management Accountants. Practices e Techniques: Implementing Corporate Environmental Strategies. Statement n ${ }^{\circ}$ W, July 1995.

IMA - Institute of Management Accountants. Tools e Techniques of Environmental Accounting for Business Decisions. Statement nº 4Z, July 1996.

IUDÍCIBUS, Sérgio de. Teoria da Contabilidade. 3 ed. São Paulo: Atlas, 1993.

IUDÍCIBUS, Sérgio de, et alii. Manual de Contabilidade das Sociedades Por Ações. $4^{\mathrm{a}}$ ed. São Paulo: Atlas, 1995.

JOHNSON, H. Thomas \& KAPLAN, Robert S. A Relevância da Contabilidade de Custos. $2^{a}$ ed. Rio de Janeiro: Campus, 1996.

JÖHR, Hans. O Verde é Negócio. $3^{\text {a }}$ ed . São Paulo: Saraiva, 1994.

JURAN, J.M. A Qualidade Desde o Projeto - Os Novos Passos para o Planejamento da Qualidade em Produtos e Serviços. 3ª ed. São Paulo: Pioneira, 1997.

JURAN, J.M. \& GRYNA, Frank. Controle da Qualidade - Conceitos, Políticas e Filosofia da Qualidade. São Paulo: Makron Books, v.1, 1991.

KINLAW, Dennis C. Empresa Competitiva \& Ecológica - Desempenho Sustentado na Era Ambiental. São Paulo: Makron Books, 1997. 
KITE, Devaun. Capital Budgeting: Integrating Environmental Impact - Managerial Accounting e Environmental Compliance Costs. Journal of Cost Management. v. 9, n. 2 , p. $11-14$, Summer 1995.

KRUGLIANSKAS, Isak. Influência da Gestão Empresarial e Tecnológica no Desempenho Ambiental da Empresa: O Caso da Rhodia. Anais do XIX Simpósio de Gestão da Inovação Tecnológica. São Paulo: FIA-FEA-USP, Out. 1996.

LUCENA, Maria Diva da Salete. Avaliação de Desempenho. São Paulo: Atlas, 1994.

MARGARIDO, Antonio C. et alii. "Total Quality Environmental Management” e a Atualização Tecnológica. Anais do XIX Simpósio de Gestão da Inovação Tecnológica. São Paulo: FIA/FEA-USP, p. 1652 - 1664, 1996.

MARTINS, Eliseu. Balanço Social - idéia que merece permanecer. Jornal Gazeta Mercantil,18/09/97, p. A-3.

MARTINS, Eliseu. Contabilidade de Custos. $5^{\text {a }}$ ed. São Paulo: Atlas. 1996.

MILLER, John A. Implementing Activity-Based Management in Daily Operations. EUA: John Wiley \& Sons Inc, 1996.

MILNE, Markus J. On Sustainability; the Environment e Management Accounting. Management Accounting Research. EUA, v.7, p. 135-161, 1996.

MINISTÉRIO DO MEIO AMBIENTE, DOS RECURSOS HIDRÍCOS E DA AMAZÔNIA LEGAL. Exposição de Motivos n $n^{o}$ 12. 14/11/95, DOU, 16/11/95. 
MORAES, Luis Antônio Molento, et alii. Gestão de Projetos: Ciclo de Vida e uso de Técnicas de Apoio à Decisão. Anais do XIX Simpósio de Gestão da Inovação Tecnológica. São Paulo: FIA/FEA-USP, out. 1996.

MORSE, Wayne J. \& ROTH, Harold. Cost Accounting - Processing, Evaluating and Using Cost Data. 3a ed. EUA: Addison-Wesley Publishing Company, 1986.

NAKAGAWA, Masayuki. Introdução à Controladoria: Conceitos, Sistemas, Implementação. São Paulo: Atlas, 1993.

NAKAGAWA, Masayuki. Gestão Estratégica de Custos - Conceito, Sistemas e Implementação - JIT/TQC. São Paulo: Atlas, 1991.

NOGUEIRA, Clayton C. Contribuição ao Estudo da Decisão de Preços: Proposta de um Modelo de Decisão de Preços do Ponto de Vista do Resultado Econômico. Dissertação de Mestrado. São Paulo: FEA/USP, 1993.

ORSSATO, Mara Taisa et alii. Os Custos das Políticas Ambientais são Custos, que não Agregam Valor, para as Empresas? Anais do V Congreso Internacional de Costos. Acapulco, México, p. 809-820, 1997.

PELEIAS, Ivan Ricardo. Avaliação de Desempenho: Um Enfoque de Gestão Econômica. Dissertação de Mestrado. São Paulo: FEA/USP, 1992.

PORTO, Geciane Silveira \& ANDREASSI, Tales. Análise de Modelo de Gestão Ambiental: Um estudo Comparativo. ANAIS do I SEMEAD. São Paulo: FEA/USP, p. 197-216, 1996. 
QUERINI, Giulio. Strumenti Giuridici ed Economici per la Eco-Compatibilitá Degli Investimenti nella Unione Europea. Apostila, palestra, São Paulo: FEA/USP, mar. 1997.

RANGAMATHAN, Janet \& DITZ, Daryl. Environmental Accounting: a Tool for Better Management. Management Accounting. EUA: p. 38-40, fev. 1996.

REIS, Maurício J.L. ISO 14.000: Gerenciamento Ambiental: Um Novo Desafio para sua Competitividade. Rio de Janeiro: Qualitymark Editora, 1995.

RIBEIRO, Maisa de Souza. Contabilidade e o Meio Ambiente. Dissertação de Mestrado. São Paulo: FEA/USP, 1992.

RIBEIRO, Maisa de Souza. Qualidade para o Futuro. Revista ORIGINALL. São Paulo: Origin C \& P Brasil, Ano III, n. 14, nov/dez. 1995.

RIBEIRO, Maisa de Souza. A Informação como Instrumento de Contribuição da Contabilidade para a Compatibilização do Desenvolvimento Econômico e a Preservação do Meio Ambiente. Boletim IBRACON. São Paulo, setembro 1995.

ROBLES JUNIOR, Antonio. Contribuição ao Estudo da Gestão e Mensuração de Custos da Qualidade, no Contexto da Gestão Estratégica de Custos. Tese de Doutorado. São Paulo: FEA/USP, 1992.

SANVICENTE, Antonio Zoratto \& SANTOS, Celso da Costa. Orçamento na Administração de Empresas: Planejamento e Controle. $2^{\mathrm{a}}$ ed. São Paulo: Atlas, 1987.

SHANK, John K. \& GOVINDARAJAN, Vijay. A Revolução dos Custos - Como Reinventar e Redefinir Sua Estratégia de Custos para Vencer em Mercados Crescentemente Competitivos. $2^{\mathrm{a}}$ ed. Rio de Janeiro: Campos, 1997. 
SILVA NETO, José Moreira da. Processo de Mensuração de Desempenho Ambiental PMDA. Uma Abordagem Estratégica aos Custos e Desempenho de Empresa no Contexto do Meio Ambiente. Anais do V Congreso Internacional de Costos. Acapulco, México, p. 781-797, 1997.

TINOCO, João Eduardo Prudêncio. Balanço Social - Uma Abordagem Sócio-Econômica da Contabilidade. Dissertação de Mestrado. São Paulo: FEA/USP, 1980.

TINOCO, João Eduardo Prudêncio. Contribuição ao Estudo da Contabilidade Estratégica de Recursos Humanos. Tese de Doutoramento. São Paulo: FEA/USP, 1996.

TINOCO, João Eduardo Prudêncio. Balanço Social e Contabilidade de Recursos Humanos. Apostila do Seminário "Balanço Social - Uma Idéia Viva”. $3^{\circ}$ grupo. São Paulo: JCA Treinamentos e FIPECAFI-FEA/USP. Dez. 1997.

UN-ISAR - Intergovernamental Working Group of Experts on International Standards of Accounting e Reporting. Accounting e Reporting for Environmental Liabilities e Costs within the existing Financial Reporting Framework. Geneve: Draft. July, 1997.

VALLE, Cyro Eyer do. Qualidade Ambiental: O Desafio de Ser Competitivo Protegendo o Meio Ambiente. São Paulo: Pioneira, 1995.

VIEIRA, Celso Vanderlei. Uma Contribuição ao Estudo da Controlabilidade nas Organizações. Dissertação de Mestrado. São Paulo: FEA/USP, 1991.

WERKMEISTER, Werner von Bischhoffshausen. Costos para la Gestión Ambiental. Anais do V Congreso Internacional de Costos. Acapulco, México, p. 821-832, 1997. 